\title{
METABOLIC STUDIES IN PARALYTIC ACUTE ANTERIOR POLIOMYELITIS. IV. EFFECTS OF TESTOSTERONE PROPIONATE AND ESTRADIOL BENZOATE ON CALCIUM, PHOSPHORUS, NITROGEN, CREATINE AND ELECTROLYTE METABOLISM ${ }^{1}$
}

\author{
By G. DONALD WHEDON ${ }^{2}$ AND EPHRAIM SHORR $\dagger$ \\ WITH THE TECHNICAL ASSISTANCE \\ oF VINCENT TOSCANI AND ESTELLE STEVENS
}

\begin{abstract}
(From the Russell Sage Institute of Pathology, the Department of Medicine, Cornell University Medical College, and the New York Hospital, New York, N. Y.)
\end{abstract}

(Submitted for publication July 27, 1956; accepted November 26, 1956)

The first two papers in this series $(1,2)$ described various marked metabolic derangements resulting from paralytic acute anterior poliomyelitis, particularly those involving nitrogen, creatine, calcium and phosphorus metabolism. The third paper (3) related the results of an attempt to minimize these extensive derangements by use of the slowly oscillating bed. The present paper reports results of an effort to modify the disordered metabolism of paralytic poliomyelitis by means of gonadal steroid hormones. These steroids have been shown in various clinical states to be effective in reducing the excretion of nitrogen, calcium and phosphorus and in favoring the positive balance of these elements. Because of these effects, it seemed reasonable to investigate whether or not gonadal steroids would act in a similar manner in a disease following which development of muscle and bone atrophy is prominent.

More specifically, the suggestion that gonadal steroids might have value in paralytic poliomyelitis arose from a variety of studies and observations. The protein anabolic effects of androgens have been summarized by Kochakian (4). Papanicolaou and Falk (5) were evidently the first to show that testosterone administration would bring about hypertrophy of the general musculature, indicating that the retained protein was stored in muscle. The effects of androgens on calcium metabolism in post-menopausal and senile osteoporosis have been summarized by Albright and Reifenstein $(6,7)$. They and others $(8-11)$ have

\footnotetext{
1 Aided by a grant from the National Foundation for Infantile Paralysis.

2 Present address: National Institute of Arthritis and Metabolic Diseases, National Institutes of Health, Bethesda, Maryland.

† Died, January 6, 1956.
}

shown the effectiveness of androgens in the osteoporosis of Cushing's syndrome. Presumably androgens act by increasing the amount of protein osteoid matrix, essential for bone formation. Estrogen administration has been shown to be useful in postmenopausal osteoporosis $(12,13)$, in the osteoporosis of acromegaly (14) and in osteoporosis associated with Paget's disease (15). Less effective than androgens in enhancing protein deposition, estrogens are thought to act by stimulating osteoblasts to lay down more protein matrix.

The effects of both types of gonadal hormones on the skeleton of animals have been extensively studied and summarized by Gardner and Pfeiffer (16). A study particularly related to the present one is that of Armstrong, Knowlton, and Gouze (17) in which disuse atrophy of the skeleton was brought about in mature rats by severing the brachial plexus; estradiol in modest doses was found generally to prevent the atrophy whereas testosterone did not, although only very large doses of the latter steroid were given.

\section{PROCEDURE}

The general plan, procedure, clinical care and diets employed in these studies were outlined in the first paper in this series (1). The present report is based on the data of seven patients (D.A., J.C., R.W., F.S., C.R., J.W. and R.V.K.), all of whom were studied on the Metabolism Ward where closely controlled balance studies were carried out. J.W. and R.V.K. were females and the others males. Changes in diet, physical therapy or activity of the patients were in nearly all instances made not less than two weeks prior to and two to four weeks following a course of androgen or estrogen in order to provide suitable control periods before and after the administration of these hormonal agents. The relatively slow progress of physical improvement in these extensively paralyzed patients made this control possible. 
The hormonal preparations used were testosterone propionate, given intramuscularly in doses of 25 and 50 mgm. daily, and alpha-estradiol benzoate (Progynon-B), given intramuscularly in doses of 1.66 and $3.32 \mathrm{mgm}$. $(10,000$ and 20,000 rat units) daily. Testosterone propionate alone was given during various phases of the disease in eight studies for periods ranging from 12 to
42 days. Estradiol benzoate was given alone in two studies during the convalescent phase, for 18 and 30 days each. The two hormones were given concurrently (in separate syringes) in six studies for periods of 12 to 36 days. Four patients were given combined testosterone and estradiol at one time and testosterone alone at another so that in their data comparison was possible of

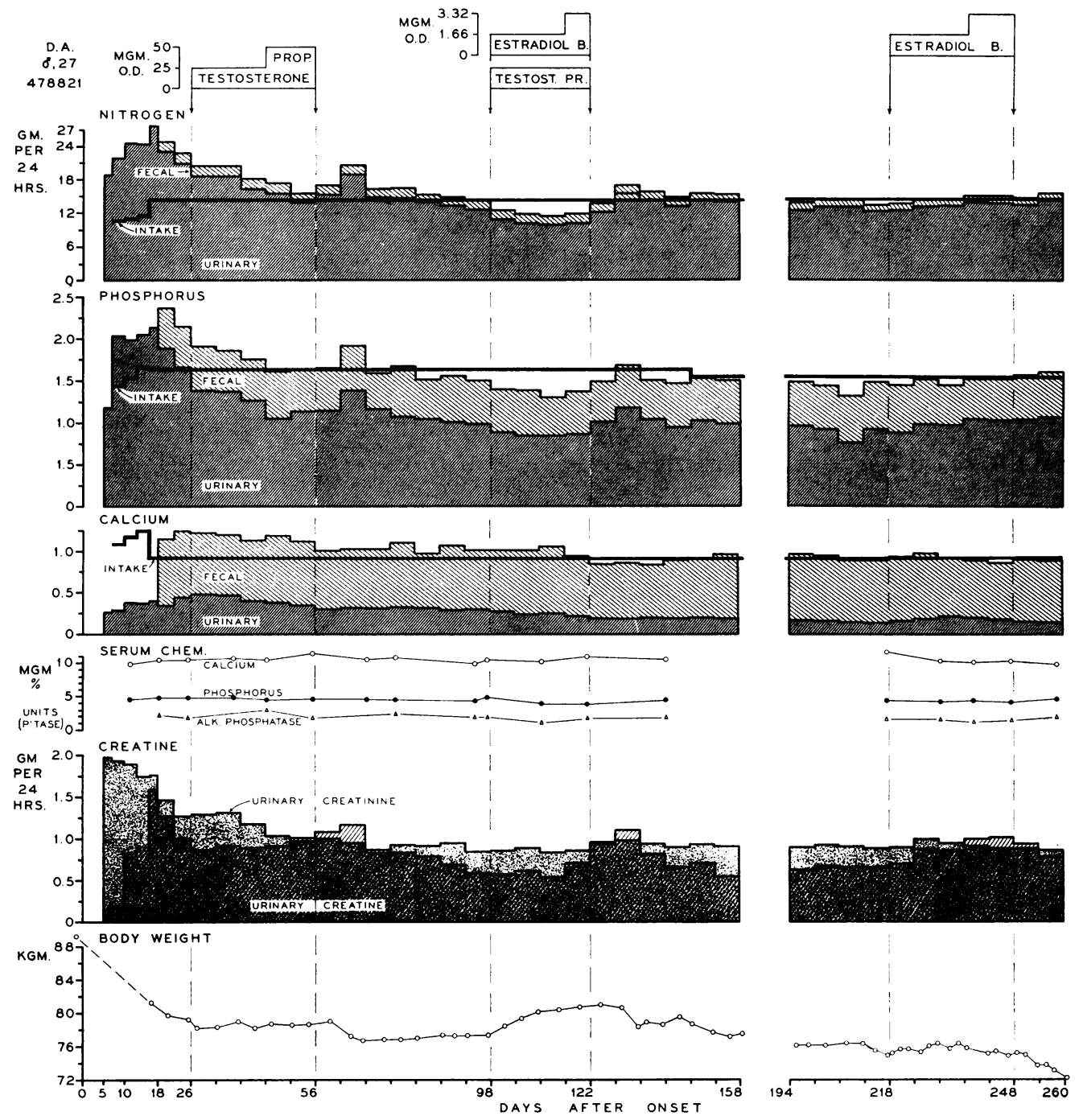

Fig. 1. Metabolic Data on Patient D.A., 27-Year-Old Male, during the First Nine Months after Onset of Paralytic Acute Anterior Poliomyelitis, Showing the Effects of Testosterone Propionate, Combined Steroid and Estradiol Benzoate Given during the Early, Mid and Late Convalescent Phases, Respectively

The nitrogen, phosphorus and calcium data are charted with the intake and output both plotted upward from the base-line and urinary output on the bottom in order to portray clearly the changes in the urinary excretion of these elements as well as the changes in balance. The ordinate scales for nitrogen and phosphorus are arranged in the ratio of 1 gram of phosphorus to 15 grams of nitrogen; the ordinate scales of calcium and phosphorus are arranged in the ratio of $1: 1$. Urinary creatine and creatinine are plotted together, the creatinine in stippled tone overlapped by creatine in crosshatched tone. 

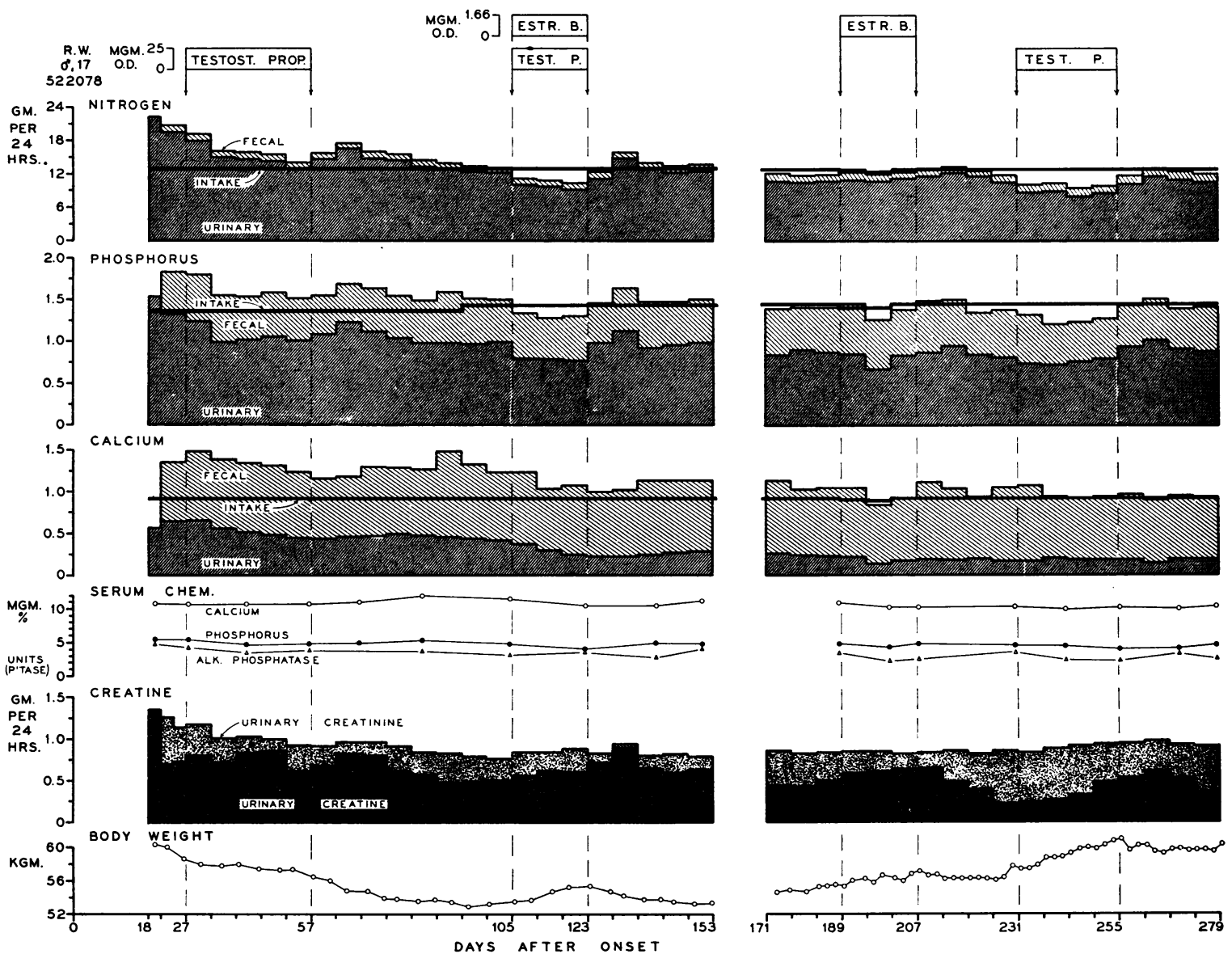

Fig. 2. Metabolic Data on Patient R.W., 17-Year-Old Male, during the First Nine Months after Onset of Paralytic Acute Anterior Poliomyelitis, Showing the Effects of Testosterone Propionate Given During the Early Convalescent and Chronic Phases, and of Combined Steroid and Estradiol Benzoate Given during the Convalescent Phase

Explanation of construction of chart is in legend for Figure 1.

combined administration of the hormones with those of androgen alone.

\section{METHODS}

The methods for analysis of urine, stool and serum for the various chemical constituents have been given in the first two papers of this series $(1,2)$. Metabolic balance studies were carried out in six-day periods. The methods for measuring girth of thighs and calves and strength of muscle groups were given in the first paper (1). Tests of basal metabolic rate were performed every 10 to 14 days by the method of Benedict and Roth (18). Measurements of skin temperature were made in two patients (F.S. and C.R.) by the method described in the third paper of this series (3).

Definitions and abbreviations. In this paper the various phases of illness are defined as follows: early convalescent, from the third to eighth week after onset of illness; convalescent, second through sixth month; and chronic, after the sixth month. The following abbreviations are employed: t.p. = testosterone propionate; e.b. = estradiol benzoate; and in Table III, Comb. = Combined testosterone propionate-estradiol benzoate administration.

\section{RESULTS}

\section{Observations of Metabolic Constituents}

A. Effects on nitrogen, creatine, glycocyamine, body weight, calcium, phosphorus, citric acid, 17-ketosteroids and serum calcium, phosphorus and alkaline phosphatase

1. Effects of testosterone propionate administration.

a. Early convalescent phase. By the fourth week after onset of illness the high urinary ni- 
trogen excretion previously described (1) had passed its peak and was declining, and urinary creatine excretion was also beginning to recede from high levels. Urinary calcium excretion was approaching a peak, and, from the data of other patients who were not given gonadal steroids, would be expected to maintain a high plateau level for many weeks (2). Testosterone propionate was given to two male patients, D.A. and R.W., beginning at the 27 th and 28th days after onset of illness, respectively (Figures 1 and 2). Each received the steroid for 30 days, D.A., 25 mgm. daily for the first 18 days and then $50 \mathrm{mgm}$. daily, and R.W., $25 \mathrm{mgm}$. daily throughout.

During the month's administration of t.p. to these two patients, urinary nitrogen excretion steadily decreased (from 20.0 gm. per day to 13.8 gm. per day in D.A. and from $18.4 \mathrm{gm}$. per day to 12.9 gm. per day in R.W.), and the nitrogen balance approached equilibrium. The rate of decline, however, was not greater than that occurring during the week just prior to the administration of t.p. Evidence for an effect of the hormones appeared in a rebound rise in urinary nitrogen (to $18.8 \mathrm{gm}$. per day in D.A. and to $16.6 \mathrm{gm}$. per day in R.W.) during the 12 days immediately following hormone administration. Urinary creatine excretion during t.p. administration did not fall but fluctuated about initial levels ( $1.00 \mathrm{gm}$. per day in D.A. and $0.725 \mathrm{gm}$. per day in R.W.) ; other patients not on t.p. showed a gradual decline in creatinuria during this phase of the disease. When testosterone was stopped, a distinct increase in creatinuria was noted. Urinary glycocyamine, the

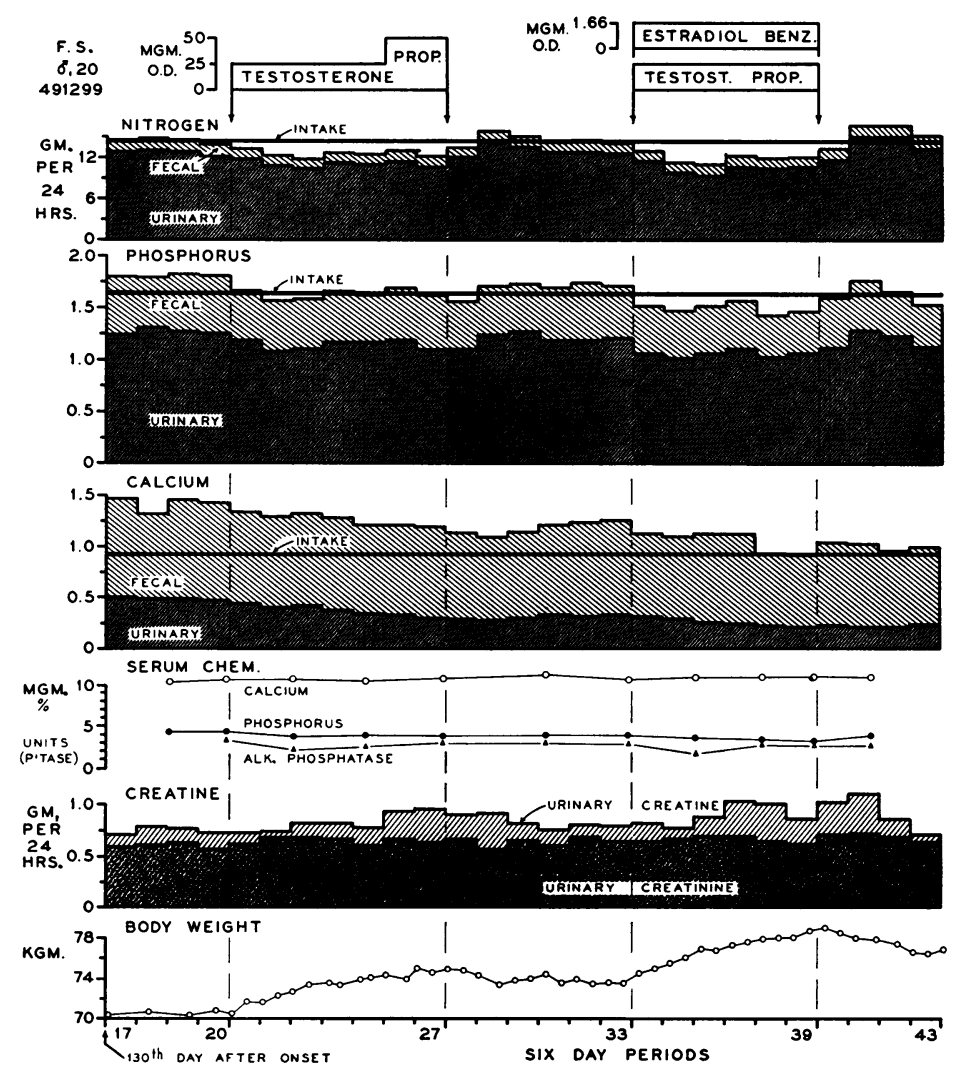

Fig. 3. Metabolic Data on Patient F.S., 20-Year-Old Male, during the Fifth through Tenth Months after Onset of Paralytic Acute Anterior Poliomyelitis, Showing the Effects of Testosterone Propionate and Combined Steroid Given during the Late Convalescent-Chronic Phase

Explanation of construction of chart is in legend for Figure 1. As indicated, urinary creatine in this patient exceeded urinary creatinine. 
known precursor of creatine, was determined in an effort to obtain information suggestive of changes in creatine synthesis (1); the excretion values of this substance were not significantly altered. Urinary creatinine continued to fall slowly, at a rate not evidently different from that of other patients not on the hormone. Body weight, previously declining rapidly, remained fairly stable during the 30-day testosterone administration interval, then fell again rather rapidly when the hormone was stopped.

Urinary calcium excretion showed a definite decrease on testosterone, falling from 0.392 gm. per day to $0.300 \mathrm{gm}$. per day in D.A. and from 0.648 gm. per day to $0.443 \mathrm{gm}$. per day in R.W.; fecal calcium was slightly diminished. Calcium balance became less negative by nearly $0.200 \mathrm{gm}$. per day in each patient. As was usually observed in these studies, the decrease in calcium excretion continued for two metabolic balance periods (twelve days) after the hormone was discontinued. Thereafter, increases in urinary calcium were sluggish and slight so that both urinary calcium and calcium balance tended to remain at a new level close to that reached at the conclusion of hormone administration. Phosphorus excretion changed closely with nitrogen. Urinary citric acid was measured because of its importance for the solubility of calcium $(2,19)$; in the case of D.A., citric acid varied little from the control level of $0.364 \mathrm{gm}$. per day, but in R.W. it fell from $0.381 \mathrm{gm}$. per day to an average of $0.209 \mathrm{gm}$. per day during t.p. Except for a fall of $0.5 \mathrm{mgm}$. per cent in serum phosphorus in R.W., no changes occurred in the serum chemistries. Urinary 17-ketosteroids increased from 9.1 to $28.0 \mathrm{mgm}$. per day in D.A. but only from 11.5 to $15.9 \mathrm{mgm}$. per day in R.W. The increase in dosage from $25 \mathrm{mgm}$. to $50 \mathrm{mgm}$. of t.p. daily in D.A. brought about no detectable modification in any of the changes in metabolic function described.

b. Convalescent phase. Testosterone propionate was given to two male patients, F.S. and C.R., five months after onset of their disease. Each was given $25 \mathrm{mgm}$. daily for 30 days, then 50 mgm. for the next 12 days (Figures 3 and 4 ). In these two individuals in whom two-thirds or more of their original total muscle mass was without innervation, excretion of most metabolic constituents was fairly stable by this time; nitrogen was

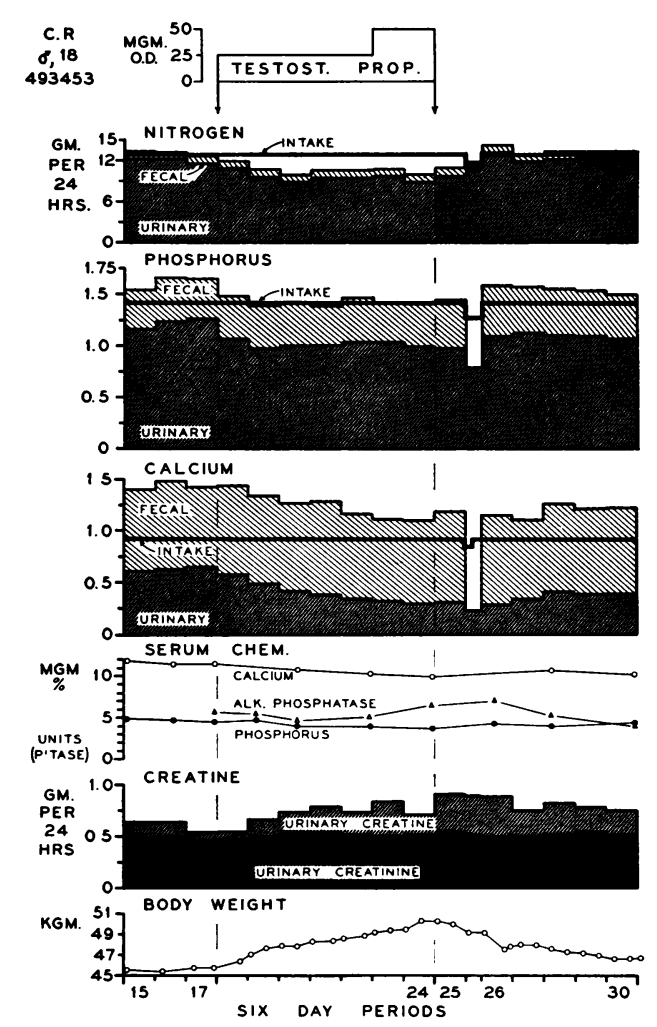

Fig. 4. Metabolic Data on Patient C.R., 18-YeakOld Male, during the Fifth through Eighth Month after Onset of Paralytic Acute Anterior Poliomyelitis, Showing the Effects of Testosterone Propionate Given during the Convalescent Phase

Stools were not collected for a three-day interval between metabolic periods 25 and 26 ; patient had an intercurrent aspiration pneumonitis (see case summary). Explanation of construction of chart is in legend for Figure 1. As indicated, urinary creatine in this patient exceeded urinary creatinine.

virtually in balance, creatinuria was constant (approximately at $0.750 \mathrm{gm}$. per day for F.S. and $0.600 \mathrm{gm}$. per day for C.R.), urinary calcium excretion was at a steady high level $(0.480 \mathrm{gm}$. per day for F.S. and $0.650 \mathrm{gm}$. per day for C.R.) and calcium balance was negative to the extent of approximately $0.500 \mathrm{gm}$. per day in each patient.

Testosterone propionate brought about a marked retention of nitrogen. When retention became maximal during the third week of hormone administration, daily positive nitrogen balance was $2.57 \mathrm{gm}$. for F.S. and $2.70 \mathrm{gm}$. for C.R.; the average daily storage throughout with respect to the control base-line (comparing the daily balances of control and experimental periods) was 1.68 and 
TABLE I

Summary of principal metabolic changes resulting from administration of testosterone propionate and estradiol benzoate given singly to five patients *

\begin{tabular}{|c|c|c|c|c|c|c|c|c|c|c|c|c|}
\hline \multirow{4}{*}{$\begin{array}{l}\text { Patient } \\
\text { D. A. }\end{array}$} & \multirow{2}{*}{$\begin{array}{l}\text { Steroid } \\
\text { and daily } \\
\text { dose }\end{array}$} & \multirow{2}{*}{$\begin{array}{l}\text { No. of } \\
\text { days }\end{array}$} & \multirow[b]{2}{*}{$\begin{array}{c}\text { Initial } \\
\text { day }\end{array}$} & \multirow{2}{*}{$\begin{array}{l}\text { N bal. } \\
\text { change } \\
\text { (Control } \\
\text { to a v. on } \\
\text { steroid) }\end{array}$} & \multirow{2}{*}{$\begin{array}{c}\text { Total } \\
\text { N } \\
\text { storage }\end{array}$} & \multirow{2}{*}{$\begin{array}{l}\text { Rebound } \\
\text { loss, } \\
\% \text { of } \\
\text { slorage }\end{array}$} & \multirow{2}{*}{$\begin{array}{c}\text { Creati- } \\
\text { nuria } \\
\text { change } \\
\text { (Control } \\
\text { to max.) }\end{array}$} & \multirow{2}{*}{$\begin{array}{l}\text { Glyco- } \\
\text { cyamine } \\
\text { change }\end{array}$} & \multirow{2}{*}{\multicolumn{2}{|c|}{$\begin{array}{c}\begin{array}{c}\text { Urine calcium } \\
\text { change }\end{array} \\
\begin{array}{l}\text { (Control to } \\
\text { maximum†) }\end{array}\end{array}$}} & \multicolumn{2}{|c|}{$\begin{array}{c}\text { Calcium balance } \\
\text { change }\end{array}$} \\
\hline & & & & & & & & & & & $\begin{array}{l}\text { (Control } \\
\text { to max. } \dagger)\end{array}$ & $\begin{array}{l}(\text { Control } \\
\text { to av. } \dagger)\end{array}$ \\
\hline & $m g m$. & & & $g m . / d a y$ & $g m$. & & $g m . / d a y$ & $\%$ & $g m . / d a y$ & $\%$ & $g m . / d a y$ & gm./day \\
\hline & T.p., 50 & $\begin{array}{l}10 \\
12\end{array}$ & 21 & +4.34 & & & +0.007 & 0 & -0.092 & -23 & +0.180 & +0.065 \\
\hline R. W. & T.p., 25 & 30 & 28 & +3.52 & & & +0.131 & 0 & -0.205 & -32 & +0.195 & +0.061 \\
\hline F.S. & T.p., 25 & 30 & 155 & & & & & & & & & \\
\hline & T.p., 50 & 12 & & +1.68 & 70.6 & 13 & +0.200 & & -0.202 & -43 & +0.325 & +0.223 \\
\hline C. R. & T.p., 25 & 30 & 158 & & & & & & & & & \\
\hline & T.p., 50 & 12 & & +2.33 & 98.0 & 8 & +0.241 & & -0.354 & -56 & +0.352 & +0.210 \\
\hline R. W. & T.p., 25 & 24 & 232 & +2.24 & 53.8 & 4 & +0.178 & +25 & -0.035 & -19 & +0.063 & +0.038 \\
\hline R.V.K. & T.p., 50 & 18 & 615 & +2.35 & 42.3 & 7 & +0.154 & & -0.030 & -23 & +0.092 & +0.092 \\
\hline D. A. & $\begin{array}{l}\text { E.b., } 1.66 \\
\text { E.b., } 3.32\end{array}$ & $\begin{array}{l}518 \\
212\end{array}$ & 219 & -0.68 & -20.4 & & +0.349 & +90 & $\begin{array}{l}+0.061 \\
-0.005\end{array}$ & $\begin{array}{l}+41 \\
-3\end{array}$ & +0.033 & -0.002 \\
\hline R.W. & E.b., 1.66 & 618 & 190 & -0.88 & -15.8 & & +0.178 & +72 & -0.080 & -33 & +0.079 & +0.079 \\
\hline
\end{tabular}

* Total $\mathrm{N}$ storage and rebound loss not calculated where control base-line was changing rapidly.

$\dagger$ Including first two metabolic periods (12 days) after steroid discontinued.

2.33 gm., respectively. Total nitrogen storage for the six weeks was $70.6 \mathrm{gm}$. for F.S. and $98 \mathrm{gm}$. for C.R., equivalent to $5 \mathrm{lbs}$. of muscle protoplasm for F.S. and $7 \mathrm{lbs}$. for C.R. Only approximately 10 per cent of this nitrogen storage was lost during the rebound phase after testosterone was stopped.

Creatinuria remained unchanged on t.p. for 10 to 15 days, then gradually and progressively increased by approximately $0.200 \mathrm{gm}$. per day. When t.p. was discontinued, creatinuria in F.S. remained at the same elevated level for approximately 12 days and then subsided to its original value; in C.R. urinary creatine for approximately 12 days rose an additional $0.070 \mathrm{gm}$. per day, then fell back toward the control level. The glycocyamine method had not been set up at this stage of the investigation so that analyses for this constituent were not carried out in these two patients. Urinary creatinine appeared to be increased slightly in both patients, the rise amounting to $0.050 \mathrm{gm}$. per day. Body weight increased 4.3 and $4.5 \mathrm{Kg}$. in F.S. and C.R., respectively.

Urinary calcium declined on t.p. and was reduced from $0.475 \mathrm{gm}$. per day to 0.273 in F.S. and from $0.637 \mathrm{gm}$. per day to 0.283 in C.R. by the second metabolic balance period after hormone administration. Fecal calcium was virtually unchanged so that the shifts of calcium balance toward positivity were equal to the decreases in urinary calcium. As described with D.A. and R.W., there was a carry-over of the effect of t.p. on calcium for approximately twelve days after discontinuation of the hormone; thereafter, urinary calcium rose slightly and calcium balance became more negative. Urinary citric acid decreased $0.270 \mathrm{gm}$. per day in F.S. and 0.359 in C.R. A fall of $1.1 \mathrm{mgm}$. per cent occurred in C.R.'s serum phosphorus and possibly a slight rise in his alkaline phosphatase. Urinary 17-ketosteroids rose from $10.0 \mathrm{mgm}$. per day to 23.6 in F.S. and from 6.3 to 17.2 in C.R.

Increasing the dose of testosterone from 25 to $50 \mathrm{mgm}$. daily appeared to have some influence although it was difficult to be certain since the higher dosage was given for only twelve days. Urinary nitrogen and citric acid seemed to be further depressed and urinary creatine and 17ketosteroids further elevated. No change, could 
be detected in the trend of progressive decrease in calcium excretion.

c. Chronic phase. More than six months after onset testosterone propionate was given to four patients. R.W. was given $25 \mathrm{mgm}$. daily for 24 days and R.V.K. (a female) 50 mgm. daily for 18 days. Less information was obtained from the administration of $50 \mathrm{mgm}$. daily for 12 days to J.W. (a female) and $25 \mathrm{mgm}$. daily for the same interval to C.R., the latter observation without a control period following. In this phase, prior to hormone administration, excretion of all metabolic constituents was virtually unvarying. Nitrogen balance was slightly positive, and there was a persistent spontaneous creatinuria. Calcium balance was still negative in three of the four patients, in R.W. $-0.075 \mathrm{gm}$. per day at the 8th month after onset, in C.R. $-0.291 \mathrm{gm}$. per day at the 10th month and in J.W. -0.093 gm. per day at the 11th month; R.V.K. at the 21st month was in positive calcium balance, $+0.147 \mathrm{gm}$. per day.

The following data obtained in R.W. and R.V.K. (Figures 2 and 5), who were given t.p. for longer periods than the other two patients, best describe the results obtained during the chronic phase. Pronounced nitrogen retention was noted in both patients, the average daily storage with respect to control base-line being $2.24 \mathrm{gm}$. for R.W. and $2.3 .5 \mathrm{gm}$. for R.V.K. R.W.'s rebound loss of nitrogen after cessation of the hormone was only 4 per cent and R.V.K.'s 7 per cent. In both patients there was a progressive increase in urinary creatine of more than $0.150 \mathrm{gm}$. per day when t.p. was given and a brief further increase when it was stopped, the after-increase being more marked in R.W. whose paralysis was less extensive. A definite increase in urinary glycocyamine occurred in R.W. (0.110 gm. per day to 0.138$)$, but no analysis of the constituent was made in R.V.K. Urinary creatinine barely changed in R.V.K. but increased approximately $0.100 \mathrm{gm}$. per day in R.W.

Calcium excretion was not greatly affected by these rather short exposures to the administration of testosterone. The positive calcium balance in R.V.K. was raised by 0.092 gm. per day, but in R.W. the reduction in negative balance was only 0.063 gm. per day, and in both patients urinary calcium was reduced by only $0.030 \mathrm{gm}$. per day. Urinary citric acid was reduced by only $0.074 \mathrm{gm}$. per day in R.W., but in R.V.K. citric acid excretion fell from 0.776 to 0.430 gm. per day. R.W.'s serum phosphorus declined $0.6 \mathrm{mgm}$. per cent. Urinary 17 -ketosteroids increased from 15.4 to $18.9 \mathrm{mgm}$. per day in R.W. and from 8.4 to 27.2 mgm. per day in R.V.K.

In the two patients, C.R. and J.W., given t.p. for only 12 days, similar changes were found: an increase in positivity of nitrogen balance, a decrease in urinary calcium and citric acid, and a decrease in negativity of calcium balance. In C.R. a slight decrease in creatinuria was noted whereas in J.W. the more usual finding in these studies was noted, an increase in creatinuria on t.p., then a further rise following.

In all of the testosterone studies urinary phosphorus and phosphorus balance moved with the changes in nitrogen and calcium. Measured phosphorus balances agreed closely with theoretical phosphorus balances calculated on the basis of the relationship of these two elements to phosphorus in muscle and bone (20). Fecal phosphorus decreased less than $0.100 \mathrm{gm}$. per day in all instances. One other finding, quite consistent in all of the testosterone studies, was an increase in the 24hour average urinary $\mathrm{pH}$ of approximately 0.2 of a $\mathrm{pH}$ unit.

2. Effects of alpha-estradiol benzoate administration. During the late convalescent-chronic phase estradiol benzoate was given to two male patients, D.A. and R.W. D.A. received $1.66 \mathrm{mgm}$. daily for 18 days and then $3.32 \mathrm{mgm}$. for the following 12 days. R.W. received $1.66 \mathrm{mgm}$. for 18 days. At this time (sixth and seventh months after onset of illness) nitrogen balance was slightly positive and creatinuria was fairly constant $(0.464$ gm. per day for R.W. and $0.666 \mathrm{gm}$. per day for D.A.). Calcium balance was -0.109 gm. per day in R.W. and $+0.011 \mathrm{gm}$. per day in D.A.

In both patients, while on e.b. and over the first 12 days following, urinary nitrogen excretion was increased by approximately $1 \mathrm{gm}$. daily so that nitrogen balance became slightly negative. Urinary creatine promptly began to rise, the increase amounting to $0.178 \mathrm{gm}$. per day in R.W. and 0.349 gm. per day in D.A. at the time the hormone was discontinued; thereafter creatinuria did not rise further but began to subside within a few days. Glycocyamine excretion increased from 0.088 to $0.151 \mathrm{gm}$. per day in R.W. and from 0.103 to 0.196 


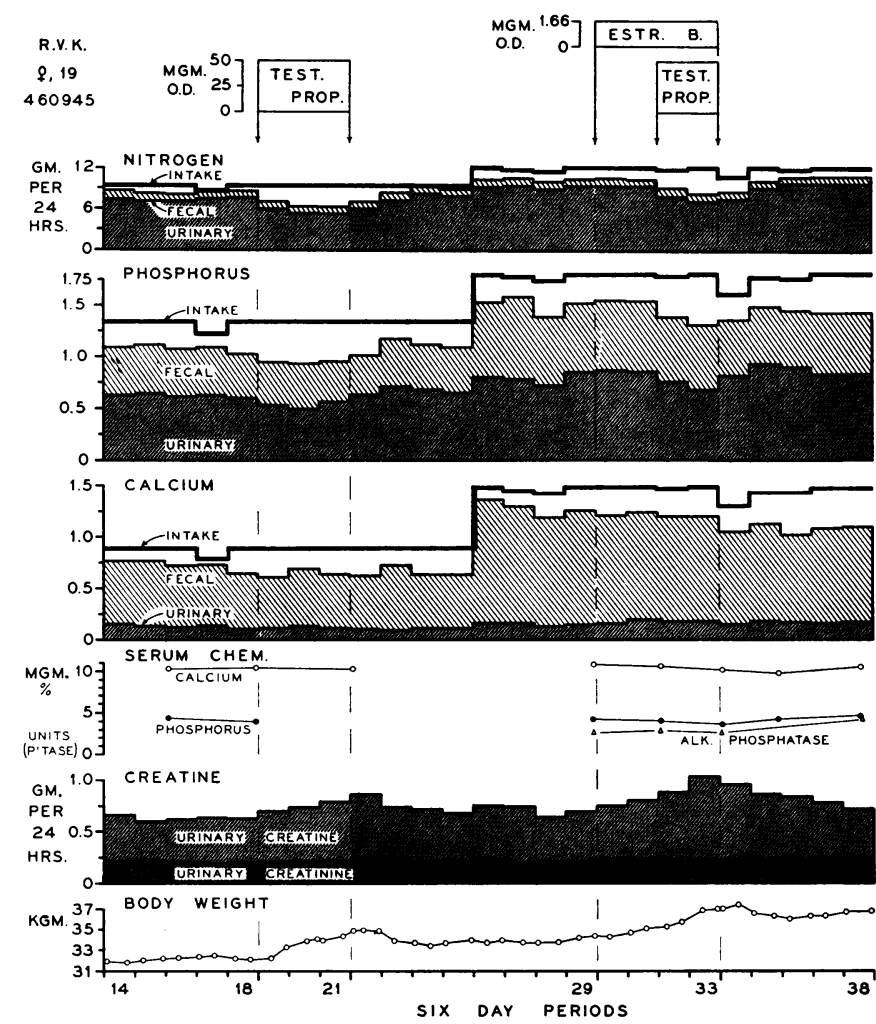

Fig. 5. Metabolic Data on Patient R.V.K., 19-Year-Old Female, during the 20Th through 24th Month after ONSET of Paralytic Acute Anterior Poliomyelitis, Showing the Effects of Testosterone Propionate and Combined Steroid Given during the Chronic Phase

Explanation of construction of chart is in legend for Figure 1. As indicated, urinary creatine in this patient exceeded urinary creatinine.

gm. per day in D.A. The latter showed a brief, unsustained rise in urinary creatinine the second week on e.b., while in R.W. no change in creatinine occurred.

Results with respect to calcium were quite different in the two patients. R.W. showed a sharp drop in urinary calcium which reached a level $0.100 \mathrm{gm}$. per day below control (average of periods on estradiol, $0.060 \mathrm{gm}$. per day less than control) and also showed a slight decrease in fecal calcium so that the reduction in negative balance was $0.079 \mathrm{gm}$. per day. Urinary calcium in D.A. showed a rise of $0.061 \mathrm{gm}$. per day on the 1.66mgm. dose, then fell toward the control level when the dose was raised. Fecal calcium was decreased, however, so that no net change occurred in calcium balance. Urinary citric acid excretion more than doubled in both patients. No changes of note occurred in the serum chemistries. Urinary 17-ketosteroid excretion decreased slightly in both patients, from an average control value of 11.9 mgm. per day to 9.3 in R.W. and from $11.0 \mathrm{mgm}$. per day to 7.3 in D.A.

In both studies measured phosphorus balances agreed closely with theoretical phosphorus balances calculated on the basis of the relationship of nitrogen and calcium to phosphorus in muscle and bone. No change occurred in the 24-hour average urinary $\mathrm{pH}$.

Assessment of the data of D.A. for the relative effects of the two dosage levels of steroid was difficult because in a number of instances increased changes occurring on the higher dose might have been due merely to a cumulative effect with time. 
The added increases in urinary nitrogen and creatine, however, did seem related to higher dosage since the excretion of these substances had become relatively stable before the amount of e.b. was increased.

3. Effects of combined androgen and estrogen administration.

a. Convalescent phase. Effects of combined hormone administration were observed in three patients during the convalescent phase. R.W. (Figure 2) during the 4th month after onset of illness was given $25 \mathrm{mgm}$. of testosterone propionate and $1.66 \mathrm{mgm}$. of estradiol benzoate daily for 18 days. During the same month D.A. (Figure 1) was given the hormones in the same dosage for 18 days, then for the following six days 3.32 mgm. estradiol benzoate plus $25 \mathrm{mgm}$. testosterone propionate. Both R.W. and D.A. had shortly before begun to sit in a wheelchair for a few hours daily, but they were still in negative nitrogen and calcium balance. The studies on J.C. are described later.

On the two hormones urinary nitrogen excretion fell and nitrogen balance shifted from -0.48 gm. per day for both R.W. and D.A. to an average of $+2.07 \mathrm{gm}$. per day for R.W. and +2.42 for D.A., the average daily storage with respect to control base-line being 2.55 and $2.80 \mathrm{gm}$. per day, respectively. Rebound loss, however, was 37 per cent and 27 per cent, respectively, of the total amounts stored. Creatinuria rose promptly and progressively in R.W., from $0.490 \mathrm{gm}$. per day to 0.608 , but in D.A. decreased by $0.148 \mathrm{gm}$. per day during the first 18 days, then rose above the control level coincident with increase in the dose of e.b. In both patients creatinuria rose even higher when the hormones were discontinued. Urinary. glycocyamine excretion was increased approximately 50 per cent in both patients, from 0.083 to $0.134 \mathrm{gm}$. per day in R.W. and from 0.094 to 0.152 gm. per day in D.A. Urinary creatinine rose slightly; in D.A. this occurred after the hormones were stopped.

Urinary calcium decreased substantially in both patients, in R.W. from $0.429 \mathrm{gm}$. per day to a low of $0.226 \mathrm{gm}$. per day during the second metabolic balance period after the hormones were stopped and in D.A. from $0.298 \mathrm{gm}$. per day to 0.181 , also during the second period following. Fecal calcium was reduced in both patients, but it is doubt-

TABLE II

Summary of principal metabolic changes resulting from administration of testosterone propionate and estradiol benzoate combined given to five patients*

\begin{tabular}{|c|c|c|c|c|c|c|c|c|c|c|c|c|}
\hline \multirow{4}{*}{$\begin{array}{l}\text { Patient } \\
\text { D. A. }\end{array}$} & \multirow{4}{*}{ 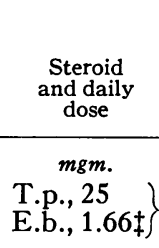 } & \multirow{4}{*}{$\begin{array}{c}\begin{array}{c}\text { No. of } \\
\text { days }\end{array} \\
24\end{array}$} & \multirow{4}{*}{$\begin{array}{c}\frac{\text { Initial }}{\text { day }} \\
99\end{array}$} & \multirow{4}{*}{$\begin{array}{c}\begin{array}{c}\mathrm{N} \mathrm{bal.} \\
\text { change } \\
\text { (Control } \\
\text { to av. on } \\
\text { steroid) }\end{array} \\
g m . / d a y \\
+2.89\end{array}$} & \multirow{3}{*}{$\begin{array}{c}\begin{array}{c}\text { Total } \\
\mathrm{N} \\
\text { storage }\end{array} \\
g m .\end{array}$} & \multirow{4}{*}{$\begin{array}{c}\begin{array}{c}\text { Rebound } \\
\text { loss, } \\
\% \text { of } \\
\text { storage }\end{array} \\
\\
27\end{array}$} & \multirow{4}{*}{$\begin{array}{c}\begin{array}{c}\text { Creati- } \\
\text { nuria } \\
\text { change } \\
\text { (Control } \\
\text { to max.) }\end{array} \\
\text { gm./day } \\
-0.148 \\
+0.027\end{array}$} & \multirow{4}{*}{$\begin{array}{c}\begin{array}{c}\text { Glyco- } \\
\text { cyamine } \\
\text { change }\end{array} \\
\% \\
+62\end{array}$} & \multirow{2}{*}{\multicolumn{2}{|c|}{$\begin{array}{c}\text { Urine calcium } \\
\text { change }\end{array}$}} & \multirow{2}{*}{\multicolumn{2}{|c|}{$\frac{\begin{array}{c}\text { Calcium balance } \\
\text { change }\end{array}}{}$}} \\
\hline & & & & & & & & & & & & \\
\hline & & & & & & & & & $g m . / d a y$ & $\%$ & $g m . / d a y$ & $g m . / d a y$ \\
\hline & & & & & 69.4 & & & & -0.117 & -39 & +0.162 & +0.057 \\
\hline R. W. & $\left.\begin{array}{l}\text { T.p., } 25 \\
\text { E.b., 1.66 }\end{array}\right\}$ & 18 & 106 & +2.55 & 45.9 & 37 & +0.118 & +61 & -0.203 & -47 & +0.274 & +0.208 \\
\hline \multirow[t]{2}{*}{ J. C. } & \multirow{2}{*}{$\left.\begin{array}{l}\text { T.p., } 25 \\
\text { T.p., } 25 \\
\text { E.b., 1.66 }\end{array}\right\}$} & 18 & 70 & +3.67 & & & -0.325 & +31 & & & & \\
\hline & & 18 & & +4.46 & & & -0.110 & +6 & -0.195 & -39 & +0.215 & +0.143 \\
\hline \multirow[t]{2}{*}{ J. C. } & \multirow{2}{*}{$\left.\begin{array}{l}\text { T.p., 25 } \\
\text { T.p., 25 } \\
\text { E.b., 1.66 }\end{array}\right\}$} & 18 & 190 & +1.57 & 28.3 & & -0.105 & +15 & & & & \\
\hline & & 18 & & +1.74 & $\frac{31.3}{59.6}$ & 61 & +0.145 & +35 & -0.101 & -44 & +0.175 & +0.120 \\
\hline F.S. & $\left.\begin{array}{l}\text { T.p., } 25 \\
\text { E.b., } 1.66\end{array}\right\}$ & 36 & 233 & +2.43 & 87.5 & 29 & +0.247 & +80 & -0.116 & -36 & +0.313 & +0.184 \\
\hline \multirow[t]{2}{*}{ R. V. K. } & \multirow{2}{*}{$\left.\begin{array}{l}\text { E.b., } 1.66 \\
\text { E.b., 1.66 } \\
\text { T.p., 50 }\end{array}\right\}$} & 12 & 681 & +0.02 & & & & & +0.057 & & & \\
\hline & & 12 & & +1.76 & 21.4 & 0 & +0.367 & & +0.040 & +28 & +0.047 & +0.037 \\
\hline
\end{tabular}

* Total $\mathrm{N}$ storage and rebound loss not calculated where control base-line was changing rapidly. $\dagger$ Including first two metabolic periods (12 days) after steroid discontinued.

$\ddagger$ E.b., $3.32 \mathrm{mgm}$. daily given during final 6-day period. 


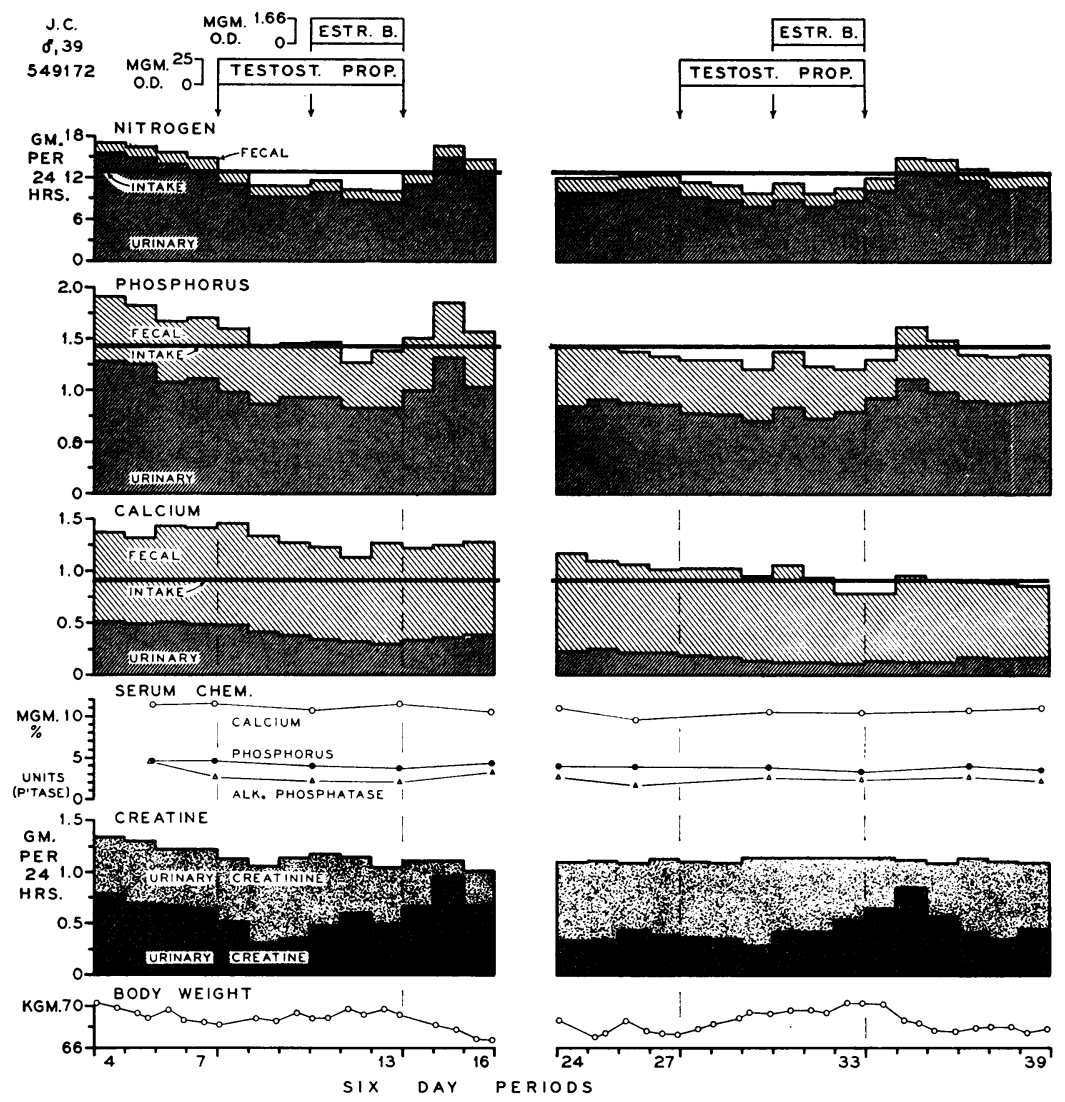

Fig. 6. Metabolic Data on Patient J.C., 39-Year-Old Male, during Second to Fourth Month and Sixth to Ninth Month after Onset of Paralytic Acute Anterior Poliomyelitis, Showing the Effects of Testosterone Propionate and Adped Estradiol Benzoate Given during the Convalescent and Late Convalescent-Chronic Phases

Explanation of construction of chart is in legend for Figure 1.

ful that the degree of reduction was significant. The reduction in negative calcium balance in R.W. was $0.274 \mathrm{gm}$. per day, and in D.A. calcium balance changed from -0.094 to +0.068 gm. per day, a shift of $0.162 \mathrm{gm}$. per day. Urinary citric acid rose less than $0.100 \mathrm{gm}$. per day while the hormones were being given, but when they were discontinued, citric acid rose briefly an additional 0.250 and $0.170 \mathrm{gm}$. per day, respectively. Both patients showed a fall in serum phosphorus, in R.W. amounting to 0.7 and in D.A. 0.9 mgm. per cent. Urinary 17-ketosteroids increased from a mean control value of $10.3 \mathrm{mgm}$. per day in R.W. to 18.8 and in D.A. from 9.9. mgm. per day to 16.8 .

J.C. (a male) on two occasions was given testosterone propionate $25 \mathrm{mgm}$. daily for 36 days, for the last 18 days of which he was also given 1.66 mgm. daily of estradiol benzoate (Figure 6). The first course was given during the third and fourth months and the second during the seventh and eighth months.

At the time the hormones were first given to J.C., nitrogen, calcium and phosphorus balances were all negative, creatinuria was at a high level and urinary creatinine was still gradually falling. During the first 18 days, on t.p. alone, nitrogen balance shifted from an average of $-2.48 \mathrm{gm}$. per day to an average of $+1.19 \mathrm{gm}$. per day; when e.b. was added, there was a further storage of nitrogen, the average balance being $+1.98 \mathrm{gm}$. per day. The total accumulated positive nitrogen balance was 57 grams; if calculated relative to the change from control base-line, storage would 
be considerably greater but would probably not be accurate because of the fact that the base-line was shifting. Rebound loss of nitrogen after cessation of the hormones was also difficult to calculate for the same reason; on the basis of absolute balance rebound loss was 61 per cent. In contrast to the other patients, J.C. showed a decrease in creatinuria on testosterone, from $0.655 \mathrm{gm}$. per day to 0.330 ; when estradiol was given, creatinuria increased again nearly to control levels. When the hormones were discontinued, creatinuria rebounded sharply to a level 0.300 gm. per day above control. Glycocyamine excretion began to increase on t.p., rose further on e.b. and t.p. combined and returned gradually to control levels 30 days after the two hormones were stopped; the control level was $0.122 \mathrm{gm}$. per day and the final peak on steroids $0.199 \mathrm{gm}$. per day. The effect of the hormones on urinary creatinine was apparently to bring about a temporary halt in the progressive fall to that point.

From examination of the decreases in urinary calcium excretion and negative calcium balance, it is difficult to determine whether estradiol added to the effect of testosterone; the total change in the 36-day interval was a fall of $0.195 \mathrm{gm}$. per day in urinary calcium and $0.215 \mathrm{gm}$. per day in the negative balance. Urinary citric acid excretion on t.p. increased in this patient from 0.636 gm. per day to 0.770 , and continued to rise an additional 0.100 gm. per day when e.b. was added; citric acid did not rise further when steroid administration was interrupted. Serum phosphorus progressively decreased, the total decline being $0.6 \mathrm{mgm}$. per cent. Urinary 17-ketosteroids rose from $6.6 \mathrm{mgm}$. per day to 11.8 during the 18 days on t.p., then remained at the same level while e.b. was also given.

When androgen and estrogen were administered again in the same fashion beginning during the seventh month, the resultant changes differed principally in derree and were, in general, slightly less marked. N.trogen balance was already slightly positive, became more positive on t.p. to the extent of $1.57 \mathrm{gm}$. per day on the average, then nitrogen balance remained virtually the same with e.b. added. Total nitrogen storage with respect to the control balance was $60 \mathrm{gm}$., and the rebound loss afterward, 61 per cent; these figures are similar to those stated for the first course of the hormones in this patient but were calculated on a different basis. The pattern of change in creatinuria was similar to that during the first course of these steroids, the chief differences being that the levels rose to a greater extent when estrogen was added and during the rebound following. From a control level of $0.384 \mathrm{gm}$. per day, creatinuria dropped to a $0.279 \mathrm{gm}$. per day average during the third metabolic balance period, then rose to $0.529 \mathrm{gm}$. per day in the sixth; during the second period following, the level was $0.847 \mathrm{gm}$. per day. The changes after the third period on steroid were probably not due specifically to estrogen since a similar pattern of fall and then rise occurred in D.A. who was given e.b. with t.p. from the start. As in the first course of the two steroids in J.C., urinary glycocyamine was increased, from 0.174 gm. per day to 0.234 . Urinary creatinine rose very slightly.

Decline in urinary calcium was much less than during the first course, $0.101 \mathrm{gm}$. per day, but the shift in calcium balance, -0.140 to $+0.035 \mathrm{gm}$. per day, was nearly the same. Changes in urinary citric acid differed from those of the first course; from a high control level of $0.871 \mathrm{gm}$. per day, on t.p. alone a definite fall occurred (to $0.669 \mathrm{gm}$. per day) which was only slightly reversed on e.b. (to $0.738 \mathrm{gm}$. per day). On cessation of the hormones citric acid rose over the first twelve days to an average of $0.828 \mathrm{gm}$. per day. A fall in serum phosphorus was again noted ( $0.8 \mathrm{mgm}$. per cent). Urine was not analyzed for 17-ketosteroids during this phase of the study.

b. Chronic phase. The effects of combined androgen and estrogen during the chronic phase were tested in two patients. The principal observation was made on F.S. (a male), who eight months after onset was given daily for 36 days $25 \mathrm{mgm}$. of testosterone propionate and $1.66 \mathrm{mgm}$. of estradiol benzoate. In a shorter study, R.V.K. (a female) 22 months after onset was given estradiol benzoate $1.66 \mathrm{mgm}$. daily for 24 days and during the last 12 days was also given $50 \mathrm{mgm}$. of testosterone propionate daily.

In the study on F.S., peak nitrogen retention was $+3.35 \mathrm{gm}$. per day during the third six-day metabolic balance period; balance shifted from +0.06 gm. per day during the preceding control balance periods to an average of +2.49 over the 36 days on the hormones. Total nitrogen storage was $89.6 \mathrm{gm}$.; the rebound loss over the following 
24 days was 29 per cent of the amount stored on the hormones. Urinary creatine changed little over the first 12 days on steroids, then rose to a peak during the fourth period which was $0.247 \mathrm{gm}$. per day above the control level; after steroid administration creatinuria increased an additional $0.070 \mathrm{gm}$. per day. Urinary glycocyamine increased steadily from a control level of $0.126 \mathrm{gm}$. per day to a peak of $0.240 \mathrm{gm}$. per day during the fifth period; glycocyamine returned to the control level 21 days after androgen-estrogen had been stopped. Urinary creatinine showed some irregular elevations which were of doubtful significance.

Urinary calcium in F.S. decreased from 0.319 gm. per day to $0.203 \mathrm{gm}$. per day by the second period after hormone administration. Fecal calcium appeared to be slightly but definitely reduced, and the calcium balance shifted from $-0.300 \mathrm{gm}$. per day to +0.013 . Urinary citric acid rose from $0.747 \mathrm{gm}$. per day to $0.900 \mathrm{gm}$. per day without an appreciable rise after the hormones were stopped. The usual decline in serum phosphorus was observed, amounting in this case to $0.7 \mathrm{mgm}$. per cent. Urinary 17 -ketosteroids rose slightly on the steroids from 14.4 to $17.4 \mathrm{mgm}$. per day, but fell to $7.9 \mathrm{mgm}$. per day three weeks following.

Administration of the hormones to R.V.K. was brief, but it did afford an opportunity to observe initially the effect of estrogen followed by the addition of androgen. Nitrogen balance was unchanged by e.b. but shifted from $+1.55 \mathrm{gm}$. per day to an average of $+3.29 \mathrm{gm}$. per day when testosterone was added ; administration of the hormones was so brief that total nitrogen storage and rebound loss were both extremely small. Creatinuria increased promptly and rose from $0.662 \mathrm{gm}$. per day to a peak of $1.029 \mathrm{gm}$. per day in the final combined period. After the hormone administration, creatinuria did not continue to rise but fell gradually over the next 24 days. The urine was not analyzed for glycocyamine. Creatinine was increased by $0.030 \mathrm{gm}$. per day, a 15 per cent change in this individual. As occured with one other patient (D.A.) on estrogen alone, urinary calcium increased from $0.141 \mathrm{gm}$. per day to 0.198 during the second balance period and remained elevated when t.p. was also given. The improvement in calcium balance was not significant. Urinary citric acid rose on e.b. ( $0.448 \mathrm{gm}$. per day to 0.671 ) and was promptly depressed back to the control level when t.p. was added. The fall in serum phosphorus amounted to $0.5 \mathrm{mgm}$. per cent. Urinary 17-ketosteroids from the second period on e.b. to the final combined period rose from 8.6 to $19.9 \mathrm{mgm}$. per day.

In all of the studies involving combined hormone administration, urinary phosphorus shifted with nitrogen and calcium. Measured phosphorus balances agreed closely with theoretical phosphorus balances calculated on the basis of the relationship of phosphorus to nitrogen and calcium in muscle and bone, respectively. Fecal phosphorus was reduced by $0.120 \mathrm{gm}$. per day in the study of F.S., but in all other studies of combined steroids changes in fecal phosphorus were minor, being less than $0.080 \mathrm{gm}$. per day.

\section{B. Changes in electrolyte excretion and balance}

Table III summarizes the data with respect to effect of the steroids on sodium and potassium balances and on urinary chloride excretion. Behavior of these elements was somewhat variable from one patient to another, but from a review of the data of the group a general pattern emerged. Sodium tended to be stored fairly promptly upon administration of the hormones, and in a few instances marked retention occurred during the first metabolic balance period, as indicated in the table. With regard to average sodium balance over the entire interval of steroid administration, however, a difference appeared in the effect on sodium between testosterone alone and when combined with estradiol, the combination causing sustained sodium retention while testosterone alone did not. This difference becomes evident if the testosterone data of D.A. and R.W. (I) ${ }^{3}$ are excluded. In these two studies t.p. was given relatively soon after onset of illness while hot packs were still being applied; the sodium excretion through the sweat, therefore, was undoubtedly considerable and variable so that sodium balance: in these two studies were inaccurate. In the re naining three studies of t.p. alone mean sodium balances on the hormone were virtually identical with the mean control sodium balances. Nevertheless, on cessation of t.p. all three patients had a sodium diuresis.

3 (I) following patient's initials indicates the first of two courses of similar hormone administration, (II) the second. 
TABLE III

Summary of data on potassium, sodium and water balance and urinary chloride excretion, effects of testosterone propionate and estradiol benzoate given singly and combined

\begin{tabular}{|c|c|c|c|c|c|c|c|c|c|c|c|c|c|c|c|}
\hline \multirow[b]{2}{*}{ Patient } & \multirow[b]{2}{*}{ Steroid } & \multirow[b]{2}{*}{$\underset{\text { day }}{\text { Initial }}$} & \multicolumn{3}{|c|}{ Potassium balance } & \multicolumn{4}{|c|}{ Sodium balance } & \multicolumn{3}{|c|}{ Urinary chloride } & \multicolumn{3}{|c|}{ Water balance } \\
\hline & & & $\begin{array}{l}\text { Con- } \\
\text { trol }\end{array}$ & $\begin{array}{l}\text { Av. on } \\
\text { steroid }\end{array}$ & $\begin{array}{l}\text { Post- } \\
\text { control† }\end{array}$ & $\begin{array}{l}\text { Con- } \\
\text { trol }\end{array}$ & $\underset{\text { period }}{\text { First }}$ & $\begin{array}{l}\text { Av. on } \\
\text { steroid }\end{array}$ & $\begin{array}{c}\text { Post- } \\
\text { control }\end{array}$ & $\begin{array}{c}\text { Con- } \\
\text { trol }\end{array}$ & $\begin{array}{l}\text { Av. on } \\
\text { steroid }\end{array}$ & $\begin{array}{l}\text { Post- } \\
\text { control }\end{array}$ & $\begin{array}{l}\text { Con- } \\
\text { trol }\end{array}$ & $\begin{array}{l}\text { Av. on } \\
\text { steroid }\end{array}$ & Post- \\
\hline & & & $\underset{d a y}{g m . /}$ & $\underset{\text { day }}{g m . /}$ & $\underset{d a y}{g m . /}$ & $\underset{d a y}{g m . /}$ & $\underset{d a y}{g m . /}$ & $\underset{\text { day }}{\operatorname{gm} . /}$ & $\underset{d a y}{g m . /}$ & $\underset{d a y}{g m . /}$ & $\underset{d a y}{g m . /}$ & $\underset{d a y}{g m . /}$ & $\begin{array}{c}m b . / \\
d a y\end{array}$ & ml./ & ml./ \\
\hline $\begin{array}{l}\text { D. A. } \\
\text { R. W. (I) } \\
\text { F. S. } \\
\text { C. R. } \\
\text { R.W. (II) } \\
\text { R. V. K. }\end{array}$ & $\begin{array}{l}\text { T.p. } \\
\text { T.p. } \\
\text { T.p. } \\
\text { T.p. } \\
\text { T.p. } \\
\text { T.p. }\end{array}$ & $\begin{array}{l}27^{*} \\
28 * \\
155 \\
158 \\
232 \\
615\end{array}$ & $\begin{array}{l}-0.037 \\
+0.089 \\
+0.359 \\
+0.246 \\
+0.518 \\
-0.219\end{array}$ & $\begin{array}{l}+0.212 \\
+0.080 \\
+0.586 \\
+0.409 \\
+0.418 \\
+0.340\end{array}$ & $\begin{array}{r}-0.360 \\
-0.115 \\
+0.156 \\
+0.197 \\
+0.344 \\
-0.112\end{array}$ & $\begin{array}{r}+0.029 \\
+0.091 \\
+0.180 \\
+0.314 \\
+0.620\end{array}$ & $\begin{array}{r}+0.158 \\
-0.030 \\
+0.048 \\
+0.510 \\
+0.697\end{array}$ & $\begin{array}{r}+0.449 \\
+0.508 \\
+0.045 \\
+0.322 \\
+0.738\end{array}$ & $\begin{array}{r}-0.022 \\
+0.212 \\
-0.157 \\
-0.136 \\
+0.192\end{array}$ & $\begin{array}{l}5.66 \\
5.41 \\
6.04 \\
5.63 \\
5.30\end{array}$ & $\begin{array}{l}5.58 \\
5.44 \\
5.95 \\
5.34 \\
5.06\end{array}$ & $\begin{array}{l}\mathbf{5 . 8 0} \\
5.67 \\
\mathbf{6 . 2 4} \\
\mathbf{5 . 8 4} \\
\mathbf{5 . 4 0}\end{array}$ & $\begin{array}{r}+903 \\
+593 \\
+151 \\
+330 \\
+547\end{array}$ & $\begin{array}{r}+771 \\
+380 \\
+259 \\
+481 \\
+695\end{array}$ & $\begin{array}{l}+298 \\
+272 \\
-101 \\
+171 \\
+913\end{array}$ \\
\hline R. W. (II) & & & +0.374 & +0.471 & +0.232 & +0.371 & +0.418 & +0.368 & -0.034 & 5.66 & 5.45 & 5.83 & +343 & +478 & +328 \\
\hline $\begin{array}{l}\text { D. A. } \\
\text { R. W. }\end{array}$ & $\begin{array}{l}\text { E.b. } \\
\text { E.b. }\end{array}$ & $\begin{array}{l}219 \\
190\end{array}$ & $\begin{array}{r}+0.264 \\
+0.092\end{array}$ & $\begin{array}{r}+0.087 \\
+0.060\end{array}$ & $\begin{array}{l}+0.074 \\
+0.040\end{array}$ & $\begin{array}{r}-0.185 \\
+0.458\end{array}$ & $\begin{array}{r}+0.761 \\
+0.446\end{array}$ & $\begin{array}{r}+0.387 \\
+0.502\end{array}$ & $\begin{array}{r}-0.229 \\
+0.491\end{array}$ & $\begin{array}{l}5.24 \\
5.30\end{array}$ & $\begin{array}{l}5.36 \\
4.84\end{array}$ & $\begin{array}{l}5.96 \\
5.27\end{array}$ & $\begin{array}{r}+491 \\
+605\end{array}$ & $\begin{array}{r}+365 \\
+569\end{array}$ & $\begin{array}{l}+196 \\
+388\end{array}$ \\
\hline $\begin{array}{l}\text { D. A. } \\
\text { R. W. } \\
\text { J. C. } \\
\text { J. C. } \\
\text { F. S. } \\
\text { R. V. K. }\end{array}$ & $\begin{array}{l}\text { Comb. } \\
\text { Comb. } \\
\text { Comb. } \\
\text { Comb. } \\
\text { Comb. } \\
\text { Comb. }\end{array}$ & $\begin{array}{r}99 \\
106 \\
70 \\
190 \\
233 \\
681\end{array}$ & $\begin{array}{l}+0.310 \\
+0.075 \\
+0.232 \\
+0.235 \\
+0.277 \\
+0.176\end{array}$ & $\begin{array}{l}+0.642 \\
+0.452 \\
+0.427 \\
+0.468 \\
+0.704 \\
+0.018\end{array}$ & $\begin{array}{l}+0.545 \\
-0.086 \\
-0.319 \\
-0.175 \\
+0.677 \\
-0.107\end{array}$ & $\begin{array}{l}+0.361 \\
+0.254 \\
+0.262\end{array}$ & $\begin{array}{r}+0.787 \\
+1.068\end{array}$ & $\begin{array}{r}+0.518 \\
+0.855\end{array}$ & $\begin{array}{r}-0.102 \\
+0.180 \\
+0.387\end{array}$ & $\begin{array}{l}5.62 \\
5.56\end{array}$ & $\begin{array}{l}5.24 \\
4.73\end{array}$ & $\begin{array}{l}6.11 \\
5.57\end{array}$ & $\begin{array}{l}+339 \\
+530 \\
+821 \\
+732 \\
+134 \\
+82\end{array}$ & $\begin{array}{r}+651 \\
+569 \\
+849 \\
+951 \\
+175 \\
+110\end{array}$ & $\begin{array}{r}+234 \\
+548 \\
+485 \\
+594 \\
+256 \\
+\quad 7\end{array}$ \\
\hline Mean & Comb. & & +0.140 & +0.452 & +0.089 & +0.292 & +0.709 & +0.604 & +0.155 & 5.67 & 5.18 & 5.83 & +440 & +551 & +354 \\
\hline
\end{tabular}

*Hot pack therapy.

tPost-control $=$ First 12 days after steroid discontinued.

On combined steroids, however, sodium balance was distinctly more positive (by 0.312 gm. per day on the average) than during the control periods; on stopping the hormones, balance was less positive than during control in two of the three studies. On e.b. alone one patient, D.A., showed definite sodium retention whereas the other patient, R.W., showed virtually no change in sodium balance.

Urinary chloride excretion was only slightly decreased (less than 4 per cent) during t.p. administration and slightly increased afterward. On combined hormone, however, the decrease in urinary chloride was more definite ( 9 per cent); again, there was a slight increase in chloride excretion following. On e.b. one patient showed a decrease similar in magnitude to that noted on combined steroid and one patient showed no change.

Crude water balances, based on fluid intake and output only, also showed a considerable degree of variation in certain patients. These data do not include calculations for the water of combustion of food or any estimates of changes in insensible water loss. Periodic determinations of the basal metabolic rate suggested that insensible water loss was probably increased during the early. weeks. During this period water was probably also being lost in considerable amounts through the skin due to hot packs. These routes of probable additional water loss might account for the apparently large positive water balances during the control phases prior to t.p. administration in D.A. and R.W. (I). Review of data in the other studies indicated a consistent tendency to retain small amounts of fluid on t.p. and on combined steroid as compared with the control water balances and a variable tendency to return to the control balance level after hormone was stopped. In five studies the data suggested a water diuresis upon discontinuation of the steroids, the water balance during the first two balance periods following being more than $300 \mathrm{ml}$. per day less positive than during steroid administration; in two patients the balance became more positive during the first two periods following steroid. In the two estrogen studies crude water balances were less positive on the steroid and again less positive thereafter.

Potassium balances indicated that this element tended to be stored or lost as nitrogen was stored or lost. On testosterone alone and on combined t.p. and e.b., potassium balances were more positive than during control periods, and when the hormones were stopped, potassium balances were less positive coincident with the rebound loss of nitrogen. Exception was noted in both the early and late t.p. studies of R.W. in which potassium balance did not become more positive when nitro- 
gen storage was substantially increased. In explanation, the rare possibility is suggested of coincidental marked error in the true potassium intake during these phases, the potassium content of foods being notoriously variable; occurrence of this discrepancy, however, twice in the same patient and not in the other patients seems to call for a different interpretation, one which we are unable to offer. The potassium balance of R.V.K. on combined steroid was influenced by the fact that t.p. was given and nitrogen storage increased during the last two metabolic periods only so that the predominant influence was that of e.b. In the two studies of e.b. alone, potassium balances became less positive on the estrogen as did also the nitrogen balances.

In view of the report of Bower, Morgan, and Chaney (21) of excessive potassium excretion during the early weeks in a group of poliomyelitis patients, nearly all of whom needed a respirator, a brief account may be made of potassium excretion during the first few weeks in the four patients studied during that phase. Urinary potassium was observed to rise to a peak level of 3.3 to $5.5 \mathrm{gm}$. per day at the 11th to 13th day. At the level of potassium intakes given, negative potassium balances were maximally of the order of $2.0 \mathrm{gm}$. daily; negative potassium balance lasted until three to four weeks after onset. In comparison with the extensive losses of nitrogen (1), these potassium losses were modest, as judged by theoretical potassium balances calculated from the ratio of potassium to nitrogen in muscle (20); actual potassium losses were considerably less than the theoretical. Even if actual potassium losses had been high, however, they would not have evidenced particular loss of nerve tissue since nerve is not as rich in potassium as muscle (22).

\section{Tests of Physiological Function}

\section{A. Basal metabolic rate}

Determinations of basal metabolic rate were made approximately every 10 days to 2 weeks so that an average of 20 determinations was made during each patient's several months' study.

Among the seven patients studied from within the first two months after onset, five showed a gradual decrease in basal metabolism (calories per M. ${ }^{2}$ per hr.) over the first two to six months. Based on comparison of groups of two or more determinations, this decrease ranged from 9 per cent in D.Q., occurring over the first two months only, to 32 per cent in R.W. from the first to the sixth month. Mean decrease for the five patients was 18 per cent; this was equivalent to a decline of approximately 17 percentage points in the clinical reporting system of per cent variation from Aub-DuBois standards. The other two patients, M.O'M. and J.C., showed fluctuations with no definite change.

Review of tests performed during administration of testosterone propionate revealed no clear change in the studies of D.A. and R.W. (I) where the steroid was given beginning at approximately one month after onset. In F.S., C.R., and R.W. (II) later on, basal metabolism was raised by testosterone 5.4, 3.7 and $4.0 \mathrm{cal}$. per M. ${ }^{2}$ per hr., respectively, or by an average of 13 per cent (approximately equivalent to an increase of 11 percentage points in relation to Aub-DuBois standards); when the hormone was discontinued, basal metabolism fell again to control levels. In R.V.K. only single tests were made before and during testosterone administration.

On combined testosterone and estrogen basal metabolism of D.A. and F.S. increased 2.7 and 4.9 cal. per M. ${ }^{2}$ per hr. or 8 and 15 per cent, respectively. In R.W. and R.V.K. too few tests were carried out. In both administrations of steroid to J.C., tests showed modest variations and no clear trend. On estrogen alone, tests in D.A. indicated a 13 per cent rise, whereas during the short period that estrogen was given to $R$.W. only one test was performed.

\section{B. Muscle strength}

The pattern of gradually increasing muscle strength from the second week for five or more months was described in the first paper of this series. Ergometer tests made at intervals of every one to two weeks showed increases during steroid administration in several patients, but in none did the tests suggest that these increases might be due to hormonal influence rather than just part of the natural course of improvement. 


\section{Leg girth}

During the first two to five months leg girth, measured every four to eight days, gradually decreased as involved leg muscles underwent varying degrees of atrophy (1). Hormonal administration during these first several months did not prevent nor alter the rate of this process.

When testosterone propionate was given five months or more after onset to four patients, a mean increase in calf circumference resulted amounting to $1.0 \mathrm{~cm}$. (approximately 3 per cent) and in thigh girth $1.2 \mathrm{~cm}$. (also approximately 3 per cent); a decrease of similar proportions occured over the first two weeks after the hormone was discontinued. Similar increases occurred with combined steroid, the average increase in calf circumference being $0.7 \mathrm{~cm}$. and in the thighs $1.0 \mathrm{~cm}$. Although electrolyte and water changes on testosterone and combined t.p. and e.b. were not marked, it is not possible to be at all certain that the increases in leg girth occurring on these steroids reflected increases in muscle mass.

On estrogen alone, D.A. showed no change in girth and R.W. an increase of only $0.4 \mathrm{~cm}$. in both calves and thighs, an insignificant amount.

\section{Skin temperature}

Measurements of skin temperature with the Hardy radiometer were made in two patients. In F.S. combined t.p. and e.b. brought about a rise in the temperature of the feet of $1.8^{\circ} \mathrm{C}$. and of the legs of $0.6^{\circ} \mathrm{C}$., accompanied by no significant change in total average skin temperature over the whole body. Testosterone alone in this patient and in C.R. resulted in no consistent changes in skin temperature in any area.

\section{E. Clinical effects}

Experience with use of gonadal hormones in these studies was reviewed for possible additions to our information regarding their clinical masculinizing or feminizing effects. Predominant findings were evidence of individual variation among patients and of neutralization of the side effects of one hormone by the high dosage of another hormone, which then exerted its own effects.
Among the male patients, predominant in this group, five were given testosterone propionate alone. One patient noted an increased frequency of erections and transiently developed acne with 400 to $450 \mathrm{mgm}$. and another acne after $600 \mathrm{mgm}$. The latter patient when given testosterone a second time noted some difficulty starting his urinary stream after approximately $450 \mathrm{mgm}$. but did not develop acne by the time the steroid was stopped after a total dose of $600 \mathrm{mgm}$. A third patient (F.S.) reported increased beard growth and an increase in sexual interest and erections when he had received 750 to $900 \mathrm{mgm}$. The other two patients were given 1050 and $1350 \mathrm{mgm}$. total without clinical effects.

The two male patients given estradiol alone both developed areolar tenderness and palpable tissue beneath the areolae; R.W. did so after $30 \mathrm{mgm}$. of estradiol benzoate and D.A. after 50 to $60 \mathrm{mgm}$. $(180,000$ and 300,000 to 360,000 rat units, respectively).

Combined androgen and estrogen were given to males on five occasions, in each instance at a ratio of $15 \mathrm{mgm}$. t.p. to $1 \mathrm{mgm}$. of e.b. R.W. noted areolar tenderness after $30 \mathrm{mgm}$. of estradiol ( 180,000 rat units), the same accumulated dosage at which this symptom was noted in this patient when e.b. was given alone. F.S. also noted areolar tenderness at this dosage, but the discomfort subsided as the hormones were continued; this patient had noted "masculinizing" symptoms at 750 to $900 \mathrm{mgm}$. of t.p. alone but on combined steroids noted no such effects by the time steroids were discontinued after $900 \mathrm{mgm}$. of t.p. had been given. J.C., given combined steroids twice, had areolar area tenderness after $15 \mathrm{mgm}$. of e.b. during one course and after approximately $25 \mathrm{mgm}$. during the other (90,000 and 150,000 rat units, respectively). D.A. had no feminizing discomfort after a total of $50 \mathrm{mgm}$. of e.b. with $600 \mathrm{mgm}$. of t.p. even though during the final metabolic balance period the androgen: estrogen ratio was only $7.5: 1$.

R.V.K., a female, developed huskiness of the voice and facial acne after $650 \mathrm{mgm}$. of testosterone propionate when given alone and after $600 \mathrm{mgm}$. when given with estradiol benzoate. The ratio of the combined steroids given this patient was $30: 1$ by weight, testosterone propionate to estradiol benzoate. 


\section{COM MENT}

The studies reported in this paper have indicated a number of metabolic and physiological effects of gonadal steroids in adult patients with paralytic poliomyelitis. The effects in general were similar to those previously reported in other conditions, but certain exceptions were noted.

\section{Effects on calcium metabolism}

Among the metabolic effects, probably the most important was the action of testosterone propionate and combined t.p. and estradiol benzoate in decreasing calcium excretion $(7,23)$. Onset of this action was slow, requiring as long as one to two weeks. Then, for the length of time the hormones were given in these studies (up to 42 days), the change was gradually progressive and tended to extend for up to 12 days after the hormones had been discontinued. Thereafter, urinary calcium excretion and balance generally returned sluggishly toward preceding levels. In a few instances, frequently during later months of the convalescent phase or during the chronic phase, calcium excretion remained more or less at the final level reached just following hormone administration. The pattern of action suggested that these hormones would produce an even greater total effect if given continuously or in repeated long courses rather than in the relatively brief investigative trials employed in these studies.

Reductive action on calcium excretion was shown by all three forms of hormone administration, androgen, estrogen and the combination of the two, but not consistently in the case of estrogen. The two estrogen studies were each of unusual interest, one because in it calcium storage occurred coincident with an increase in nitrogen excretion, the other because urinary calcium increased so that no net calcium storage resulted.

A number of previous studies have shown the efficacy of these hormones in conditions in which demineralization is already established, such as postmenopausal and senile osteoporosis (6, 12, 13), Cushing's syndrome (8-11) and acromegaly (14). The present studies suggest their possible usefulness either in the prevention of or in the reduction of the severity of mineral loss as it is occurring, in this and in other paralytic disorders or in other states in which immobilization plays a prominent part. Another potential benefit lies in the fact that the reduction in urinary calcium would lessen the likelihood of calculus formation; the accompanying reduction in urinary phosphorus would be additionally helpful. If these quantitative effects were combined with close attention to adequate urine volumes and if hormone combinations were given which would maintain satisfactory levels of urinary citric acid (see below), a decrease in incidence of urinary tract stone formation in immobilizing states seems reasonable to be expected.

\section{Nitrogen sparing action}

The nitrogen or protein sparing action of testosterone, alone or in combination with estrogen, was clearly demonstrated during the convalescent and chronic phases in these studies, as it has been consistently in many other observations $(4,10$, 23-26). A question of interest is whether the data gave any indication of the location of the deposited protein. Comparison of the concomitant changes in excretion of phosphorus and sulphur indicated that nitrogen was being stored with these elements in the proportion in which they are found in muscle tissue. The measured phosphorus balances were always within 5 per cent (as related to the intake level) of theoretical phosphorus balances calculated from the balances of nitrogen and calcium, anticipating that phosphorus would be excreted or stored with these elements in the proportion found in muscle and bone (20). Calculation of the ratios of urinary nitrogen to urinary sulphur, balance period by balance period, revealed them to lie generally within the usual or normal range of $14: 1$ to $16: 1$ (1), but occasionally values as high as $17.5: 1$ were obtained. A frequent tendency toward higher ratios appeared during administration of testosterone and immediately following, suggesting the possibility at those times of more tenacious storage of sulphur-rich compounds.

The nitrogen-phosphorus-sulphur relationships indicated that protein was likely being stored in tissues having the composition of muscle, but no way was evident of determining whether there might be any predilection of the stored protein for denervated muscle, intact muscle or other tissues of similar composition. Reassurance that the pro- 
tein was being stored mainly in muscle rather than in other tissues is afforded by the finding of Kochakian, Robertson, and Bartlett (27) that in rats given testosterone propionate protein was deposited in preferential order in carcass, then seminal vesicles and prostate, liver and kidney. An experimental study bearing directly on the question of possible protection of denervated muscle by gonadal steroids is that of Gordan, Feinstein, and Ralston (28); in this study the right sciatic nerve was resected in two of three groups of rats. Testosterone propionate did not affect the atrophy, length-tension relationships or histology of the denervated anterior tibial muscles. The contralateral normal muscles in these animals, however, were approximately 5 per cent heavier than the muscles of untreated control rats. From these experiments considered in conjunction with our own studies, it seems reasonable to suppose that protein stored under the influence of testosterone was being deposited principally in intact, uninvolved muscle fibers. Leg girth measurements in our studies did not provide information which would aid in establishing this point, such as greater increase in girth of uninvolved versus involved limbs. In all patients involvement was nearly equal bilaterally. In the one patient, R.W., who had less leg muscle impairment than the others, increase in girth on testosterone was no greater, although his period on t.p. was somewhat shorter than that of the other patients ( 24 versus 42 days).

It is important to note that a definite proteinsparing action of testosterone was not obtained during the period of excessive nitrogen excretion in the first two months. In another situation embodying nitrogen loss, the period after injury, correction of negative nitrogen balance has been attempted by dietary means and found difficult (29).

The action of estrogen in these studies in increasing nitrogen excretion is contrary to the findings of Albright and Reifenstein in post-menopausal and senile osteoporosis $(6,12,13)$ and of Knowlton, Kenyon, Sandiford, Lotwin, and Fricker (30) in normal women; these investigations had indicated a modest but definite nitrogensparing action. Reifenstein (25) summarized the results of studies using $1.66 \mathrm{mgm}$. of estradiol benzoate and found an average nitrogen retention of $16 \mathrm{mgm}$. per $\mathrm{Kg}$. per day during days 5 to 15 , equivalent to more than $1 \mathrm{gm}$. per day in an average sized individual at a daily intake of $13.5 \mathrm{gm}$. of nitrogen. In Cushing's syndrome, however, estrogen has been given to two cases (8) with similar findings to those of the present study in that an adverse effect on nitrogen balance developed accompanied by a slightly beneficial effect on calcium balance. Experimentally, a related effect is suggested by the production by stilbestrol of an increase in urinary glucose and nitrogen in normal and partially depancreatized rats (31).

The question of any influence of gonadal steroids upon fecal nitrogen excretion was reviewed by Kochakian (4) who reported that no effect was noted in seven studies of a considerable variety of patients. The present studies confirm these reports.

\section{Creatine synthesis and storage}

Testosterone propionate and methyl testosterone are generally regarded as having dissimilar effects on creatine metabolism. The 17-methyl compound causes an excess creatinuria and is believed to stimulate creatine synthesis and enhance creatine storage; the propionate is thought to favor only the storage of creatine (32). Kochakian (4) has stated that the effects of the two compounds may be alike and that there is only an apparent dissimilarity due to the likelihood that the 17-methyl group hastens these effects. Keutmann, Bassett, and Kochakian (33) measured the creatinuria after cessation of testosterone propionate in a patient with Cushing's syndrome, found it greater than the amount retained during administration of the hormone and concluded that the propionate increases both synthesis and storage of creatine. Our studies support this latter view. In one patient with more unaffected total muscle mass than the others, a decrease in creatinuria occurred indicative of increased storage. In the other patients, however, creatinuria gradually increased, suggestive of increased synthesis. In two instances (D.A. and R.W. [II]) the increase in creatinuria on testosterone was followed by a sharp additional increase reminiscent of the rebound rise seen in patients with normal muscle metabolism immediately following testosterone propionate; in these two instances evidence is visible of both increased synthesis and storage. 
These various patterns may all be reconciled by the hypothesis that both synthesis and storage are aided by this steroid.

The indication that synthesis is increased by testosterone propionate is supported by the glycocyamine data. Urinary excretion of this substance was measured in three testosterone studies. In the second study of R.W. and in the two studies of J.C., the latter having been given testosterone alone for 18 days prior to combined steroid, substantial increases in urinary glycocyamine excretion occurred. The increased excretion of this known creatine precursor suggests that production of the glycine-amidine part of the creatine molecule had been increased in liver and kidney.

A different situation was apparently present with regard to the influence of testosterone on creatine synthesis during the first two months after onset, as indicated by absence of change of glycocyamine excretion in the two patients given testosterone during this early phase. This lack of response in glycocyamine occurred at a time when urinary creatine levels were still high so that the possibility comes to mind that an increase in creatine production by hormone may have been suppressed by the already copious amounts available and circulating. This situation may be similar to that noted in a study in progressive muscular dystrophy $(34,35)$ in which testosterone propionate failed to produce an increase in urinary glycocyamine; an increase in creatine storage occurred in these dystrophy patients since a rise in creatinuria resulted after the hormone was stopped.

In the two studies in which estradiol was given, a distinct increase was noted in creatinuria and in urinary glycocyamine indicative of a stimulation of creatine synthesis by this hormone. Since creatinuria began to fall within a few days after estradiol was stopped and since, in any event, there was no rebound rise in creatinuria similar to that following testosterone, it seems probable that little or no increase in creatine storage occurred under the influence of this estrogen. Increased urinary creatine excretion by an estrogen has been barely noted in previous studies. Knowlton, Kenyon, Sandiford, Lotwin, and Fricker (30) described an increase in creatinuria from 0.200 to $0.400 \mathrm{gm}$. per day on $5 \mathrm{mgm}$. of estradiol in a girl with adrenogenital syndrome but not on administration to a normal woman. From the charted data of Case 10 in the study of Williams, Whittenberger, Bissell, and Weinglass (36) of Addison's disease, there appeared to be a slight increase in creatinuria on $5 \mathrm{mgm}$. of stilbestrol given for six days. Because of the plan of the study of Deakins, Friedgood, and Ferrebee (37) of a patient with Cushing's syndrome, it was difficult to determine whether creatinuria had been influenced by stilbestrol. We have been unable to find measurements of urinary glycocyamine in previous studies of the effects of estrogens.

Increases in urinary creatinine in a number of instances during the course of testosterone and combined steroid administration reflected the suggested enhancement of creatine synthesis and storage. These increases in creatinine, however, occurred in only approximately one-half of the studies and quantitatively were usually small.

\section{Changes in electrolyte excretion}

Because of similarities in structure between the gonadal steroids and adreno-cortical hormones, Thorn and Harrop (38) suspected that androgenic and estrogenic preparations might have salt and water retaining properties. In normal male dogs they demonstrated $(38,39)$ reduction in urinary volume, sodium and chloride and a slight increase in urinary potassium by single injections of these steroids, estradiol and progesterone having the greatest sodium retaining effect and testosterone the least. In addition, estrone, alpha-estradiol and testosterone caused a decrease in urinary phosphate and nitrogen; testosterone propionate (25 mgm. daily) given to a normal male subject brought about a reduction in urinary potassium as well as in sodium, chloride, phosphorus and nitrogen (39). Thorn, Nelson, and Thorn (40) extended observations in dogs of the effect of ovarian hormones and testosterone on salt and water retention and investigated human pre-menstrual weight gain, finding it associated with sodium, chloride and water retention and the increased urinary excretion of "estrogenic substance."

The present study confirms Thorn's opinion that testosterone is a relatively weak sodium retainer in that sodium balances over several metabolic balance periods on this steroid averaged the same as the control balances; two of three patients, 
however, showed distinct sodium retention during the first six days on testosterone and all showed sodium diuresis when it was withdrawn. Variation from patient to patient was emphasized by the marked sodium retention by one patient on estradiol benzoate and virtually none by the other patient. When the two steroids were given together, definite sodium retention consistently occurred, but here again individual variation was evident.

Urinary chloride excretion data were less variable than the sodium data, urinary chloride being diminished slightly in all three forms of hormone administration; no change occurred in one of the estradiol studies. Chloride diuresis after the hormones were discontinued occurred in five studies and did not in three.

The water balance data were consistent with respect to the effects of testosterone and combined steroid in that all studies with these two forms of hormone showed more positive water balances on steroid, by an average of a little more than 100 $\mathrm{ml}$. daily. This is more than twice the amount of fluid storage associated with new protoplasm which would be anticipated (20) from the average nitrogen storage when testosterone or combined steroid were given (2.47 gm. $\mathrm{N}$ per day). Subsequent water diuresis occurred less consistently, although in five studies the water balance over the first twelve days after steroid was discontinued averaged more than $300 \mathrm{ml}$. per day less positive than during steroid administration.

Water balance data on the two patients on estradiol, however, recall the conflicting results obtained in various studies since those of Thorn. Knowlton and her co-workers (30) noted a decrease in urine volume on estradiol in one experiment and later noted no change in a second experiment on the same patient. Shapiro (41), who gave $7.5 \mathrm{mgm}$. of estradiol benzoate daily for five days to patients with secondary amenorrhea and to patients with diabetes insipidus, consistently obtained a decrease in urine volume followed by an increase when estradiol was stopped. On the other hand, Sharpey-Schafer and Schrire (42), who gave estradiol benzoate in approximately the same dosage as Shapiro for 7 to 10 days to 14 women, before and after the menopause, reported no decrease in urine volume. In our two males the latter result was largely obtained with perhaps a slight loss of water on estradiol and a further loss following. No evidence was found in our data for a transient storage of water during the first few days on estrogen as reported recently by Preedy and Aitken (43) using a larger dose.

Potassium balances became more positive on testosterone and combined steroid in association with nitrogen storage. On estradiol, potassium balances became less positive as did also the nitrogen balances. Although it is possible that these gonadal steroids may have a desoxycorticosteronelike action on the kidney, as has been suggested (39), apparently this action is obscured if the hormones provide sufficient stimulus to tissue growth and nitrogen storage, requiring the accompanying deposition of potassium. This would explain in the present studies the differences in effect on potassium balances between testosterone and estradiol.

\section{Effects on urinary 17-ketosteroid excretion}

The increases in urinary 17 -ketosteroids on testosterone propionate in the present studies were in accord with previous experience (44). Reports of the effects of estrogens on 17-ketosteroids are apparently meagre. Hamblen, Pattee, and Cuyler (45) in 22 women with various types of ovarian insufficiency noted elevated "androgenic titers" and with estradiol lowered them to normal, the reductions ranging from 14 to 30 per cent. Salter, Hum, and Oesterling (46) in a female pseudohermaphrodite brought about a marked decrease (approximately 80 per cent) with $10 \mathrm{mgm}$. daily of stilbestrol. In our two male patients given estradiol benzoate the 17 -ketosteroids were lowered by 22 per cent and 34 per cent, in the general range of reduction noted by Hamblen, Pattee, and Cuyler. Presumably the decreased excretion results from partial suppression of anterior pituitary production of gonadotrophin or ACTH or both.

\section{Effects on urinary citric acid excretion}

Opposing effects of androgen and estrogen were seen consistently on urinary citric acid excretion, androgen decreasing and estrogen increasing. When the steroids were combined, the usual result was a neutralization so that citric acid varied little from the control level. When the combined. 
steroids were stopped, frequently a rise in urinary citric acid appeared, suggesting a prolongation of the estrogen effect on this constituent.

The action of estrogen to increase urinary citric acid is an important one for the problem of urinary tract stone formation, particularly where large amounts of calcium are being excreted. Abundant amounts of citric acid in the urine are useful for assistance in keeping calcium in solution $(19,47)$. Thus, although testosterone alone supplies many of the principal, desired metabolic effects which would assist in the management of the clinical problem of paralysis, the addition of estrogen serves a particularly useful purpose in counteracting the lowering effect of androgen on urinary citric acid.

Testosterone was also shown to cause a small but consistent increase of 0.2 unit in urinary $\mathrm{pH}$. This change, although extremely slight, is in the direction tending to be unfavorable for calcium solubility. This effect was not consistently seen on combined steroid and not at all on estradiol benzoate.

\section{Basal metabolic rate}

The somewhat limited number of tests of basal metabolic rate suggested a gradual decline in basal metabolism over the course of the first two to six months after onset; this was noted in five of the seven patients studied from within the first two months of onset. (The possibility that respiratory muscle involvement might impair the accuracy of the determinations was a factor in only one patient ; the decline in his rate was similar to that of the other patients.) This downward trend in basal metabolic rate extended for approximately the duration of negative nitrogen balance and of decline in urinary creatinine; the possibility is suggested that the fall in basal metabolism occurred because of the considerable decrease in active protoplasmic mass in these patients.

More uniformly, administration of the gonadal steroids brought about an increase of 8 to 15 per cent in basal metabolism. This rise was of the same general range as the increase noted in most of the series reported to date $(4,24,48)$. The few series in which an increase was not noted upon administration of this steroid were apparently those in which it was given for less than 10 days or in doses of less than $25 \mathrm{mgm}$. daily.

\section{Clinical or side effects}

In addition to their metabolic effects, gonadal hormones have various clinical effects (49-51) related mainly to their responsibility in natural production for the maleness or femaleness of the individual. Although certain undesirable side-effects may occur when a hormone is given to a patient of the same gender, by far the more disturbing effects are related to the production of symptoms or signs generally attributed to the opposite sex. These sex-related effects have been responsible for reluctance on the part of many physicians to use these hormones widely. It has not been clear whether some of these side-effects might be overcome by use of combinations of male and female hormones or only by restriction of daily or total dosage to certain limits, the latter course possibly leading at least in part to loss of useful action.

Review of the clinical or side effects from the administration of gonadal steroids in this series revealed mainly considerable variation from patient to patient in the accumulated dosage level at which these effects became evident. On testosterone, for example, two male patients developed acne after 400 and $600 \mathrm{mgm}$., respectively, and two others no noticeable effects after 1050 and 1350 mgm. The small experience in this predominantly male group of patients tended to support the idea that a 20:1 weight ratio of testosterone propionate to estradiol benzoate is neutralizing with respect to clinical effects (52); a 15:1 ratio was usually slightly feminizing and $30: 1$ in the one instance given was masculinizing. This tentative conclusion should not be projected to effects to be anticipated either on longer administration of steroids or in predominantly female groups of patients. In the few instances in which it was possible to observe the situation, a dosage of a hormone, which produced side-effects when given alone, did not if given again with the hormone of the opposite sex, the latter being in preponderant dosage; in these second circumstances the now preponderant hormone exerted its own clinical effects.

\section{Comparison of effects of testosterone propionate alone and combined with estradiol benzoate}

An evaluation of whether estrogen in combination with androgen exerted greater effects than androgen alone was possible in three patients and 
to a limited extent in a fourth. Most observations indicated no clear advantage of combined steroid administration. Nitrogen storage was slightly greater on androgen alone in two patients and slightly more on combined steroids in one, but the significant difference with respect to nitrogen was that the rebound loss after discontinuation of hormone was considerably greater with combined steroid administration; after testosterone alone the rebound loss of nitrogen averaged only 8 per cent of the total stored on the steroid. Creatinuria was increased more by combined steroid in two patients and by testosterone alone in one; in the latter patient, glycocyamine excretion was measured under both forms of hormone administration and was found to be more increased by combined steroid. A lack of consistent pattern was also present with respect to the minor changes in urinary creatinine. Decreases in serum phosphorus and increases in urinary 17 -ketosteroids were virtually the same on either form of steroid.

In calcium and citric acid metabolism, however, advantages were indicated for giving estrogen and androgen together over androgen alone, although not in every case. Allowing for the fact that more marked changes were possible during the early months when excretion of calcium was at high level, the urinary calcium of two patients, D.A. and R.W., was more greatly lowered (and over a shorter period) by combined steroid than by testosterone alone, particularly percentagewise. In F.S., the percentage reduction was equal by the two forms although the decrease was quantitatively greater by testosterone, given earlier than the combined. In contrast to these effects, estradiol benzoate given alone caused an increase in urinary calcium in two of the three instances in which it was given. Negative calcium balance was considerably more greatly reduced by combined steroid than by t.p. in one patient, R.W. In D.A., the reduction of negative balance was approximately the same by the two forms, although it may be pointed out that testosterone alone was given for six days longer. The data of F.S. were preliminarily reported (53) to show a greater reduction by combined steroid to the extent of $85 \mathrm{mgm}$. per day; this figure is correct if one compares only the control balance with the last metabolic balance period on steroid. If one takes into account, however, the frequent continuation of effect after hor- mone is stopped, which in this patient led to a continuing reduction in calcium excretion over the next 12 days after testosterone was discontinued, then the change in calcium balance in this patient was approximately equal by both forms of steroids. The studies of R.V.K. are difficult to compare with respect to calcium metabolism because of their short duration and the preponderant total dosage of estradiol when combined steroid was given. In the studies of J.C. in which combined steroid was given preceded by 18 days on testosterone alone, no obvious effect was noted in nitrogen, phosphorus or calcium metabolism from the addition of the estrogen to testosterone.

This lack of uniform advantage of combined steroid over testosterone alone was pointed out in a recent review (53) of twelve cases in the literature in which the effects of the two forms of steroid administration on calcium balance could be compared. In four of the twelve cases no difference was detectable, while in eight an additive effect of estrogen was present, usually equal to approximately $100 \mathrm{mgm}$. of calcium per day. Despite this lack of uniformity, the number of instances of added benefit to calcium storage (or reduced loss) from combined steroids was in the majority. Consideration should also be given to the added advantage of combined steroids for providing levels of urinary citric acid more protective of calcium solubility than those produced by testosterone alone. For these reasons, in clinical situations in which urinary tract stone formation and large losses of calcium from the skeleton are serious threats, it seems preferable to advise combined administration of testosterone and estrogen.

\section{Application to treatment of disease}

These studies were originally inititated for the purpose of increasing knowledge of the natural processes of paralytic acute anterior poliomyelitis and of possibly indicating improved methods of management. Fortunately, the evident promise of poliomyelitis vaccine makes these findings less widely applicable to infantile paralysis. Nevertheless, a number of features which have been described in these papers are presumably common, in varying degree, to other conditions, such as paraplegia or extensive injury, and the hormonal effects observed should have useful application to these disorders. 


\section{SUMMARY}

The fourth paper in this series on metabolic studies in paralytic acute anterior poliomyelitis described studies of the effects of administration of gonadal steroid hormones in seven patients. During various phases of the disease, testosterone propionate was given on eight occasions for periods ranging from 12 to 42 days. Estradiol benzoate was twice given alone during the convalescent phase, for 18 and 30 days each. The two steroids were given together in six studies for periods of 12 to 36 days. The principal findings were as follows :

1. During the convalescent and chronic phases testosterone propionate alone and combined with estradiol benzoate in nine studies brought about a mean daily storage of nitrogen of $2.5 \mathrm{gm}$. From various considerations, it was thought probable that the stored protein was being deposited principally in uninvolved muscle fibers. Rebound loss of nitrogen following testosterone alone averaged 8 per cent of the total stored during steroid administration; rebound loss of nitrogen following combined steroids averaged 38 per cent. In two studies during the early convalescent phase when nitrogen excretion was high, testosterone did not bring about a clear nitrogen-sparing effect. Estradiol benzoate alone brought about an increase in urinary nitrogen resulting in an average daily nitrogen loss of $0.78 \mathrm{gm}$.

2. The pattern of creatinuria and increase in urinary glycocyamine on testosterone propionate, given during the convalescent and chronic phases, indicated that this steroid caused an increase in the synthesis of creatine as well as in its storage. During the early convalescent phase when creatinuria was particularly high, no increase in urinary glycocyamine occurred on testosterone propionate. The pattern of creatinuria and increase in urinary glycocyamine on estradiol benzoate suggested that this steroid caused an increase in synthesis of creatine but probably not in its storage.

3 . Urinary calcium excretion and negative calcium balance were reduced by 0.100 to more than $0.300 \mathrm{gm}$. per day by both testosterone alone and combined testosterone and estradiol. Among the three patients in whom effects of the two forms of steroid on calcium balance could be compared, combined steroids were demonstrated to have a clear advantage over testosterone alone in one. Estradiol benzoate alone, in two of the three instances in which it was given, caused a slight but definite rise in urinary calcium.

4. Urinary citric acid excretion was reduced by testosterone propionate in all but one patient and increased by estradiol benzoate. When the two steroids were given together, urinary citric acid varied little from control levels. The significance of these effects for urinary calcium solubility was pointed out.

5. Serum phosphorus was reduced slightly by testosterone and by combined steroids and unchanged by estradiol; no other significant serum chemistry changes were noted.

6. Sodium tended to be stored transiently under the influence of testosterone, but mean sodium balances over the entire course of testosterone administration were virtually identical with control sodium balances; sodium diuresis occurred, however, when testosterone was discontinued. On combined steroids definite and continuing sodium retention occurred. On estradiol, sodium retention occurred in one patient and not in another. Urinary chloride excretion diminished slightly during all three forms of hormone administration.

7. Water retention averaging slightly more than $100 \mathrm{ml}$. per day occurred on testosterone alone and on combined steroids; in five studies, water balances during the first 12 days following discontinuation of these steroids were more than $300 \mathrm{ml}$. per day less positive than during steroid administration. Water retention did not occur on estradiol benzoate alone in the two males to whom this steroid was given.

8. Potassium was retained on testosterone alone and on combined steroids. Potassium balances became less positive on estradiol benzoate.

9. Observations with respect to physiological functions were as follows: Increase in basal metabolic rate on all three forms of steroid administration was 8 to 15 per cent. Gradual improvement in muscle strength during the convalescent phase did not appear to be influenced by hormone administration. Small increases in calf and thigh girth occurred on testosterone and combined steroids. Combined steroids brought about a rise in skin temperature of the feet and legs in the one patient in which this study was made; testosterone 
alone caused no rise in skin temperature in the two patients so observed.

10. Considerable variation was noted in the level of accumulated dosage at which clinical masculinizing or feminizing effects appeared.

\section{REFERENCES}

1. Whedon, G. D., and Shorr, E., Metabolic studies in paralytic acute anterior poliomyelitis. I. Alterations in nitrogen and creatine metabolism. J. Clin. Invest., 1957, 36, 942.

2. Whedon, G. D., and Shorr, E., Metabolic studies in paralytic acute anterior poliomyelitis. II. Alterations in calcium and phosphorus metabolism. J. Clin. Invest., 1957, 36, 966.

3. Whedon, G. D., and Shorr, E., Metabolic studies in paralytic acute anterior poliomyelitis. III. Metabolic and circulatory effects of the slowly oscillating bed. J. Clin. Invest., 1957, 36, 982.

4. Kochakian, C. D., The protein anabolic effects of steroid hormones. Vitamins \& Hormones, 1946, 4, 255.

5. Papanicolaou, G. N., and Falk, E. A., General muscular hypertrophy induced by androgenic hormone. Science, 1938, 87, 238.

6. Reifenstein, E. C., Jr., and Albright, F., The metabolic effects of steroid hormones in osteoporosis. J. Clin. Invest., 1947, 26, 24.

7. Albright, F., and Reifenstein, E. C., Jr., The Parathyroid Glands and Metabolic Bone Disease. Baltimore, The Williams \& Wilkins Co., 1948, p. 159.

8. Albright, F., Parson, W., and Bloomberg, E., Cushing's syndrome interpreted as hyperadrenocorticism leading to hypergluconeogenesis: results of treatment with testosterone propionate. J. Clin. Endocrinol., 1941, 1, 375.

9. Albright, F., and Reifenstein, E. C., Jr., The Parathyroid Glands and Metabolic Bone Disease. Baltimore, The Williams \& Wilkins Co., 1948, p. 165.

10. Kenyon, A. T., Knowlton, K., and Sandiford, I., The anabolic effects of the androgens and somatic growth in man. Ann. Int. Med., 1944, 20, 632.

11. Keutmann, E. H., Friedman, H. A., Bassett, S. H., Kochakian, C. D., and Russ, E. M., Metabolic studies in Cushing's syndrome. Am. J. Med., 1948, $5,518$.

12. Albright, F., Bloomberg, E., and Smith, P. H., Postmenopausal osteoporosis. Tr. A. Am. Physicians, 1940, 55, 298.

13. Albright, F., and Reifenstein, E. C., Jr., The Parathyroid Glands and Metabolic Bone Disease. Baltimore, The Williams \& Wilkins Co., 1948, p. 158.

14. Albright, F., and Reifenstein, E. C., Jr., The Parathyroid Glands and Metabolic Bone Disease. Baltimore, The Williams \& Wilkins Co., 1948, p. 190.
15. Sherman, M. S., Estrogens and bone formation in the human female. J. Bone \& Joint Surg., 1948, 30-A. 915.

16. Gardner, W. U., and Pfeiffer, C. A., Influence of estrogens and androgens on the skeletal system. Physiol. Rev., 1943, 23, 139.

17. Armstrong, W. D., Knowlton, M., and Gouze, M., Influence of estradiol and testosterone propionates on skeletal atrophy from disuse and on normal bones of mature rats. Endocrinol., 1945, 36, 313.

18. Roth, P., Modifications of apparatus and improved technic adaptable to the Benedict type of respiration apparatus. Boston M. \& S. J., 1922, 186, 457.

19. Shorr, E., Almy, T. P., Sloan, M. H., Taussky, H., and Toscani, V., The relation between the urinary excretion of citric acid and calcium; its implications for urinary calcium stone formation. Science, 1942, 96, 587.

20. Reifenstein, E. C., Jr., Albright, F., and Wells, S. L., The accumulation, interpretation and presentation of data pertaining to metabolic balances, notably those of calcium, phosphorus and nitrogen. $\mathrm{J}$. Clin. Endocrinol., 1945, 5, 367.

21. Bower, A. G., Morgan, F. M., and Chaney, A. L., Nitrogen and potassium metabolism: the reaction pattern in poliomyelitis. Am. J. M. Sc., 1952, 223, 532.

22. Shohl, A. T., Mineral Metabolism. New York, Reinhold Publishing Co., 1939, p. 19, Table 4, p. 34, and p. 38, Figure 4 .

23. Albright, F., The effect of hormones on osteogenesis in man. Rec. Prog. Hormone Research, 1947, 1, 293.

24. Kenyon, A. T., Sandiford, I., Bryan, A. H., Knowlton, K., and Koch, F. C., The effect of testosterone propionate on nitrogen, electrolyte, water and energy metabolism in eunuchoidism. Endocrinology, 1938, 23, 135.

25. Reifenstein, E. C., Jr., The Protein Anabolic Activity of Steroid Compounds in Man. A tabulation of substances tested to December 1942. Supplement to Minutes of First Meeting of Conference on Bone and Wound Healing, sponsored by Josiah Macy, Jr. Foundation, Sept. 11-12, 1942.

26. Dorfman, R. I., Physiology of androgens in The Hormones, Vol. II, Pincus, G. and Thimann, K. V., Eds., New York, Academic Press, Inc., 1950, p. 33.

27. Kochakian, C. D., Robertson, E., and Bartlett, M. N., Sites and nature of protein anabolism stimulated by testosterone propionate in the rat. Am. J. Physiol., 1950, 163, 332.

28. Gordan, G. S., Feinstein, B., and Ralston, H. J., Effect of testosterone upon atrophy of denervated skeletal muscle. Exper. Med. \& Surg., 1949, 7, 327.

29. Peters, J. P., Nitrogen metabolism in acute and chronic disease. Ann. New York Acad. Sc., 1946, 47, 327. 
30. Knowlton, K., Kenyon, A. T., Sandiford, I., Lotwin, G., and Fricker, R., Comparative study of metabolic effects of estradiol benzoate and testosterone propionate in man. J. Clin. Endocrinol., 1942, 2, 671.

31. Ingle, D. J., Diabetogenic effect of stilbestrol in force-fed normal and partially depancreatized rats. Endocrinology, 1941, 29, 838.

32. Wilkins, L., and Fleischmann, W., Studies on the creatinuria due to methylated steroids. J. Clin. Invest., 1945, 24, 21.

33. Keutmann, E. H., Bassett, S. H., and Kochakian, C. D., The influence of testosterone propionate, methyl testosterone and methyl androstanediol on creatine metabolism. Endocrinology, 1944, 35, 222.

34. Hoagland, C. L., Shank, R. E., and Gilder, H., Effect of testosterone propionate and methyl testosterone on creatinuria in progressive muscular dystrophy. Proc. Soc. Exper. Biol. \& Med., 1944, 55, 49.

35. Hoagland, C. L., Gilder, H., and Shank, R. E., The synthesis, storage, and excretion of creatine, creatinine, and glycocyamine in progressive muscular dystrophy and the effects of certain hormones on these processes. J. Exper. Med., 1945, 81, 423.

36. Williams, R. H., Whittenberger, J. L., Bissell, G. W., and Weinglass, A. R., Treatment of adrenal insufficiency. J. Clin. Endocrinol., 1945, 5, 163.

37. Deakins, M. L., Friedgood, H. B., and Ferrebee, J. W., Some effects of testosterone, testosterone propionate, methyl testosterone, stilbestrol and X-ray therapy in a patient with Cushing's syndrome. J. Clin. Endocrinol., 1944, 4, 376.

38. Thorn, G. W., and Harrop, G. A., The "sodium retaining effect" of the sex hormones. Science, 1937, 86, 40.

39. Thorn, G. W., and Engel, L. L., The effect of sex hormones on the renal excretion of electrolytes. J. Exper. Med., 1938, 68, 299.

40. Thorn, G. W., Nelson, K. R., and Thorn, D. W., A study of the mechanism of edema associated with menstruation. Endocrinology, 1938, 22, 155.
41. Shapiro, B. G., Control of urinary secretion by the anterior pituitary. Lancet, 1938, 2, 1457.

42. Sharpey-Schafer, E. P., and Schrire, I., Effect of estrogens on the urinary volume. Lancet, 1939, 2, 973.

43. Preedy, J. R. K., and Aitken, E. H., The effect of estrogen on water and electrolyte metabolism. I. The normal. J. Clin. Invest., 1956, 35, 423.

44. Mason, H. L., and Engstrom, W. W., The 17-ketosteroids : their origin, determination and significance. Physiol. Rev., 1950, 30, 321.

45. Hamblen, E. C., Pattee, C. J., and Cuyler, W. K., Alteration of urinary excretion of androgens by estrogenic therapy. Endocrinology, 1940, 27, 734.

46. Salter, W. T., Humm, F. D., and Oesterling, M. J., Analogies between urinary 17-ketosteroids and urinary "estroids," as determined microchemically. J. Clin. Endocrinol., 1948, 8, 295.

47. Deitrick, J. E., Whedon, G. D., and Shorr, E., Effects of immobilization upon various metabolic and physiologic functions of normal men. Am. J. Med., 1948, 4, 3.

48. Sandiford, I., Knowlton, K., and Kenyon, A. T., Basal heat production in hypogonadism in men and its increase by protracted treatment with testosterone propionate. J. Clin. Endocrinol., 1941, $1,931$.

49. Kenyon, A. T., The effect of testosterone propionate on the genitalia, prostate, secondary sex characters and body weight in eunuchoidism. Endocrinology, 1938, 23, 121.

50. Geist, S. H., Androgen therapy in the human female. J. Clin. Endocrinol., 1941, 1, 154.

51. Salmon, U. J., Rationale for androgen therapy in gynecology. J. Clin. Endocrinol., 1941, 1, 162.

52. Masters, W. H., and Grody, M. H., Estrogen-androgen substitution therapy in the aged female. II. Clinical response. Obs. \& Gynec., 1953, 2, 139.

53. Whedon, G. D., Steroid hormones in osteoporosis in Hormones and the Aging Process, Engle, E. T., and Pincus, G., Eds., New York, Academic Press, Inc., 1956, p. 221.

\section{APPENDIX A}

\section{Tables of Metabolic Balance Data}

Tables I-IX. Body Weight, Average Daily Urinary Creatinine, Creatine and Sulphur, and Nitrogen Balance (Patients D.Q., M.O'M., D.A., J.C., R.W., F.S., C.R., J.W. and R.V.K.)*

Tables X-XVIII. Average Daily Urinary Citric Acid, and Calcium and Phosphorus Balances (Patients D.Q., M.O’M., D.A., J.C., R.W., F.S., C.R., J.W. and R.V.K.)*

Table XIX. Lovett Method Examinations of Representative Muscle Groups Initially and at Six Months after Onset of Illness in Nine Patients with Paralytic Acute Anterior Poliomyelitis

* All excretion and balance data given in gm. per 24 hours. 
TABLE I

Patient D. Q.-Body weight, average daily urinary creatinine, creatine and sulphur, and nitrogen balance

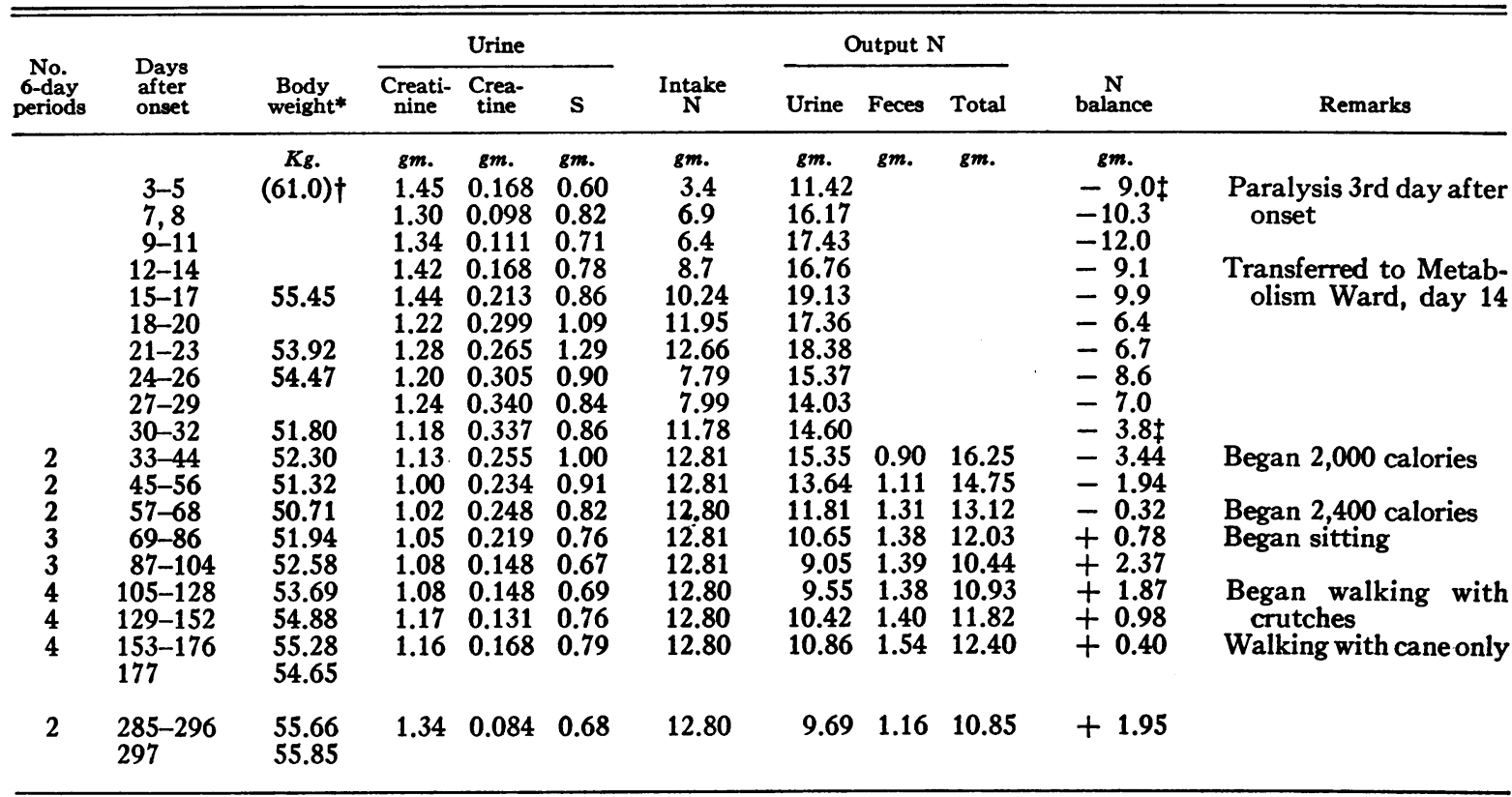

* Body weights at beginning of each set of days or metabolic periods.

+ Body weight prior to onset of illness.

$\ddagger N$ balances days 3 to 32 based on assumed daily fecal $N$ value of $1.00 \mathrm{gm}$., the average analyzed fecal $N$ loss during periods I through IV.

TABLE II

Patient M. O'M.-Body weight, average daily urinary creatinine, creatine and sulphur, andInitrogen balance

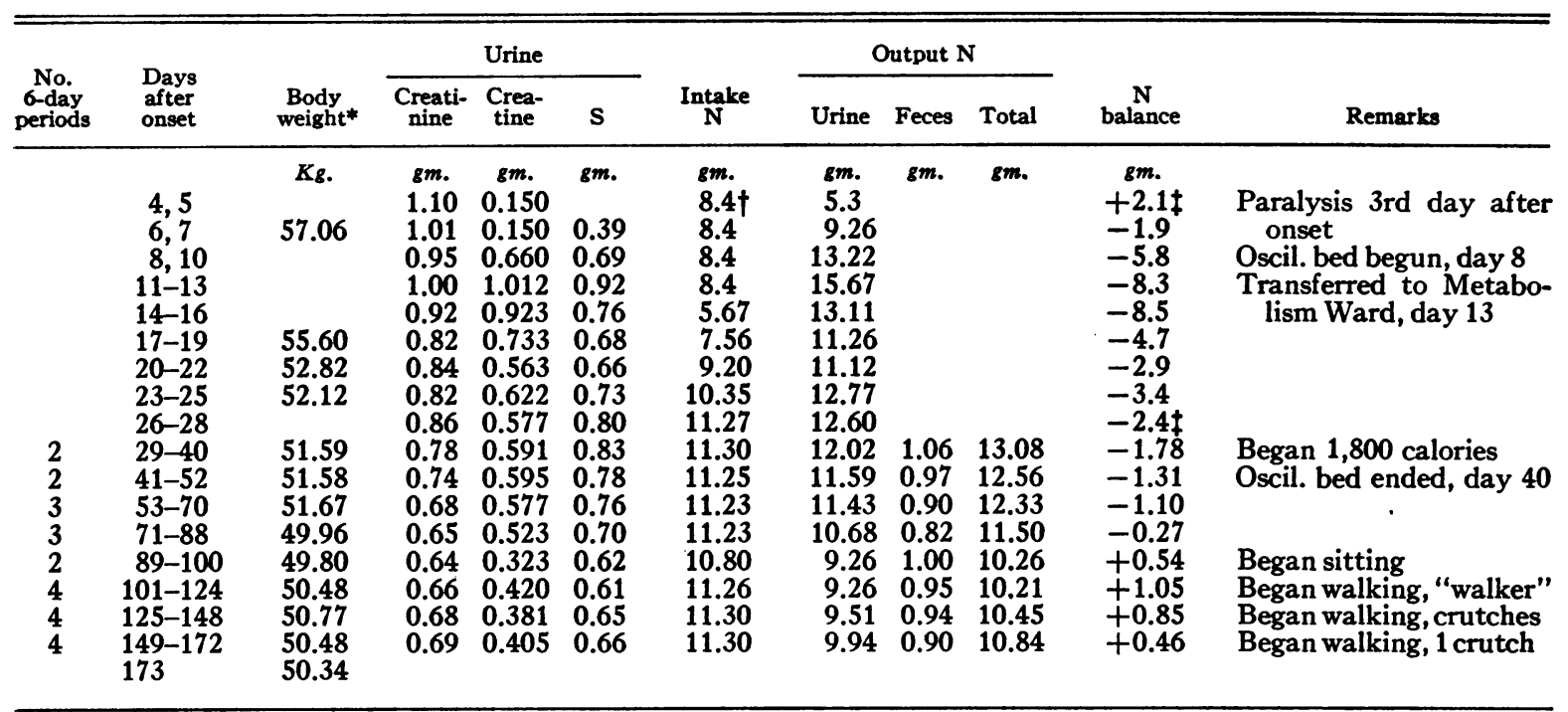

* Body weights at beginning of each set of days or metabolic periods.

t Approximate dietary intake days 4 to 13 , not constant.

$\ddagger N$ balances days 4 to 28 based on assumed daily fecal $N$ value of $1.02 \mathrm{gm}$., the average analyzed fecal $N$ loss during periods I through IV. 
TABLE III

Patient D. A.-Body weight, average daily urinary creatinine, creatine and sulphur, and nitrogen balance

\begin{tabular}{|c|c|c|c|c|c|c|c|c|c|c|c|}
\hline \multirow{2}{*}{$\begin{array}{c}\text { No. } \\
\text { 6-day } \\
\text { periods }\end{array}$} & \multirow{2}{*}{$\begin{array}{l}\text { Days } \\
\text { after } \\
\text { onset }\end{array}$} & \multirow[b]{2}{*}{$\underset{\text { weight* }}{\text { Body }}$} & \multicolumn{3}{|c|}{ Urine } & \multirow[b]{2}{*}{$\begin{array}{l}\text { Intake } \\
\mathbf{N}\end{array}$} & \multicolumn{3}{|c|}{ Output N } & \multirow[b]{2}{*}{$\begin{array}{c}\mathrm{N} \\
\text { balance }\end{array}$} & \multirow[b]{2}{*}{ Remarks } \\
\hline & & & $\begin{array}{c}\text { Creati- } \\
\text { nine }\end{array}$ & $\begin{array}{c}\text { Crea- } \\
\text { tine }\end{array}$ & $\mathbf{S}$ & & Urine & Feces & Total & & \\
\hline $\begin{array}{c}\text { (4-day) } \\
\text { (4-day) } \\
3 \\
2 \\
2 \\
2 \\
3 \\
3 \\
1 \\
2 \\
2 \\
3 \\
3 \\
3 \\
3 \\
3 \\
2 \\
2\end{array}$ & $\begin{array}{c}6,7 \\
8-10 \\
12,13 \\
14-16 \\
17,18 \\
19-22 \\
23-26 \\
27-44 \\
45-56 \\
57-68 \\
69-80 \\
81-98 \\
99-116 \\
117-122 \\
123-134 \\
135-146 \\
147-164 \\
165-182 \\
183-200 \\
201-218 \\
219-236 \\
237-248 \\
249-260 \\
261\end{array}$ & $\begin{array}{l}81.25 \\
79.76 \\
\\
79.25 \\
78.64 \\
78.60 \\
76.68 \\
77.03 \\
77.37 \\
80.43 \\
80.74 \\
78.95 \\
78.66 \\
77.59 \\
75.72 \\
76.05 \\
75.16 \\
75.75 \\
75.18 \\
72.12\end{array}$ & $\begin{array}{l}g m . \\
1.98 \\
1.93 \\
1.89 \\
1.75 \\
1.76 \\
1.46 \\
1.27 \\
1.26 \\
1.00 \\
0.98 \\
0.88 \\
0.90 \\
0.87 \\
0.86 \\
0.98 \\
0.92 \\
0.91 \\
0.83 \\
0.91 \\
0.92 \\
0.95 \\
0.90 \\
0.88\end{array}$ & $\begin{array}{c}g m . \\
0.110 \\
0.190 \\
0.829 \\
0.907 \\
1.580 \\
1.270 \\
0.997 \\
0.890 \\
0.958 \\
1.120 \\
0.850 \\
0.686 \\
0.573 \\
0.713 \\
1.016 \\
0.738 \\
0.587 \\
0.585 \\
0.633 \\
0.666 \\
0.811 \\
1.008 \\
0.866\end{array}$ & $\begin{array}{l}g m . \\
1.04 \\
1.26 \\
1.31 \\
1.48 \\
1.64 \\
1.38 \\
1.40 \\
1.08 \\
0.95 \\
1.00 \\
0.96 \\
0.88 \\
0.66 \\
0.64 \\
0.85 \\
0.92 \\
0.87 \\
0.85 \\
0.81 \\
0.80 \\
0.82 \\
0.86 \\
0.88\end{array}$ & $\begin{array}{l}g m . \\
10.7 \\
11.0 \\
11.5 \\
14.40 \\
14.37 \\
14.37 \\
14.36 \\
14.36 \\
14.37 \\
14.37 \\
14.34 \\
14.38 \\
14.37 \\
14.37 \\
14.37 \\
14.45 \\
14.38 \\
14.42 \\
14.40 \\
14.43 \\
14.42 \\
14.41\end{array}$ & $\begin{array}{c}g m . \\
18.80 \\
21.83 \\
24.45 \\
24.33 \\
27.75 \\
22.96 \\
20.90 \\
17.90 \\
14.64 \\
17.04 \\
14.84 \\
13.25 \\
10.32 \\
10.21 \\
13.80 \\
13.72 \\
13.98 \\
13.17 \\
12.87 \\
12.85 \\
13.04 \\
13.93 \\
14.00\end{array}$ & $\begin{array}{l}1.83 \\
1.83 \\
1.77 \\
1.78 \\
1.73 \\
1.62 \\
1.56 \\
1.63 \\
1.75 \\
1.60 \\
1.57 \\
1.25 \\
1.18 \\
1.29 \\
1.19 \\
1.18 \\
1.24 \\
1.32\end{array}$ & $\begin{array}{l}24.79 \\
22.73 \\
19.67 \\
16.42 \\
18.77 \\
16.46 \\
14.81 \\
11.95 \\
11.96 \\
15.40 \\
15.29 \\
15.23 \\
14.35 \\
14.16 \\
14.04 \\
14.22 \\
15.17 \\
15.32\end{array}$ & $\begin{array}{c}g m . \\
-13.0 \ddagger \\
-15.2 \\
-14.6 \\
-15.2 \ddagger \\
-10.42 \\
-8.35 \\
-5.31 \\
-2.06 \\
-4.40 \\
-2.09 \\
-0.47 \\
+2.43 \\
+2.41 \\
-1.03 \\
-0.92 \\
-0.78 \\
+0.03 \\
+0.26 \\
+0.36 \\
+0.21 \\
-0.75 \\
-0.91\end{array}$ & $\begin{array}{l}\text { Paralysis } 4 \text { th day after onset } \\
\text { Transferred to Metabolism } \\
\text { Ward, day } 16 \\
\text { Began } 2,800 \text { calories } \\
\text { Test. prop. } 25 \text { mgm. o.d. } \\
\text { Test. prop. } 50 \text { mgm. o.d. } \\
\text { Began sitting } \\
\text { T.p. } 25 \text { mgm.; estr.b. } 1.66 \text { mgm. } \\
\text { T.p. } 25 \text { mgm. ; estr.b. } 3.32 \text { mgm. } \\
\text { Began } 2,000 \text { calories } \\
\text { Began standing } \\
\text { Began walking, crutches } \\
\text { Estr.b. } 1.66 \text { mgm. o.d. } \\
\text { Estr.b. } 3.32 \text { mgm. o.d. }\end{array}$ \\
\hline
\end{tabular}

* Body weights at beginning of each set of days or metabolic periods.

$\dagger$ Body weight day before onset of illness.

$\ddagger \mathrm{N}$ balances days 8 to 18 based on assumed daily fecal $\mathrm{N}$ value of $1.80 \mathrm{gm}$., the average analyzed fecal $\mathrm{N}$ loss during periods I through IV.

TABLE IV

Patient J. C.-Body weight, average daily urinary creatinine, creatine and sulphur, and nitrogen balance

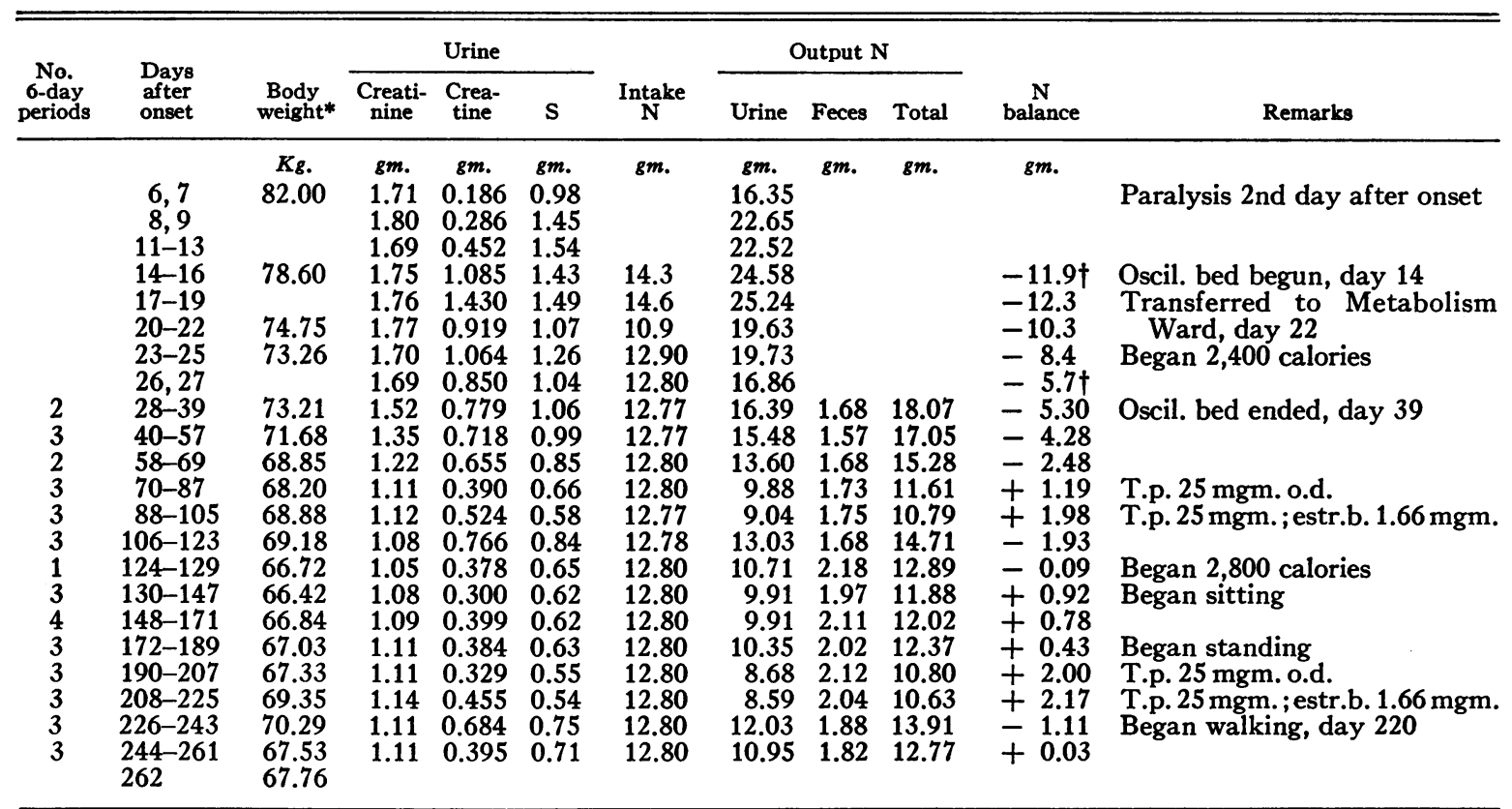

* Body weights at beginning of each set of days or metabolic periods.

$\dagger \mathrm{N}$ balances days 14 to 27 based on assumed daily fecal $\mathrm{N}$ value of $1.61 \mathrm{gm}$., the average analyzed fecal $\mathrm{N}$ loss of periods I through IV. 
TABLE V

Patient R. W.-Body weight, average daily urinary creatinine, creatine and sulphur, and nitrogen balance*; 7 :

\begin{tabular}{|c|c|c|c|c|c|c|c|c|c|c|c|}
\hline \multirow{2}{*}{$\begin{array}{l}\text { No. } \\
\text { 6-day } \\
\text { periods }\end{array}$} & \multirow{2}{*}{$\begin{array}{l}\text { Days } \\
\text { after } \\
\text { onset }\end{array}$} & \multirow[b]{2}{*}{$\begin{array}{c}\text { Body } \\
\text { weight } †\end{array}$} & \multicolumn{3}{|c|}{ Urine } & \multirow[b]{2}{*}{$\underset{\mathbf{N}}{\text { Intake }}$} & \multicolumn{3}{|c|}{ Output $\mathrm{N}$} & \multirow[b]{2}{*}{$\underset{\text { balance }}{\mathbf{N}}$} & \multirow[b]{2}{*}{ Remarks } \\
\hline & & & $\begin{array}{c}\text { Creati- } \\
\text { nine }\end{array}$ & $\begin{array}{c}\text { Crea- } \\
\text { tine }\end{array}$ & $\mathbf{s}$ & & Urine & Feces & Total & & \\
\hline $\begin{array}{l}3 \\
2 \\
2 \\
2 \\
2 \\
2 \\
3 \\
2 \\
3 \\
3 \\
3 \\
1 \\
2 \\
3 \\
2 \\
2 \\
2 \\
2 \\
2 \\
2\end{array}$ & $\begin{array}{c}19-21 \\
22-24 \\
25-27 \\
28-45 \\
46-57 \\
58-69 \\
70-81 \\
82-93 \\
94-105 \\
106-123 \\
124-135 \\
136-153 \\
154-171 \\
172-177 \\
178-189 \\
190-207 \\
208-219 \\
220-231 \\
232-243 \\
244-255 \\
256-267 \\
268-279 \\
280\end{array}$ & $\begin{array}{c}K g . \\
60.32 \\
60.00 \\
\\
58.55 \\
57.45 \\
56.40 \\
54.59 \\
53.51 \\
52.84 \\
53.49 \\
55.40 \\
53.76 \\
53.36 \\
54.50 \\
54.82 \\
55.28 \\
57.21 \\
56.29 \\
57.44 \\
59.33 \\
61.05 \\
59.80 \\
60.43\end{array}$ & $\begin{array}{l}g m . \\
1.35 \\
1.26 \\
1.14 \\
1.07 \\
0.96 \\
0.93 \\
0.93 \\
0.83 \\
0.78 \\
0.85 \\
0.85 \\
0.80 \\
0.77 \\
0.86 \\
0.84 \\
0.84 \\
0.85 \\
0.84 \\
0.86 \\
0.94 \\
0.96 \\
0.92\end{array}$ & $\begin{array}{l}g m . \\
1.316 \\
0.690 \\
0.725 \\
0.780 \\
0.732 \\
0.750 \\
0.707 \\
0.521 \\
0.490 \\
0.590 \\
0.823 \\
0.620 \\
0.522 \\
0.438 \\
0.464 \\
0.615 \\
0.564 \\
0.302 \\
0.256 \\
0.401 \\
0.574 \\
0.442\end{array}$ & $\begin{array}{l}g m . \\
1.30 \\
1.21 \\
1.19 \\
0.95 \\
0.82 \\
0.98 \\
0.89 \\
0.81 \\
0.84 \\
0.64 \\
0.85 \\
0.84 \\
0.80 \\
0.67 \\
0.72 \\
0.70 \\
0.78 \\
0.72 \\
0.60 \\
0.52 \\
0.68 \\
0.73\end{array}$ & $\begin{array}{c}g m . \\
12.72 \\
12.72 \\
12.72 \\
12.80 \\
12.80 \\
12.80 \\
12.78 \\
12.80 \\
12.80 \\
12.81 \\
12.81 \\
12.80 \\
12.78 \\
12.80 \\
12.79 \\
12.54 \\
12.80 \\
12.80 \\
12.79 \\
12.79 \\
12.80 \\
12.78\end{array}$ & $\begin{array}{r}\text { gm. } \\
22.36 \\
20.57 \\
18.45 \\
15.88 \\
13.60 \\
15.70 \\
14.68 \\
13.03 \\
12.26 \\
9.65 \\
12.96 \\
12.48 \\
11.79 \\
10.74 \\
10.65 \\
10.93 \\
11.93 \\
11.08 \\
8.92 \\
8.32 \\
10.96 \\
10.69\end{array}$ & $\begin{array}{l}g m . \\
1.15 \\
1.15 \\
1.23 \\
1.14 \\
0.96 \\
1.13 \\
1.13 \\
1.02 \\
1.09 \\
1.15 \\
1.21 \\
1.13 \\
1.37 \\
1.19 \\
1.54 \\
1.31 \\
1.16 \\
1.36 \\
1.37 \\
1.48 \\
1.55\end{array}$ & $\begin{array}{c}g m . \\
\\
21.72 \\
19.60 \\
17.11 \\
14.74 \\
16.66 \\
15.81 \\
14.16 \\
13.28 \\
10.74 \\
14.11 \\
13.69 \\
12.92 \\
12.11 \\
11.84 \\
12.47 \\
13.24 \\
12.24 \\
10.28 \\
9.69 \\
12.44 \\
12.24\end{array}$ & $\begin{array}{l}\text { gm. } \\
-10.8 \ddagger \\
-9.00 \\
-6.88 \\
-4.31 \\
-1.94 \\
=3.86 \\
=3.03 \\
-1.36 \\
-0.48 \\
+2.07 \\
=1.30 \\
=0.89 \\
=0.14 \\
+0.69 \\
+0.95 \\
+0.07 \\
+0.44 \\
+0.56 \\
+2.51 \\
+3.10 \\
+0.36 \\
+0.54\end{array}$ & $\begin{array}{l}\text { Began } 2,000 \text { calories, day } 23 \\
\text { Test. prop. } 25 \text { mgm. o.d. } \\
\text { Test. prop. } 25 \text { mgm. o.d. } \\
\text { Began sitting } \\
\text { Began } 2,400 \text { calories } \\
\text { T.p. } 25 \text { mgm. ; estr.b. } 1.66 \text { mgm. } \\
\text { Began walking } \\
\text { Began } 2,800 \text { calories } \\
\text { Estr.b. } 1.66 \text { mgm. o.d. } \\
\text { Test. prop. } 25 \text { mgm. o.d. } \\
\text { Test. prop. } 25 \text { mgm. o.d. }\end{array}$ \\
\hline
\end{tabular}

* Paralysis 1st day after onset; admitted directly to Metabolism Ward.

$\dagger$ Body weights at beginning of each set of days or metabolic periods.

$\ddagger N$ balance days 19 to 21 based on assumed daily fecal $N$ value of $1.15 \mathrm{gm}$., the average analyzed fecal $N$ loss during periods I through IV.

TABLE VI

Patient F. S.-Body weight, average daily urinary creatinine, creatine and sulphur, and nitrogen balance*

\begin{tabular}{|c|c|c|c|c|c|c|c|c|c|c|c|}
\hline \multirow{2}{*}{$\begin{array}{l}\text { No. } \\
\text { 6-day } \\
\text { periods }\end{array}$} & \multirow{2}{*}{$\begin{array}{l}\text { Days } \\
\text { after } \\
\text { onset }\end{array}$} & \multirow[b]{2}{*}{$\begin{array}{l}\text { Body } \\
\text { weight }\end{array}$} & \multicolumn{3}{|c|}{ Urine } & \multirow[b]{2}{*}{$\underset{\mathbf{N}}{\text { Intake }}$} & \multicolumn{3}{|c|}{ Output N } & \multirow[b]{2}{*}{$\stackrel{\mathrm{N}}{\text { balance }}$} & \multirow[b]{2}{*}{ Remarks } \\
\hline & & & $\begin{array}{c}\text { Creati- } \\
\text { nine }\end{array}$ & $\begin{array}{c}\text { Crea- } \\
\text { tine }\end{array}$ & $\mathbf{S}$ & & Urine & Feces & Total & & \\
\hline $\begin{array}{c}\text { (7-day) } \\
2 \\
3 \\
2 \\
2 \\
2 \\
3 \\
3 \\
2 \\
3 \\
2 \\
2 \\
3 \\
3 \\
2 \\
2 \\
2 \\
2 \\
2\end{array}$ & $\begin{array}{c}31-33 \\
34-40 \\
41-52 \\
53-70 \\
71-82 \\
83-94 \\
95-106 \\
107-124 \\
125-142 \\
143-154 \\
155-172 \\
173-184 \\
185-196 \\
197-214 \\
215-232 \\
233-244 \\
245-256 \\
257-268 \\
269-280 \\
281-292 \\
293\end{array}$ & $\begin{array}{c}\text { Kg. } \\
68.91 \\
69.47 \\
68.47 \\
68.56 \\
70.02 \\
69.37 \\
70.14 \\
69.13 \\
70.46 \\
70.43 \\
70.57 \\
73.61 \\
74.36 \\
74.92 \\
74.50 \\
73.50 \\
76.87 \\
77.85 \\
79.00 \\
77.85 \\
76.80\end{array}$ & $\begin{array}{l}g m . \\
1.20 \\
1.19 \\
1.04 \\
0.87 \\
0.72 \\
0.75 \\
0.68 \\
0.59 \\
0.59 \\
0.59 \\
0.66 \\
0.63 \\
0.64 \\
0.62 \\
0.64 \\
0.65 \\
0.69 \\
0.63 \\
0.71 \\
0.66\end{array}$ & $\begin{array}{l}\text { gm. } \\
0.980 \\
0.924 \\
0.742 \\
0.826 \\
0.754 \\
0.888 \\
0.725 \\
0.706 \\
0.760 \\
0.749 \\
0.764 \\
0.796 \\
0.938 \\
0.872 \\
0.780 \\
0.792 \\
0.952 \\
0.928 \\
0.886 \\
0.779\end{array}$ & $\begin{array}{l}g m . \\
1.07 \\
1.05 \\
0.93 \\
0.93 \\
0.91 \\
0.82 \\
0.84 \\
0.83 \\
0.84 \\
0.69 \\
0.70 \\
0.70 \\
0.81 \\
0.80 \\
0.66 \\
0.63 \\
0.72 \\
0.88 \\
0.92\end{array}$ & $\begin{array}{c}g m . \\
14.55 \\
14.40 \\
14.36 \\
14.40 \\
14.36 \\
14.43 \\
14.40 \\
14.38 \\
14.39 \\
14.38 \\
14.39 \\
14.38 \\
14.38 \\
14.39 \\
14.37 \\
14.40 \\
14.38 \\
14.38 \\
14.40 \\
14.37\end{array}$ & $\begin{array}{l}g m . \\
21.02 \\
19.82 \\
17.90 \\
15.54 \\
14.18 \\
15.10 \\
13.71 \\
13.16 \\
13.22 \\
12.50 \\
10.98 \\
11.14 \\
10.98 \\
13.35 \\
12.73 \\
10.66 \\
9.99 \\
10.54 \\
13.36 \\
14.14\end{array}$ & $\begin{array}{l}g m . \\
\\
1.54 \\
1.54 \\
1.72 \\
1.60 \\
1.71 \\
1.69 \\
1.54 \\
1.60 \\
1.71 \\
1.46 \\
1.44 \\
1.64 \\
1.37 \\
1.58 \\
1.45 \\
1.62 \\
1.42 \\
1.57 \\
1.78\end{array}$ & $\begin{array}{l}\text { gm. } \\
\\
21.36 \\
19.44 \\
17.26 \\
15.78 \\
16.81 \\
15.40 \\
14.70 \\
14.82 \\
14.21 \\
12.44 \\
12.58 \\
12.62 \\
14.72 \\
14.31 \\
12.11 \\
11.61 \\
11.96 \\
14.93 \\
15.92\end{array}$ & $\begin{array}{c}g m . \\
-8.1 \ddagger \\
-6.96 \\
-5.08 \\
-2.83 \\
-1.42 \\
-2.38 \\
-1.00 \\
-0.32 \\
-0.43 \\
+0.17 \\
+1.95 \\
+1.80 \\
+1.76 \\
-0.33 \\
+0.06 \\
+2.29 \\
+2.77 \\
+2.42 \\
-0.53 \\
-1.55\end{array}$ & $\begin{array}{l}\text { Began } 2,800 \text { calories } \\
\text { Oscillating bed } \\
\text { Oscillating bed } \\
\text { Oscillating bed } \\
\text { Test. prop. } 25 \text { mgm. o.d. } \\
\text { Test. prop. } 25 \text { mgm. o.d. } \\
\text { Test. prop. } 50 \text { mgm. o.d. } \\
\text { T.p. } 25 \text { mgm. ; estr.b. } 1.66 \mathrm{mgm} \text {. } \\
\text { T.p. } 25 \mathrm{mgm} . \text {; estr.b. } 1.66 \mathrm{mgm} \text {. } \\
\text { T.p. } 25 \mathrm{mgm} \text {.; estr.b. } 1.66 \mathrm{mgm} .\end{array}$ \\
\hline
\end{tabular}

* Paralysis 3rd day after onset; admitted directly to Metabolism Ward.

$\dagger$ Body weights at beginning of each set of days or metabolic periods.

$\ddagger N$ balance days 31 to 33 based on assumed daily fecal $N$ value of $1.63 \mathrm{gm}$., the average analyzed fecal $N$ loss during periods I through IV. 
TABLE VII

Patient C. R.-Body weight, average daily urinary creatinine, creatine and sulphur, and nitrogen balance *

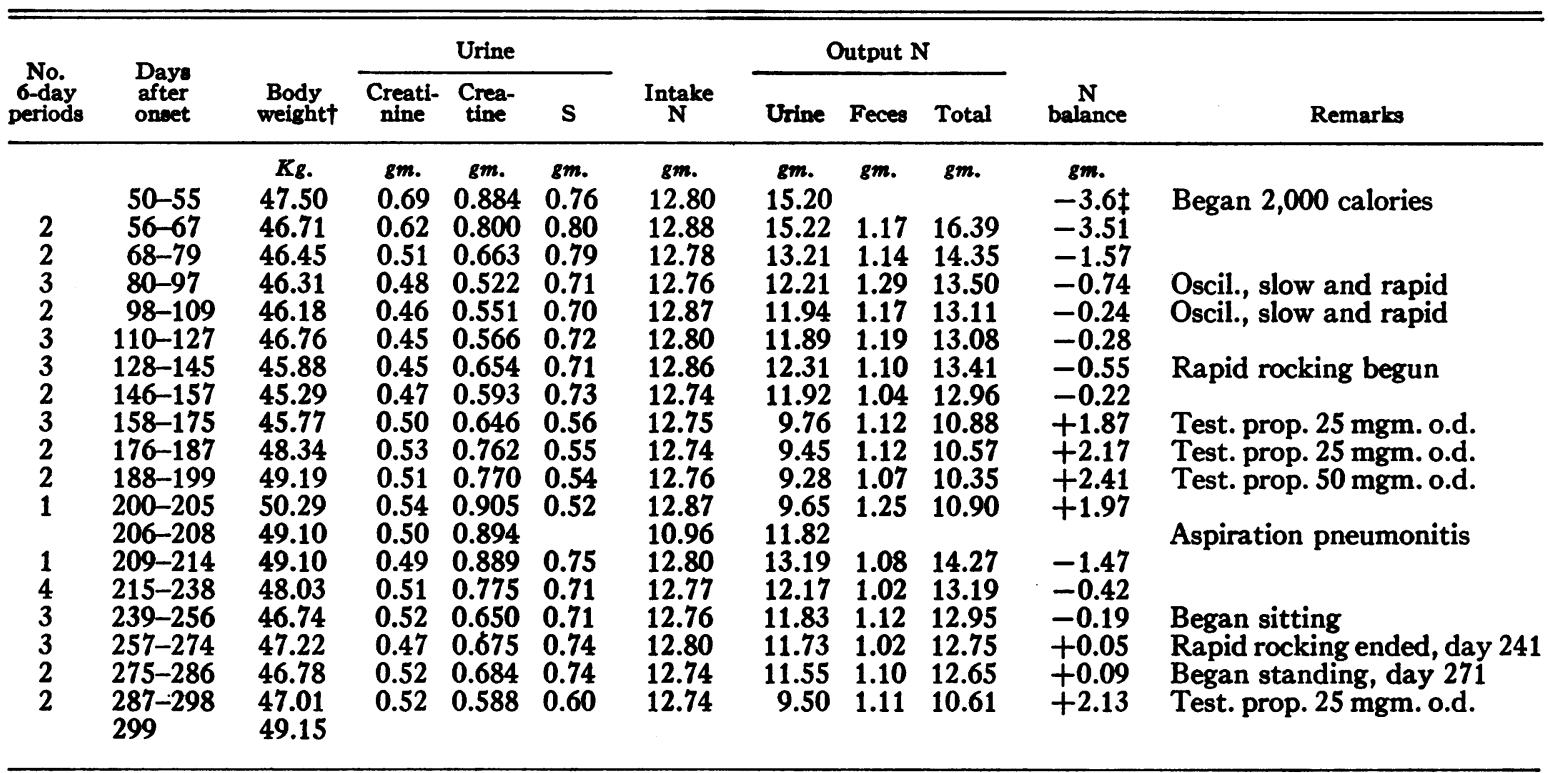

* Paralysis 1st day after onset; admitted directly to Metabolism Ward.

+ Body weights at beginning of each set of days or metabolic periods.

$\ddagger \mathrm{N}$ balance days 50 to 55 based on assumed daily fecal $\mathrm{N}$ value of $1.15 \mathrm{gm}$., the average analyzed fecal $\mathrm{N}$ loss during periods I through IV.

TABLE VIII

Patient J.W.-Body weight, average daily urinary creatinine, creatine and sulphur, and nitrogen balance

\begin{tabular}{|c|c|c|c|c|c|c|c|c|c|c|}
\hline \multirow{2}{*}{$\begin{array}{c}\text { No. } \\
\text { 6-day } \\
\text { periods }\end{array}$} & \multirow[b]{2}{*}{$\begin{array}{c}\text { Body } \\
\text { weight* }\end{array}$} & \multicolumn{3}{|c|}{ Urine } & \multirow[b]{2}{*}{$\underset{\mathbf{N}}{\text { Intake }}$} & \multicolumn{3}{|c|}{ Output $\mathbf{N}$} & \multirow[b]{2}{*}{$\underset{\text { balance }}{\mathbf{N}}$} & \multirow[b]{2}{*}{ Remarks } \\
\hline & & $\begin{array}{c}\text { Creati- } \\
\text { nine }\end{array}$ & $\begin{array}{c}\text { Crea- } \\
\text { tine }\end{array}$ & $\mathbf{S}$ & & Urine & Feces & Total & & \\
\hline $\begin{array}{l}3 \dagger \\
3 \dagger \\
3 \dagger \\
3 \dagger \\
3 \dagger \\
2 \\
3 \\
3\end{array}$ & $\begin{array}{c}K_{g} . \\
48.54 \\
48.50 \\
48.66 \\
48.26 \\
47.90 \\
47.85 \\
48.63 \\
48.31 \\
48.24\end{array}$ & $\begin{array}{l}g m . \\
0.50 \\
0.48 \\
0.49 \\
0.48 \\
0.55 \\
0.55 \\
0.56 \\
0.55\end{array}$ & $\begin{array}{l}\text { gm. } \\
0.545 \\
0.549 \\
0.594 \\
0.537 \\
0.494 \\
0.534 \\
0.686 \\
0.533\end{array}$ & $\begin{array}{l}\text { sm. } \\
0.65 \\
0.61 \\
0.57 \\
0.59 \\
0.57 \\
0.43 \\
0.55 \\
0.57\end{array}$ & $\begin{array}{c}8 m . \\
12.69 \\
12.83 \\
12.85 \\
12.60 \\
12.31 \\
12.85 \\
12.85 \\
12.85\end{array}$ & $\begin{array}{r}\text { sm. } \\
10.55 \\
10.29 \\
10.22 \\
10.40 \\
9.97 \\
7.86 \\
9.96 \\
10.51\end{array}$ & $\begin{array}{l}\text { gm. } \\
1.44 \\
1.34 \\
1.70 \\
1.55 \\
1.58 \\
1.80 \\
1.55 \\
1.57\end{array}$ & $\begin{array}{r}\text { gm. } \\
11.99 \\
11.63 \\
11.92 \\
11.95 \\
11.55 \\
9.66 \\
11.55 \\
12.08\end{array}$ & $\begin{array}{r}\text { gm. } \\
+0.70 \\
+1.20 \\
+0.93 \\
+0.65 \\
+0.76 \\
+3.19 \\
+1.34 \\
+0.77\end{array}$ & $\begin{array}{l}\text { Began } 1,800 \text { calories } \\
\text { Oscillating bed } \\
\text { Oscillating bed } \\
\text { Test. prop. } 50 \text { mgm. o.d. } \\
\text { Standing with braces }\end{array}$ \\
\hline
\end{tabular}

* Body weights at beginning of each set of days or metabolic periods.

† Seven-day periods. 
TABLE IX

Patient R. V.K.-Body weight, average daily urinary creatinine, creatine and sulphur, and nitrogen balance

\begin{tabular}{|c|c|c|c|c|c|c|c|c|c|c|}
\hline \multirow{2}{*}{$\begin{array}{c}\text { No. } \\
\text { 6-day } \\
\text { periods }\end{array}$} & \multirow[b]{2}{*}{$\begin{array}{c}\text { Body } \\
\text { weight }\end{array}$} & \multicolumn{3}{|c|}{ Urine } & \multirow[b]{2}{*}{$\begin{array}{l}\text { Intake } \\
\mathbf{N}\end{array}$} & \multicolumn{3}{|c|}{ Output $\mathbf{N}$} & \multirow[b]{2}{*}{$\underset{\text { balance }}{\mathrm{N}}$} & \multirow[b]{2}{*}{ Remarks } \\
\hline & & $\begin{array}{c}\text { Creati- } \\
\text { nine }\end{array}$ & $\underset{\text { tine }}{\text { Crea- }}$ & $\mathbf{s}$ & & Urine & Feces & Total & & \\
\hline $\begin{array}{l}3 \\
3 \\
4 \\
3 \\
3 \\
2 \\
3 \\
4 \\
2 \\
2 \\
2 \\
2 \\
2 \\
3\end{array}$ & $\begin{array}{c}K_{8 .} \\
28.30 \\
29.89 \\
30.62 \\
31.86 \\
31.92 \\
32.37 \\
32.04 \\
34.93 \\
33.98 \\
33.64 \\
34.42 \\
35.36 \\
37.01 \\
36.03 \\
36.69\end{array}$ & $\begin{array}{l}g m . \\
0.21 \\
0.22 \\
0.21 \\
0.21 \\
0.21 \\
0.20 \\
0.22 \\
0.22 \\
0.20 \\
0.20 \\
0.24 \\
0.23 \\
0.23 \\
0.23\end{array}$ & $\begin{array}{c}8 m . \\
0.611 \\
0.577 \\
0.601 \\
0.601 \\
0.626 \\
0.634 \\
0.740 \\
0.747 \\
0.744 \\
0.662 \\
0.778 \\
0.954 \\
0.903 \\
0.772\end{array}$ & $\begin{array}{l}g m . \\
0.43 \\
0.45 \\
0.46 \\
0.49 \\
0.50 \\
0.48 \\
0.37 \\
0.47 \\
0.60 \\
0.59 \\
0.56 \\
0.46 \\
0.52 \\
0.57\end{array}$ & $\begin{array}{r}\text { gm. } \\
9.35 \\
9.36 \\
9.35 \\
9.35 \\
9.36 \\
8.95 \\
9.36 \\
9.36 \\
12.04 \\
11.87 \\
12.10 \\
12.05 \\
11.42 \\
11.95\end{array}$ & $\begin{array}{l}8 m . \\
6.72 \\
7.14 \\
7.23 \\
7.40 \\
7.20 \\
7.56 \\
5.55 \\
7.45 \\
9.32 \\
9.24 \\
9.49 \\
7.63 \\
8.42 \\
9.92\end{array}$ & $\begin{array}{l}g m . \\
0.97 \\
1.05 \\
1.05 \\
1.05 \\
1.10 \\
1.00 \\
1.07 \\
1.09 \\
1.20 \\
1.10 \\
1.06 \\
1.13 \\
1.02 \\
0.95\end{array}$ & $\begin{array}{r}g m . \\
7.69 \\
8.19 \\
8.28 \\
8.45 \\
8.30 \\
8.56 \\
6.62 \\
8.54 \\
10.52 \\
10.34 \\
10.55 \\
8.76 \\
9.44 \\
10.87\end{array}$ & $\begin{array}{c}\text { sm. } \\
+1.66 \\
+1.17 \\
+1.07 \\
+0.90 \\
+1.06 \\
+0.39 \\
+2.74 \\
+0.82 \\
+1.52 \\
+1.53 \\
+1.55 \\
+3.29 \\
+1.98 \\
+1.08\end{array}$ & $\begin{array}{l}\text { Began } 1,595 \text { calories } \\
\text { Oscillating bed } \\
\text { Oscillating bed } \\
\text { Test. prop. } 50 \mathrm{mgm} \text {. o.d. } \\
\text { Began } 1,938 \text { calories } \\
\text { Estr. b. } 1.66 \mathrm{mgm} . \text { o.d. } \\
\text { Estr. b. } 1.66 \text { mgm.; t.p. } 50 \mathrm{mgm} \text {. } \\
\text { Standing with braces }\end{array}$ \\
\hline
\end{tabular}

* Body weights at beginning of each set of days or metabolic periods.

TABLE $X$

Patient D. Q.-Average daily urinary citric acid, and calcium and phosphorus balances

\begin{tabular}{|c|c|c|c|c|c|c|c|c|c|c|c|}
\hline \multirow{3}{*}{ 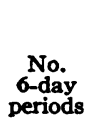 } & \multirow{3}{*}{$\begin{array}{l}\text { Days } \\
\text { after } \\
\text { onset }\end{array}$} & \multirow{3}{*}{$\begin{array}{l}\text { Citric } \\
\text { acid }\end{array}$} & \multicolumn{4}{|c|}{ Calcium } & \multicolumn{4}{|c|}{ Phosphorus } & \multirow[b]{3}{*}{ Remarks } \\
\hline & & & \multirow[b]{2}{*}{ Intake } & \multicolumn{2}{|c|}{ Output } & \multirow[b]{2}{*}{ Balance } & \multicolumn{3}{|c|}{ Output } & \multirow[b]{2}{*}{ Balance } & \\
\hline & & & & Urine & Feces & & Intake & Urine & Feces & & \\
\hline \multirow{5}{*}{$\begin{array}{l}2 \\
2 \\
2 \\
3 \\
3 \\
3 \\
4 \\
4 \\
4 \\
4\end{array}$} & \multirow{5}{*}{$\begin{array}{c}3-8 \\
9-14 \\
15-20 \\
21-26 \\
27-32 \\
33-44 \\
45-56 \\
57-68 \\
69-86 \\
87-104 \\
105-128 \\
129-152 \\
153-176\end{array}$} & $\begin{array}{l}8 m . \\
0.374 \\
0.568 \\
0.382 \\
0.340 \\
0.406\end{array}$ & \multirow{5}{*}{$\begin{array}{l}g m . \\
0.505 \\
0.940 \\
1.260 \\
0.660 \\
0.985 \\
0.920 \\
0.920 \\
0.920 \\
0.921 \\
0.921 \\
0.921 \\
0.920 \\
0.921\end{array}$} & \multirow{5}{*}{$\begin{array}{l}g m . \\
0.186 \\
0.216 \\
0.376 \\
0.404 \\
0.368 \\
0.443 \\
0.447 \\
0.404 \\
0.351 \\
0.274 \\
0.200 \\
0.151 \\
0.124\end{array}$} & $8 m$. & sm. & \multirow{5}{*}{$\begin{array}{c}8 m . \\
0.605 \\
1.005 \\
1.525 \\
1.080 \\
1.285 \\
1.414 \\
1.416 \\
1.463 \\
1.459 \\
1.462 \\
1.462 \\
1.462 \\
1.463\end{array}$} & \multirow{5}{*}{$\begin{array}{c}8 m . \\
1.052 \\
1.200 \\
1.358 \\
1.165 \\
0.995 \\
1.016 \\
0.975 \\
0.925 \\
0.898 \\
0.798 \\
0.814 \\
0.829 \\
0.874\end{array}$} & gm. & $g m$. & $\begin{array}{l}\text { Paralysis 3rd day after onset } \\
\text { Transferred to Metabolism } \\
\text { Ward, day } 14\end{array}$ \\
\hline & & $\begin{array}{l}0.492 \\
0.438\end{array}$ & & & \multirow{4}{*}{$\begin{array}{l}0.810 \\
0.823 \\
0.772 \\
0.774 \\
0.769 \\
0.768 \\
0.801 \\
0.818\end{array}$} & \multirow{4}{*}{$\begin{array}{l}-0.333 \\
-0.350 \\
-0.256 \\
-0.204 \\
-0.122 \\
-0.047 \\
-0.032 \\
-0.021\end{array}$} & & & \multirow{4}{*}{$\begin{array}{l}0.532 \\
0.477 \\
0.452 \\
0.479 \\
0.445 \\
0.429 \\
0.464 \\
0.467\end{array}$} & \multirow{4}{*}{$\begin{array}{l}-0.134 \\
-0.036 \\
+0.086 \\
+0.082 \\
+0.219 \\
+0.219 \\
+0.169 \\
+0.122\end{array}$} & Began 2,000 calories \\
\hline & & $\begin{array}{l}0.357 \\
0.342\end{array}$ & & & & & & & & & $\begin{array}{l}\text { Began } 2,400 \text { calories } \\
\text { Began sitting }\end{array}$ \\
\hline & & $\begin{array}{l}0.422 \\
0.510\end{array}$ & & & & & & & & & Began walking with crutches \\
\hline & & 0.414 & & & & & & & & & Walking with cane only \\
\hline 22 & 285-296 & 0.542 & 0.921 & 0.228 & 0.600 & +0.093 & 1.462 & 0.837 & 0.430 & +0.195 & \\
\hline
\end{tabular}


TABLE XI

Patient M. O'M.-Average daily urinary citric acid, and calcium and phosphorus balances

\begin{tabular}{|c|c|c|c|c|c|c|c|c|c|c|c|}
\hline \multirow{3}{*}{$\begin{array}{l}\text { No. } \\
\text { 6-day } \\
\text { periods }\end{array}$} & \multirow{3}{*}{$\begin{array}{l}\text { Days } \\
\text { after } \\
\text { onset }\end{array}$} & \multirow{3}{*}{$\begin{array}{l}\text { Citric } \\
\text { acid }\end{array}$} & \multicolumn{4}{|c|}{ Calcium } & \multicolumn{4}{|c|}{ Phosphorus } & \multirow[b]{3}{*}{ Remarks } \\
\hline & & & \multirow[b]{2}{*}{ Intake } & \multicolumn{2}{|c|}{ Output } & \multirow[b]{2}{*}{ Balance } & \multirow[b]{2}{*}{ Intake } & \multicolumn{2}{|c|}{ Output } & \multirow[b]{2}{*}{ Balance } & \\
\hline & & & & Urine & Feces & & & Urine & Feces & & \\
\hline $\begin{array}{ll}2 & \\
2 & \\
3 & \\
3 & \\
2 & \\
4 & 1 \\
4 & 1 \\
4 & 1\end{array}$ & $\begin{array}{c}4-7 \\
8-13 \\
14-22 \\
23-28 \\
29-40 \\
41-52 \\
53-70 \\
71-88 \\
89-100 \\
101-124 \\
125-148 \\
149-172\end{array}$ & $\begin{array}{l}g m . \\
0.380 \\
0.568 \\
0.771 \\
0.892 \\
0.926 \\
1.016 \\
0.947\end{array}$ & $\begin{array}{l}\text { gm. } \\
1.162 * \\
1.162 \\
0.877 \\
0.930 \\
0.921 \\
0.921 \\
0.921 \\
0.921 \\
0.908 \\
0.921 \\
0.921 \\
0.921\end{array}$ & $\begin{array}{l}g m . \\
0.203 \\
0.264 \\
0.247 \\
0.337 \\
0.370 \\
0.334 \\
0.358 \\
0.352 \\
0.270 \\
0.250 \\
0.206 \\
0.180\end{array}$ & $\begin{array}{l}0.845 \\
0.972 \\
1.012 \\
0.826 \\
0.912 \\
0.904 \\
0.917 \\
0.908\end{array}$ & $\begin{array}{l}-0.294 \\
-0.385 \\
-0.449 \\
-0.257 \\
-0.274 \\
-0.233 \\
-0.202 \\
-0.167\end{array}$ & $\begin{array}{l}\text { gm. } \\
1.057^{*} \\
1.057 \\
0.992 \\
1.314 \\
1.354 \\
1.356 \\
1.356 \\
1.355 \\
1.311 \\
1.356 \\
1.355 \\
1.356\end{array}$ & $\begin{array}{l}\text { gm. } \\
0.632 \\
0.890 \\
0.752 \\
0.836 \\
0.791 \\
0.802 \\
0.819 \\
0.758 \\
0.660 \\
0.703 \\
0.730 \\
0.718\end{array}$ & $\begin{array}{l}0.584 \\
0.616 \\
0.687 \\
0.578 \\
0.644 \\
0.617 \\
0.550 \\
0.612\end{array}$ & $\begin{array}{r}-0.021 \\
-0.062 \\
-0.150 \\
+0.019 \\
+0.007 \\
+0.036 \\
+0.075 \\
+0.026\end{array}$ & $\begin{array}{l}\text { Paralysis, day } 3 \\
\text { Oscil. bed begun, day } 8 \\
\text { Transferred to Metabolism } \\
\text { Ward, day } 13 \\
\text { Began 1,800 calories } \\
\text { Oscil. bed ended, day } 40 \\
\\
\text { Began sitting } \\
\text { Began walking, "walker" } \\
\text { Began walking, crutches } \\
\text { Began walking, 1 crutch }\end{array}$ \\
\hline
\end{tabular}

* Approximate dietary intake days 4 to 13 , not constant.

TABLE XII

Patient D. A.-Average daily urinary citric acid, and calcium and phosphorus balances

\begin{tabular}{|c|c|c|c|c|c|c|c|c|c|c|c|}
\hline \multirow{3}{*}{$\begin{array}{l}\text { No. } \\
\text { G-day } \\
\text { periods }\end{array}$} & \multirow{3}{*}{$\begin{array}{l}\text { Days } \\
\text { after } \\
\text { onset }\end{array}$} & \multirow{3}{*}{$\begin{array}{c}\text { Citric } \\
\text { acid }\end{array}$} & \multicolumn{4}{|c|}{ Calcium } & \multicolumn{4}{|c|}{ Phosphorus } & \multirow[b]{3}{*}{ Remarks } \\
\hline & & & \multirow[b]{2}{*}{ Intake } & \multicolumn{2}{|c|}{ Output } & \multirow[b]{2}{*}{ Balance } & \multirow[b]{2}{*}{ Intake } & \multicolumn{2}{|c|}{ Output } & \multirow[b]{2}{*}{ Balance } & \\
\hline & & & & Urine & Feces & & & Urine & Feces & & \\
\hline $\begin{array}{l}3 \\
2 \\
2 \\
2 \\
\mathbf{3} \\
3 \\
1 \\
2 \\
2 \\
\mathbf{3} \\
\mathbf{3} \\
\mathbf{3} \\
\mathbf{3} \\
\mathbf{3} \\
\mathbf{2} \\
\mathbf{2}\end{array}$ & $\begin{array}{c}6,7 \\
8-13 \\
14-18 \\
19-26 \\
27-44 \\
45-56 \\
57-68 \\
69-80 \\
81-98 \\
99-116 \\
117-122 \\
123-134 \\
135-146 \\
147-164 \\
165-182 \\
183-200 \\
201-218 \\
219-236 \\
237-248 \\
249-260\end{array}$ & $\begin{array}{c}g m . \\
0.662 \\
0.542 \\
0.586 \\
0.364 \\
0.371 \\
0.308 \\
0.328 \\
0.264 \\
0.478 \\
0.475 \\
0.423 \\
0.680 \\
0.499 \\
0.432 \\
0.427 \\
0.502 \\
0.469 \\
0.820 \\
0.975 \\
0.915\end{array}$ & $\begin{array}{l}\text { gm. } \\
\\
1.127 \\
1.084 \\
0.920 \\
0.920 \\
0.920 \\
0.920 \\
0.921 \\
0.920 \\
0.921 \\
0.920 \\
0.920 \\
0.920 \\
0.920 \\
0.920 \\
0.920 \\
0.919 \\
0.920 \\
0.920 \\
0.920\end{array}$ & $\begin{array}{c}g m . \\
0.270 \\
0.338 \\
0.383 \\
0.392 \\
0.445 \\
0.364 \\
0.308 \\
0.317 \\
0.298 \\
0.250 \\
0.217 \\
0.184 \\
0.193 \\
0.191 \\
0.191 \\
0.172 \\
0.148 \\
0.184 \\
0.186 \\
0.146\end{array}$ & $\begin{array}{l}0.802 \\
0.742 \\
0.793 \\
0.706 \\
0.746 \\
0.716 \\
0.782 \\
0.728 \\
0.668 \\
0.672 \\
0.753 \\
0.716 \\
0.810 \\
0.760 \\
0.763 \\
0.690 \\
0.746\end{array}$ & $\begin{array}{l}-0.274 \\
-0.267 \\
-0.237 \\
-0.094 \\
-0.142 \\
-0.094 \\
-0.111 \\
-0.025 \\
+0.068 \\
+0.055 \\
-0.024 \\
+0.013 \\
-0.062 \\
+0.011 \\
-0.027 \\
+0.044 \\
+0.028\end{array}$ & $\begin{array}{c}g m . \\
1.492 \\
1.650 \\
1.622 \\
1.642 \\
1.631 \\
1.642 \\
1.625 \\
1.638 \\
1.639 \\
1.646 \\
1.647 \\
1.634 \\
1.547 \\
1.547 \\
1.546 \\
1.543 \\
1.547 \\
1.546 \\
1.545\end{array}$ & $\begin{array}{c}g m . \\
1.178 \\
2.012 \\
2.090 \\
1.770 \\
1.342 \\
1.090 \\
1.265 \\
1.118 \\
1.012 \\
0.859 \\
0.864 \\
1.092 \\
0.996 \\
1.004 \\
0.951 \\
0.995 \\
0.872 \\
0.952 \\
1.048 \\
1.062\end{array}$ & $\begin{array}{l}0.490 \\
0.497 \\
0.536 \\
0.518 \\
0.517 \\
0.514 \\
0.499 \\
0.507 \\
0.490 \\
0.484 \\
0.500 \\
0.479 \\
0.513 \\
0.542 \\
0.520 \\
0.478 \\
0.534\end{array}$ & $\begin{array}{r}-0.638 \\
-0.197 \\
+0.005 \\
-0.141 \\
-0.010 \\
+0.112 \\
+0.281 \\
+0.275 \\
+0.065 \\
+0.154 \\
+0.043 \\
+0.117 \\
+0.038 \\
+0.129 \\
+0.075 \\
+0.020 \\
-0.051\end{array}$ & $\begin{array}{l}\text { Paralysis, day } 4 \\
\text { Transferred to Metabolism } \\
\text { Ward, day } 16 \\
\text { Began 2,800 calories, day } 17 \\
\text { Test. prop. } 25 \mathrm{mgm} \text {. 0.d. } \\
\text { Test. prop. } 50 \mathrm{mgm} \text {. o.d. } \\
\text { Began sitting } \\
\text { T.p. } 25 \text { mgm.; estr.b. } 1.66 \mathrm{mgm} \text {. } \\
\text { T.p. } 25 \text { mgm. ; estr.b. } 3.22 \mathrm{mgm} \text {. } \\
\text { Began } 2,000 \text { calories } \\
\text { Began standing } \\
\text { Began walking, crutches } \\
\text { Estr.b. } 1.66 \text { mgm. o.d. } \\
\text { Estr.b. 3.32 mgm. o.d. }\end{array}$ \\
\hline
\end{tabular}


TABLE XIII

Patient J. C.-Average daily urinary citric acid, and calcium and phosphorus balances

\begin{tabular}{|c|c|c|c|c|c|c|c|c|c|c|c|}
\hline \multirow{3}{*}{$\begin{array}{l}\text { No. } \\
\text { 6-day } \\
\text { periods }\end{array}$} & \multirow{3}{*}{$\begin{array}{l}\text { Days } \\
\text { after } \\
\text { onset }\end{array}$} & \multirow{3}{*}{$\begin{array}{l}\text { Citric } \\
\text { acid }\end{array}$} & \multicolumn{4}{|c|}{ Calcium } & \multicolumn{4}{|c|}{ Phosphorus } & \multirow[b]{3}{*}{ Remarks } \\
\hline & & & \multirow[b]{2}{*}{ Intake } & \multicolumn{2}{|c|}{ Output } & \multirow[b]{2}{*}{ Balance } & \multirow[b]{2}{*}{ Intake } & \multicolumn{2}{|c|}{ Output } & \multirow[b]{2}{*}{ Balance } & \\
\hline & & & & Urine & Feces & & & Urine & Feces & & \\
\hline $\begin{array}{l}2 \\
3 \\
2 \\
3 \\
3 \\
3 \\
1 \\
3 \\
4 \\
4 \\
3 \\
3 \\
3 \\
3 \\
3\end{array}$ & $\begin{array}{l}6,7 \\
8-13 \\
14-16 \\
17-22 \\
23-27 \\
28-39 \\
40-57 \\
58-69 \\
70-87 \\
88-105 \\
106-123 \\
124-129 \\
130-147 \\
148-171 \\
172-189 \\
190-207 \\
208-225 \\
226-243 \\
244-261\end{array}$ & $\begin{array}{c}\boldsymbol{g} m . \\
\mathbf{0 . 3 8 1} \\
0.726 \\
0.732 \\
0.738 \\
0.594 \\
\mathbf{0 . 5 9 0} \\
\mathbf{0 . 5 9 1} \\
\mathbf{0 . 6 3 6} \\
\mathbf{0 . 6 5 8} \\
0.806 \\
0.763 \\
0.772 \\
0.815 \\
0.867 \\
0.871 \\
0.717 \\
0.738 \\
0.768 \\
0.632\end{array}$ & $\begin{array}{l}1.208 \\
1.072 \\
0.919 \\
0.920 \\
0.919 \\
0.919 \\
0.919 \\
0.919 \\
0.919 \\
0.921 \\
0.921 \\
0.921 \\
0.921 \\
0.920 \\
0.921 \\
0.921 \\
0.921\end{array}$ & $\begin{array}{c}g m . \\
0.214 \\
0.334 \\
0.451 \\
0.564 \\
0.500 \\
0.534 \\
0.512 \\
0.502 \\
0.432 \\
0.330 \\
0.364 \\
0.300 \\
0.288 \\
0.235 \\
0.229 \\
0.168 \\
0.130 \\
0.134 \\
0.160\end{array}$ & $\begin{array}{l}0.771 \\
0.826 \\
0.924 \\
0.922 \\
0.881 \\
0.888 \\
0.878 \\
0.811 \\
0.859 \\
0.832 \\
0.836 \\
0.801 \\
0.752 \\
0.722\end{array}$ & $\begin{array}{l}-0.385 \\
-0.419 \\
-0.507 \\
-0.435 \\
-0.292 \\
-0.333 \\
-0.257 \\
-0.178 \\
-0.173 \\
-0.140 \\
-0.084 \\
-0.010 \\
+0.035 \\
+0.039\end{array}$ & $\begin{array}{l}1.722 \\
1.483 \\
1.442 \\
1.434 \\
1.434 \\
1.442 \\
1.438 \\
1.436 \\
1.437 \\
1.425 \\
1.423 \\
1.423 \\
1.422 \\
1.426 \\
1.423 \\
1.423 \\
1.426\end{array}$ & $\begin{array}{l}g m . \\
0.997 \\
1.764 \\
1.990 \\
1.616 \\
1.361 \\
1.432 \\
1.295 \\
1.098 \\
0.926 \\
0.869 \\
1.123 \\
0.848 \\
0.862 \\
0.873 \\
0.885 \\
0.759 \\
0.791 \\
1.009 \\
0.892\end{array}$ & $\begin{array}{l}\mathbf{0 . 5 4 0} \\
\mathbf{0 . 6 0 0} \\
\mathbf{0 . 5 8 8} \\
\mathbf{0 . 5 7 4} \\
\mathbf{0 . 5 0 7} \\
\mathbf{0 . 5 2 3} \\
\mathbf{0 . 5 3 5} \\
\mathbf{0 . 4 9 8} \\
\mathbf{0 . 5 3 6} \\
\mathbf{0 . 4 9 0} \\
\mathbf{0 . 5 0 9} \\
\mathbf{0 . 4 8 6} \\
\mathbf{0 . 4 6 2} \\
\mathbf{0 . 4 5 0}\end{array}$ & $\begin{array}{r}-0.538 \\
-0.461 \\
-0.244 \\
-0.062 \\
+0.060 \\
-0.209 \\
+0.042 \\
+0.063 \\
+0.014 \\
+0.047 \\
+0.158 \\
+0.146 \\
-0.048 \\
+0.084\end{array}$ & $\begin{array}{l}\text { Paralysis, day } 2 \\
\text { Oscil. bed begun, day } 14 \\
\text { Metabolism Ward, day } 22 \\
\text { Began } 2,400 \text { calories } \\
\text { Oscil. bed ended, day } 39 \\
\text { T.p. } 25 \text { mgm. o.d. } \\
\text { T.p. } 25 \text { mgm.; estr.b. } 1.66 \text { mgm. } \\
\text { Began } 2,800 \text { calories } \\
\text { Began sitting } \\
\text { Began standing } \\
\text { T.p. } 25 \text { mgm. o.d. } \\
\text { T.p. } 25 \text { mgm.; estr.b. } 1.66 \text { mgm. } \\
\text { Began walking, day } 220\end{array}$ \\
\hline
\end{tabular}

TABLE XIV

Patient R. W.-Average daily urinary citric acid, and calcium and phosphorus balances

\begin{tabular}{|c|c|c|c|c|c|c|c|c|c|c|c|}
\hline \multirow{3}{*}{$\begin{array}{c}\text { No. } \\
\text { 6-day } \\
\text { periods }\end{array}$} & \multirow{3}{*}{$\begin{array}{l}\text { Days } \\
\text { after } \\
\text { onset }\end{array}$} & \multirow{3}{*}{$\begin{array}{l}\text { Citric } \\
\text { acid }\end{array}$} & \multicolumn{4}{|c|}{ Calcium } & \multicolumn{4}{|c|}{ Phosphorus } & \multirow[b]{3}{*}{ Remarks } \\
\hline & & & \multirow[b]{2}{*}{ Intake } & \multicolumn{2}{|c|}{ Output } & \multirow[b]{2}{*}{ Balance } & \multirow[b]{2}{*}{ Intake } & \multicolumn{2}{|c|}{ Output } & \multirow[b]{2}{*}{ Balance } & \\
\hline & & & & Urine & Feces & & & Urine & Feces & & \\
\hline $\begin{array}{l}3 \\
2 \\
2 \\
2 \\
2 \\
2 \\
2 \\
2 \\
3 \\
2 \\
3 \\
3 \\
1 \\
2 \\
3 \\
2 \\
2 \\
2 \\
2 \\
2 \\
2 \\
2\end{array}$ & $\begin{array}{c}19-21 \\
22-27 \\
28-45 \\
46-57 \\
58-69 \\
70-81 \\
82-93 \\
94-105 \\
106-123 \\
124-135 \\
135-153 \\
154-171 \\
172-177 \\
178-189 \\
190-207 \\
208-219 \\
220-231 \\
232-243 \\
244-255 \\
256-267 \\
268-279\end{array}$ & $\begin{array}{c}g m . \\
0.407 \\
0.381 \\
0.241 \\
0.160 \\
0.268 \\
0.355 \\
0.304 \\
0.400 \\
0.463 \\
0.572 \\
0.416 \\
0.473 \\
0.480 \\
0.480 \\
0.841 \\
0.702 \\
0.464 \\
0.415 \\
0.390 \\
0.440\end{array}$ & $\begin{array}{l}\boldsymbol{g} \boldsymbol{m} . \\
0.912 \\
0.920 \\
0.920 \\
0.919 \\
0.920 \\
0.920 \\
0.920 \\
0.920 \\
0.920 \\
0.920 \\
0.920 \\
0.921 \\
0.920 \\
0.902 \\
0.921 \\
0.920 \\
0.920 \\
0.920 \\
0.920 \\
0.920\end{array}$ & $\begin{array}{c}\text { gm. } \\
0.566 \\
0.648 \\
0.581 \\
0.470 \\
0.454 \\
0.485 \\
0.466 \\
0.429 \\
0.308 \\
0.227 \\
0.266 \\
0.274 \\
0.265 \\
0.242 \\
0.184 \\
0.192 \\
0.183 \\
0.188 \\
0.184 \\
0.164 \\
0.198\end{array}$ & $\begin{array}{l}g m . \\
0.706 \\
0.828 \\
0.803 \\
0.712 \\
0.810 \\
0.912 \\
0.856 \\
0.813 \\
0.784 \\
0.866 \\
0.834 \\
0.863 \\
0.787 \\
0.748 \\
0.885 \\
0.812 \\
0.820 \\
0.748 \\
0.768 \\
0.744\end{array}$ & $\begin{array}{c}g m . \\
-0.442 \\
-0.489 \\
-0.353 \\
-0.247 \\
-0.375 \\
-0.458 \\
-0.365 \\
-0.201 \\
-0.091 \\
-0.212 \\
-0.188 \\
-0.207 \\
-0.109 \\
-0.030 \\
-0.156 \\
-0.075 \\
-0.088 \\
-0.012 \\
-0.012 \\
-0.022\end{array}$ & $\begin{array}{l}g m . \\
\\
1.359 \\
1.357 \\
1.366 \\
1.352 \\
1.345 \\
1.353 \\
1.432 \\
1.436 \\
1.435 \\
1.433 \\
1.430 \\
1.450 \\
1.454 \\
1.419 \\
1.451 \\
1.453 \\
1.452 \\
1.453 \\
1.453 \\
1.454\end{array}$ & $\begin{array}{c}\text { gm. } \\
1.540 \\
1.330 \\
1.087 \\
1.036 \\
1.156 \\
1.078 \\
0.978 \\
0.980 \\
0.780 \\
1.052 \\
0.952 \\
0.902 \\
0.845 \\
0.887 \\
0.787 \\
0.906 \\
0.826 \\
0.742 \\
0.784 \\
0.984 \\
0.902\end{array}$ & $\begin{array}{l}g m . \\
0.504 \\
0.546 \\
0.516 \\
0.458 \\
0.511 \\
0.561 \\
0.526 \\
0.523 \\
0.497 \\
0.530 \\
0.563 \\
0.550 \\
0.514 \\
0.578 \\
0.593 \\
0.540 \\
0.521 \\
0.475 \\
0.494 \\
0.506\end{array}$ & $\begin{array}{c}g m . \\
-0.475 \\
-0.276 \\
-0.186 \\
-0.262 \\
-0.244 \\
-0.186 \\
-0.074 \\
+0.133 \\
-0.114 \\
-0.049 \\
-0.035 \\
+0.055 \\
+0.053 \\
+0.054 \\
-0.048 \\
+0.087 \\
+0.189 \\
+0.194 \\
+0.025 \\
+0.046\end{array}$ & $\begin{array}{l}\text { Began } 2,000 \text { calories, day } 23 \\
\text { Test. prop. } 25 \text { mgm. o.d. } \\
\text { Test. prop. } 25 \text { mgm. o.d. } \\
\text { Began gitting } \\
\text { Began } 2,400 \text { calories } \\
\text { T.p. } 25 \text { mgm.; estr.b. } 1.66 \text { mgm. } \\
\text { Began walking } \\
\text { Began } 2,800 \text { calories } \\
\text { Estr.b. } 1.66 \text { mgm. o.d. } \\
\text { Test. prop. } 25 \text { mgm. o.d. } \\
\text { Test. prop. } 25 \text { mgm. o.d. }\end{array}$ \\
\hline
\end{tabular}


TABLE XV

Patient F. S.-Average daily urinary citric acid, and calcium and phosphorus balances

\begin{tabular}{|c|c|c|c|c|c|c|c|c|c|c|c|}
\hline \multirow{3}{*}{$\begin{array}{c}\text { No. } \\
\text { 6-day } \\
\text { periods }\end{array}$} & \multirow{3}{*}{$\begin{array}{l}\text { Days } \\
\text { after } \\
\text { onset }\end{array}$} & \multirow{3}{*}{$\begin{array}{l}\text { Citric } \\
\text { acid }\end{array}$} & \multicolumn{4}{|c|}{ Calcium } & \multicolumn{4}{|c|}{ Phosphorus } & \multirow[b]{3}{*}{ Remarks } \\
\hline & & & \multirow[b]{2}{*}{ Intake } & \multicolumn{2}{|c|}{ Output } & \multirow[b]{2}{*}{ Balance } & \multirow[b]{2}{*}{ Intake } & \multicolumn{2}{|c|}{ Output } & \multirow[b]{2}{*}{ Balance } & \\
\hline & & & & Urine & Feces & & & Urine & Feces & & \\
\hline $\begin{array}{l}2 \\
3 \\
2 \\
2 \\
2 \\
3 \\
3 \\
2 \\
3 \\
2 \\
2 \\
3 \\
3 \\
2 \\
2 \\
2 \\
2 \\
2\end{array}$ & $\begin{array}{c}31-33 \\
34-40 \\
41-52 \\
53-70 \\
71-82 \\
83-94 \\
95-106 \\
107-124 \\
125-142 \\
143-154 \\
155-172 \\
173-184 \\
185-196 \\
197-214 \\
215-232 \\
233-244 \\
245-256 \\
257-268 \\
269-280 \\
281-292\end{array}$ & $\begin{array}{l}g m . \\
0.615 \\
0.620 \\
0.739 \\
0.801 \\
0.788 \\
0.761 \\
0.824 \\
0.787 \\
0.816 \\
0.896 \\
0.833 \\
0.728 \\
0.626 \\
0.745 \\
0.747 \\
0.735 \\
0.800 \\
0.900 \\
0.886 \\
0.694\end{array}$ & $\begin{array}{c}\boldsymbol{g} \boldsymbol{m} . \\
\\
0.922 \\
\mathbf{0 . 9 2 2} \\
\mathbf{0 . 9 2 2} \\
\mathbf{0 . 9 2 2} \\
\mathbf{0 . 9 2 2} \\
\mathbf{0 . 9 2 2} \\
\mathbf{0 . 9 2 2} \\
\mathbf{0 . 9 2 2} \\
\mathbf{0 . 9 2 2} \\
\mathbf{0 . 9 2 2} \\
\mathbf{0 . 9 2 2} \\
\mathbf{0 . 9 2 2} \\
\mathbf{0 . 9 2 2} \\
\mathbf{0 . 9 2 2} \\
\mathbf{0 . 9 2 1} \\
\mathbf{0 . 9 2 2} \\
\mathbf{0 . 9 2 2} \\
\mathbf{0 . 9 2 2} \\
\mathbf{0 . 9 2 2}\end{array}$ & $\begin{array}{c}g m . \\
0.600 \\
0.674 \\
0.638 \\
0.608 \\
0.586 \\
0.564 \\
0.544 \\
0.507 \\
0.497 \\
0.475 \\
0.415 \\
0.351 \\
0.306 \\
0.284 \\
0.319 \\
0.294 \\
0.247 \\
0.211 \\
0.210 \\
0.223\end{array}$ & $\begin{array}{l}g m . \\
\\
0.714 \\
0.931 \\
0.864 \\
0.893 \\
0.825 \\
0.906 \\
0.866 \\
0.878 \\
0.962 \\
0.893 \\
0.888 \\
0.893 \\
0.828 \\
0.903 \\
0.802 \\
0.862 \\
0.698 \\
0.818 \\
0.746\end{array}$ & $\begin{array}{c}g m . \\
-0.466 \\
-0.647 \\
-0.550 \\
-0.557 \\
-0.467 \\
-0.528 \\
-0.451 \\
-0.453 \\
-0.515 \\
-0.386 \\
-0.317 \\
-0.277 \\
-0.190 \\
-0.300 \\
-0.175 \\
-0.187 \\
+0.013 \\
-0.106 \\
-0.047\end{array}$ & $\begin{array}{c}g m . \\
\\
1.675 \\
1.634 \\
1.659 \\
1.635 \\
1.664 \\
1.661 \\
1.651 \\
1.651 \\
1.647 \\
1.651 \\
1.647 \\
1.642 \\
1.653 \\
1.643 \\
1.659 \\
1.647 \\
1.647 \\
1.659 \\
1.634\end{array}$ & $\begin{array}{l}g m . \\
1.620 \\
1.550 \\
1.471 \\
1.398 \\
1.362 \\
1.355 \\
1.304 \\
1.292 \\
1.294 \\
1.262 \\
1.124 \\
1.173 \\
1.142 \\
1.206 \\
1.199 \\
1.049 \\
1.090 \\
1.052 \\
1.209 \\
1.188\end{array}$ & $\begin{array}{l}g m . \\
\\
0.506 \\
0.615 \\
0.555 \\
0.510 \\
0.492 \\
0.543 \\
0.511 \\
0.523 \\
0.550 \\
0.482 \\
0.468 \\
0.515 \\
0.462 \\
0.520 \\
0.448 \\
0.455 \\
0.400 \\
0.475 \\
0.410\end{array}$ & $\begin{array}{c}g m . \\
-0.381 \\
-0.452 \\
-0.294 \\
-0.237 \\
-0.183 \\
-0.186 \\
-0.152 \\
-0.166 \\
-0.165 \\
+0.045 \\
+0.006 \\
-0.015 \\
-0.015 \\
-0.076 \\
+0.162 \\
+0.102 \\
+0.195 \\
-0.025 \\
+0.036\end{array}$ & $\begin{array}{l}\text { Began } 2,800 \text { calories } \\
\text { Oscillating bed } \\
\text { Oscillating bed } \\
\text { Oscillating bed } \\
\text { Test. prop. } 25 \text { mgm. o.d. } \\
\text { Test. prop. } 25 \text { mgm. o.d. } \\
\text { Test. prop. } 50 \text { mgm. o.d. } \\
\text { T.p. } 25 \text { mgm.; estr.b. } 1.66 \mathrm{mgm} . \\
\text { T.p. } 25 \mathrm{mgm} \text {. estr.b. } 1.66 \mathrm{mgm} \text {. } \\
\text { T.p. } 25 \mathrm{mgm} \text {; estr.b. } 1.66 \mathrm{mgm} \text {. }\end{array}$ \\
\hline
\end{tabular}

TABLE XVI

Patient C. R.-Average daily urinary citric acid, and calcium and phosphorus balances

\begin{tabular}{|c|c|c|c|c|c|c|c|c|c|c|c|}
\hline \multirow{3}{*}{$\begin{array}{c}\text { No. } \\
\text { 6-day } \\
\text { periods }\end{array}$} & \multirow{3}{*}{$\begin{array}{l}\text { Days } \\
\text { after } \\
\text { onset }\end{array}$} & \multirow{3}{*}{$\begin{array}{c}\text { Citric } \\
\text { acid }\end{array}$} & \multicolumn{4}{|c|}{ Calcium } & \multicolumn{4}{|c|}{ Phosphorus } & \multirow[b]{3}{*}{ Remarks } \\
\hline & & & \multirow[b]{2}{*}{ Intake } & \multicolumn{2}{|c|}{ Output } & \multirow[b]{2}{*}{ Balance } & \multirow[b]{2}{*}{ Intake } & \multicolumn{2}{|c|}{ Output } & \multirow[b]{2}{*}{ Balance } & \\
\hline & & & & Urine & Feces & & & Urine & Feces & & \\
\hline $\begin{array}{l}2 \\
2 \\
3 \\
2 \\
3 \\
3 \\
2 \\
3 \\
2 \\
2 \\
1 \\
1 \\
1 \\
4 \\
3 \\
3 \\
2 \\
2\end{array}$ & $\begin{array}{c}50-55 \\
56-67 \\
68-79 \\
80-97 \\
98-109 \\
110-127 \\
128-145 \\
146-157 \\
158-175 \\
176-187 \\
188-199 \\
200-205 \\
206-208 \\
209-214 \\
215-238 \\
239-256 \\
257-274 \\
275-286 \\
287-298\end{array}$ & $\begin{array}{c}g m . \\
0.965 \\
0.893 \\
0.878 \\
0.795 \\
0.870 \\
0.812 \\
0.802 \\
0.857 \\
0.759 \\
0.592 \\
0.498 \\
0.462 \\
0.480 \\
0.538 \\
0.570 \\
0.537 \\
0.566 \\
0.434 \\
0.374\end{array}$ & $\begin{array}{c}\boldsymbol{g} m . \\
0.921 \\
0.921 \\
0.920 \\
0.920 \\
0.921 \\
0.920 \\
0.920 \\
0.916 \\
0.920 \\
0.921 \\
0.920 \\
0.895 \\
0.920 \\
0.920 \\
0.920 \\
0.920 \\
0.920 \\
0.920\end{array}$ & $\begin{array}{l}g m . \\
0.676 \\
0.710 \\
0.670 \\
0.687 \\
0.682 \\
0.627 \\
0.634 \\
0.637 \\
0.495 \\
0.362 \\
0.307 \\
0.306 \\
0.225 \\
0.283 \\
0.378 \\
0.405 \\
0.383 \\
0.373 \\
0.316\end{array}$ & $\begin{array}{l}\boldsymbol{g} m . \\
0.807 \\
0.743 \\
0.807 \\
0.806 \\
0.804 \\
0.827 \\
0.819 \\
0.856 \\
0.862 \\
0.798 \\
0.875 \\
0.867 \\
0.817 \\
0.880 \\
0.823 \\
0.838 \\
0.728\end{array}$ & $\begin{array}{c}g m . \\
-0.596 \\
-0.492 \\
-0.574 \\
-0.568 \\
-0.510 \\
-0.541 \\
-0.536 \\
-0.435 \\
-0.304 \\
-0.184 \\
-0.261 \\
-0.230 \\
-0.275 \\
-0.365 \\
-0.286 \\
-0.291 \\
-0.124\end{array}$ & $\begin{array}{l}g m . \\
1.332 \\
1.385 \\
1.336 \\
1.408 \\
1.399 \\
1.385 \\
1.449 \\
1.414 \\
1.420 \\
1.461 \\
1.359 \\
1.270 \\
1.399 \\
1.424 \\
1.432 \\
1.419 \\
1.420 \\
1.449\end{array}$ & $\begin{array}{l}g m . \\
1.220 \\
1.278 \\
1.199 \\
1.128 \\
1.154 \\
1.128 \\
1.206 \\
1.246 \\
1.012 \\
1.017 \\
1.010 \\
0.971 \\
0.787 \\
1.088 \\
1.095 \\
1.089 \\
1.084 \\
1.049 \\
0.942\end{array}$ & $\begin{array}{l}g m . \\
0.427 \\
0.409 \\
0.385 \\
0.418 \\
0.373 \\
0.401 \\
0.405 \\
0.411 \\
0.402 \\
0.393 \\
0.475 \\
\\
0.490 \\
0.438 \\
0.443 \\
0.411 \\
0.425 \\
0.359\end{array}$ & $\begin{array}{c}g m . \\
-0.373 \\
-0.223 \\
-0.177 \\
-0.164 \\
-0.102 \\
-0.222 \\
-0.202 \\
-0.009 \\
+0.001 \\
+0.058 \\
-0.087 \\
-0.179 \\
-0.109 \\
-0.100 \\
-0.076 \\
-0.054 \\
+0.148\end{array}$ & $\begin{array}{l}\text { Began } 2,000 \text { calories } \\
\text { Oscil., slow and rapid } \\
\text { Oscil., slow and rapid } \\
\text { Rapid rocking begun } \\
\text { Test. prop. } 25 \text { mgm. o.d. } \\
\text { Test. prop. } 25 \text { mgm. o.d. } \\
\text { Test. prop. } 50 \text { mgm. o.d. } \\
\text { Aspiration pneumonitis } \\
\text { Began sitting } \\
\text { Rapid rocking ended, day } 241 \\
\text { Began standing, day } 271 \\
\text { Test. prop. } 25 \text { mgm. o.d. }\end{array}$ \\
\hline
\end{tabular}

TABLE XVII

Patient J. W.-Average daily urinary citric acid, and calcium and phosphorus balances

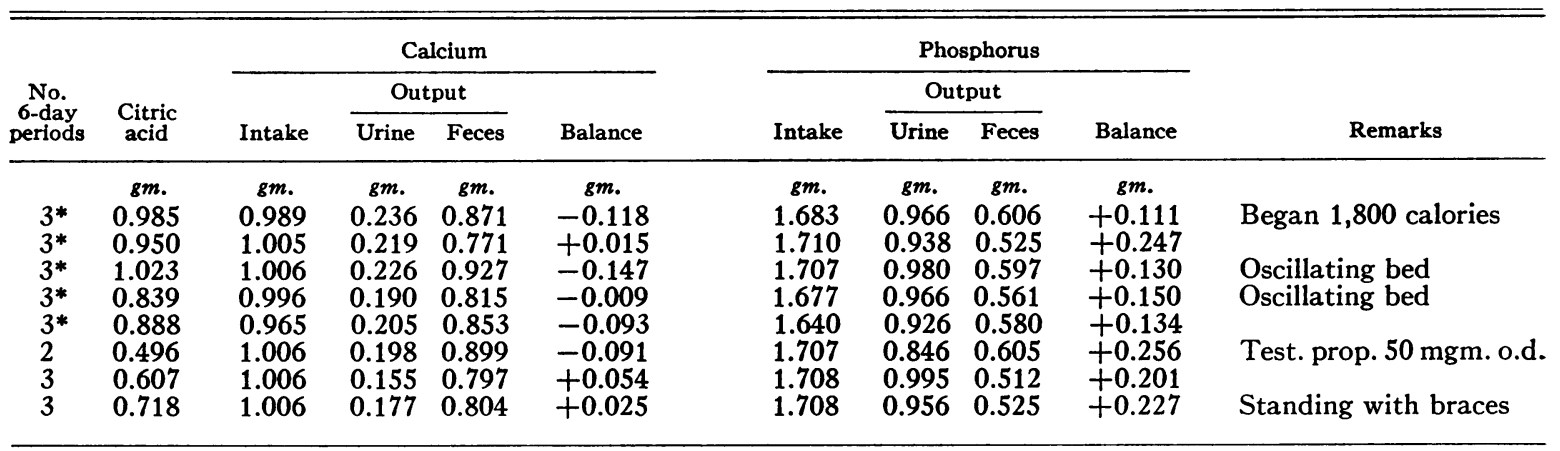

* Seven-day periods. 
TABLE XVIII

Patient R. V. K.-Average daily urinary citric acid, and calcium and phosphorus balances

\begin{tabular}{|c|c|c|c|c|c|c|c|c|c|c|}
\hline \multirow{3}{*}{ 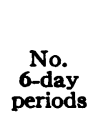 } & \multirow{3}{*}{$\begin{array}{l}\text { Citric } \\
\text { acid }\end{array}$} & \multicolumn{4}{|c|}{ Calcium } & \multicolumn{4}{|c|}{ Phosphorus } & \multirow[b]{3}{*}{ Remarks } \\
\hline & & \multirow[b]{2}{*}{ Intake } & \multicolumn{2}{|c|}{ Output } & \multirow[b]{2}{*}{ Balance } & \multirow[b]{2}{*}{ Intake } & \multicolumn{2}{|c|}{ Output } & \multirow[b]{2}{*}{ Balance } & \\
\hline & & & Urine & Feces & & & Urine & Feces & & \\
\hline & $g m$. & $\mathrm{gm}$. & $\mathrm{gm}$. & $\mathrm{gm}$. & $g m$. & $g m$. & $g m$. & $g m$. & $\mathrm{gm}$. & \\
\hline $\begin{array}{l}3 \\
3 \\
4 \\
3 \\
3 \\
2 \\
3 \\
4 \\
2 \\
2 \\
2 \\
2 \\
2 \\
3\end{array}$ & $\begin{array}{l}0.555 \\
0.592 \\
0.602 \\
0.687 \\
0.646 \\
0.776 \\
0.499 \\
0.525 \\
0.604 \\
0.488 \\
0.616 \\
0.578 \\
0.606 \\
0.613\end{array}$ & $\begin{array}{l}0.888 \\
0.888 \\
0.888 \\
0.888 \\
0.888 \\
0.836 \\
0.888 \\
0.888 \\
1.462 \\
1.449 \\
1.473 \\
1.468 \\
1.357 \\
1.454\end{array}$ & $\begin{array}{l}0.205 \\
0.183 \\
0.142 \\
0.126 \\
0.143 \\
0.131 \\
0.130 \\
0.108 \\
0.160 \\
0.141 \\
0.180 \\
0.180 \\
0.162 \\
0.163\end{array}$ & $\begin{array}{l}0.634 \\
0.651 \\
0.669 \\
0.582 \\
0.609 \\
0.558 \\
0.519 \\
0.548 \\
1.176 \\
1.083 \\
1.042 \\
1.016 \\
0.927 \\
0.903\end{array}$ & $\begin{array}{r}+0.049 \\
+0.054 \\
+0.077 \\
+0.180 \\
+0.136 \\
+0.147 \\
+0.239 \\
+0.232 \\
+0.126 \\
+0.225 \\
+0.251 \\
+0.272 \\
+0.268 \\
+0.388\end{array}$ & $\begin{array}{l}1.332 \\
1.330 \\
1.330 \\
1.330 \\
1.330 \\
1.272 \\
1.332 \\
1.330 \\
1.779 \\
1.758 \\
1.786 \\
1.780 \\
1.668 \\
1.769\end{array}$ & $\begin{array}{l}0.576 \\
0.611 \\
0.625 \\
0.621 \\
0.629 \\
0.615 \\
0.529 \\
0.666 \\
0.787 \\
0.783 \\
0.856 \\
0.712 \\
0.865 \\
0.840\end{array}$ & $\begin{array}{l}0.474 \\
0.476 \\
0.475 \\
0.463 \\
0.464 \\
0.442 \\
0.415 \\
0.430 \\
0.762 \\
0.662 \\
0.676 \\
0.626 \\
0.547 \\
0.582\end{array}$ & $\begin{array}{r}+0.282 \\
+0.243 \\
+0.230 \\
+0.246 \\
+0.237 \\
+0.215 \\
+0.388 \\
+0.234 \\
+0.230 \\
+0.313 \\
+0.254 \\
+0.442 \\
+0.256 \\
+0.347\end{array}$ & $\begin{array}{l}\text { Began 1,595 calories } \\
\text { Oscillating bed } \\
\text { Oscillating bed } \\
\text { Test. prop. } 50 \text { mgm. o.d. } \\
\text { Began } 1,938 \text { calories } \\
\text { Estr.b. } 1.66 \text { mgm. o.d. } \\
\text { Estr.b. } 1.66 \text { mgm.; t.p. } 50 \text { mgm. } \\
\text { Standing with braces }\end{array}$ \\
\hline
\end{tabular}

TABLE XIX

Lovett method examinations of representative muscle groups initially and at six months after onset in nine patients with anterior poliomyelitis*

\begin{tabular}{|c|c|c|c|c|c|c|c|c|c|c|c|c|c|c|c|c|}
\hline \multirow[b]{2}{*}{ Muscle function } & \multicolumn{2}{|c|}{ D. Q. } & \multicolumn{2}{|c|}{ M. O'M. } & \multicolumn{2}{|c|}{ D. A. } & \multicolumn{2}{|c|}{ J.C. } & \multicolumn{2}{|c|}{ R. W. } & \multicolumn{2}{|c|}{ F.S. } & \multicolumn{2}{|c|}{ C. $\mathbf{R}$. } & \multirow{2}{*}{$\frac{\text { J. W. }}{\text { Ini- }}$} & \multirow{2}{*}{$\frac{\text { R.V.K. }}{{\underset{\text { Ini- }}{\text { tialt }}}}$} \\
\hline & Ini- & $\begin{array}{l}\text { At } 6 \\
\text { mos. }\end{array}$ & $\begin{array}{l}\text { Ini- } \\
\text { tial }\end{array}$ & $\begin{array}{l}\text { At } 6 \\
\text { mos. }\end{array}$ & Ini- & $\begin{array}{l}\text { At } 6 \\
\text { mos. }\end{array}$ & Ini- & $\begin{array}{l}\text { At } 6 \\
\text { mos. }\end{array}$ & Ini- & $\begin{array}{l}\text { At } 6 \\
\text { mos. }\end{array}$ & $\begin{array}{l}\text { Ini- } \\
\text { tial }\end{array}$ & $\begin{array}{l}\text { At } 6 \\
\text { mos. }\end{array}$ & Ini- & $\begin{array}{l}\text { At } 6 \\
\text { mos. }\end{array}$ & & \\
\hline Chest-Intercostals & $\underset{\mathbf{L}}{\mathbf{L}} \mathbf{R}$ & $\begin{array}{ll}\mathbf{L} & \mathbf{R} \\
\mathbf{5} & \mathbf{5}\end{array}$ & $\begin{array}{ll}\mathbf{L} & \mathbf{R} \\
\mathbf{1} & 1\end{array}$ & $\begin{array}{ll}\mathbf{L} & \mathbf{R} \\
\mathbf{3} & \mathbf{3}\end{array}$ & $\begin{array}{ll}\text { I } & R \\
1 & 1\end{array}$ & $\begin{array}{ll}\mathbf{L} & \mathbf{R} \\
\mathbf{3} & \mathbf{3}\end{array}$ & $\begin{array}{ll}\mathbf{L} & \mathbf{R} \\
\mathbf{S} & \mathbf{S}\end{array}$ & $\begin{array}{ll}\mathbf{L} & \mathbf{R} \\
\mathbf{5} & \mathbf{5}\end{array}$ & $\begin{array}{ll}L & R \\
4 & 4\end{array}$ & $\begin{array}{ll}\mathbf{L} & \mathbf{R} \\
\mathbf{5} & \mathbf{5}\end{array}$ & $\begin{array}{ll}\mathbf{L} & \mathbf{R} \\
\mathbf{3} & \mathbf{3}\end{array}$ & $\begin{array}{ll}L & R \\
4 & 4\end{array}$ & $\begin{array}{l}\mathbf{L} \\
\mathbf{S} \\
\mathbf{R}\end{array}$ & $\begin{array}{ll}\mathrm{L} & \mathrm{R} \\
4 & 4\end{array}$ & $\begin{array}{ll}\mathbf{L} & \mathbf{R} \\
\mathbf{5} & \mathbf{5}\end{array}$ & $\begin{array}{ll}\mathbf{L} & \mathbf{R} \\
\mathbf{0} & \mathbf{0}\end{array}$ \\
\hline $\begin{array}{c}\text { Trunk-Flexion } \\
\text {-Extension }\end{array}$ & $\begin{array}{ll}2 & 2 \\
8 & 8\end{array}$ & $\begin{array}{ll}3 & 3 \\
5 & 5\end{array}$ & $\begin{array}{ll}1 & 1 \\
1 & 1\end{array}$ & $\begin{array}{ll}2 & 2 \\
4 & 4\end{array}$ & $\begin{array}{ll}1 & 1 \\
4 & 4\end{array}$ & $\begin{array}{ll}2 & 2 \\
4 & 4\end{array}$ & $\begin{array}{ll}2 & 2 \\
8 & 8\end{array}$ & $\begin{array}{ll}3 & 2 \\
4 & 4\end{array}$ & $\begin{array}{ll}3 & 3 \\
2 & 2\end{array}$ & $\begin{array}{ll}44 \\
44\end{array}$ & $\begin{array}{ll}1 & 1 \\
1 & 1\end{array}$ & $\begin{array}{ll}1 & 1 \\
3 & 3\end{array}$ & $\begin{array}{ll}1 & 1 \\
0 & 0\end{array}$ & $\begin{array}{ll}2 & 2 \\
0 & 0\end{array}$ & $\begin{array}{ll}1 & 1 \\
2 & 2\end{array}$ & $\begin{array}{ll}0 & 0 \\
1 & 0\end{array}$ \\
\hline $\begin{array}{l}\text { Hip_Flexion } \\
\text {-Extension }\end{array}$ & $\begin{array}{ll}2 & 2 \\
2 & 2\end{array}$ & $\begin{array}{ll}4 & 3 \\
8 & 4\end{array}$ & $\begin{array}{ll}2 & 2 \\
2 & 2\end{array}$ & $\begin{array}{ll}2 & 4 \\
4 & 4\end{array}$ & $\begin{array}{ll}1 & 1 \\
2 & 1\end{array}$ & $\begin{array}{ll}3 & 2 \\
3 & 1\end{array}$ & $\begin{array}{ll}0 & 1 \\
2 & 1\end{array}$ & $\begin{array}{ll}1 & 2 \\
3 & 2\end{array}$ & $\begin{array}{ll}2 & 3 \\
2 & 2\end{array}$ & $\begin{array}{l}44 \\
44\end{array}$ & $\begin{array}{ll}1 & 0 \\
2 & 1\end{array}$ & $\begin{array}{ll}1 & 1 \\
4 & 2\end{array}$ & $\begin{array}{ll}0 & 0 \\
\mathbf{S} & \mathbf{S}\end{array}$ & $\begin{array}{ll}0 & 0 \\
1 & 1\end{array}$ & $\begin{array}{ll}0 & 1 \\
0 & 0\end{array}$ & $\begin{array}{ll}0 & 0 \\
0 & 1\end{array}$ \\
\hline $\begin{array}{l}\text { Kneo-Flexion } \\
\text {-Extension }\end{array}$ & $\begin{array}{ll}2 & 2 \\
2 & 3\end{array}$ & $\begin{array}{ll}4 & 4 \\
4 & 5\end{array}$ & $\begin{array}{ll}2 & 3 \\
2 & 2\end{array}$ & $\begin{array}{ll}3 & 4 \\
2 & 4\end{array}$ & $\begin{array}{ll}3 & 1 \\
1 & 3\end{array}$ & $\begin{array}{ll}3 & 1 \\
2 & 4\end{array}$ & $\begin{array}{ll}1 & 1 \\
1 & 1\end{array}$ & $\begin{array}{ll}1 & 1 \\
1 & 1\end{array}$ & $\begin{array}{ll}2 & 2 \\
2 & 2\end{array}$ & $\begin{array}{ll}43 \\
44\end{array}$ & $\begin{array}{ll}1 & 0 \\
0 & 0\end{array}$ & $\begin{array}{ll}2 & 0 \\
0 & 4\end{array}$ & $\begin{array}{ll}\mathbf{8} & \mathbf{8} \\
0 & 0\end{array}$ & $\begin{array}{ll}0 & 0 \\
1 & 1\end{array}$ & $\begin{array}{ll}0 & 1 \\
0 & 0\end{array}$ & $\begin{array}{ll}0 & 0 \\
0 & 0\end{array}$ \\
\hline $\begin{array}{c}\text { Anklo-Plantar flexion } \\
\text { - Dorsal flexion }\end{array}$ & $\begin{array}{ll}2 & 3 \\
3 & 1\end{array}$ & $\begin{array}{ll}4 & 4 \\
4 & 1\end{array}$ & $\begin{array}{ll}2 & 2 \\
4 & 4\end{array}$ & $\begin{array}{ll}3 & 4 \\
3 & 5\end{array}$ & $\begin{array}{ll}3 & 1 \\
2 & 0\end{array}$ & $\begin{array}{ll}4 & 3 \\
4 & 0\end{array}$ & $\begin{array}{ll}1 & 1 \\
0 & 0\end{array}$ & $\begin{array}{ll}1 & 2 \\
1 & 1\end{array}$ & $\begin{array}{ll}3 & 3 \\
2 & 2\end{array}$ & $\begin{array}{ll}4 & 4 \\
4 & 4\end{array}$ & $\begin{array}{ll}3 & 0 \\
0 & 0\end{array}$ & $\begin{array}{ll}4 & 0 \\
0 & 0\end{array}$ & $\begin{array}{ll}0 & 1 \\
1 & 0\end{array}$ & $\begin{array}{ll}1 & 1 \\
1 & 1\end{array}$ & $\begin{array}{ll}0 & 2 \\
0 & 0\end{array}$ & $\begin{array}{ll}0 & 0 \\
0 & 0\end{array}$ \\
\hline $\begin{array}{c}\text { Shoulder_Abduction } \\
\text { Flexion }\end{array}$ & $\begin{array}{ll}5 & 5 \\
5 & 5\end{array}$ & $\begin{array}{ll}5 & 5 \\
5 & 5\end{array}$ & $\begin{array}{ll}2 & 2 \\
2 & 2\end{array}$ & $\begin{array}{ll}\mathbf{2} & \mathbf{3} \\
\mathbf{3} & \mathbf{3}\end{array}$ & $\begin{array}{ll}1 & 3 \\
2 & 3\end{array}$ & $\begin{array}{ll}34 \\
4 & 4\end{array}$ & $\begin{array}{ll}4 & 4 \\
4 & 5\end{array}$ & $\begin{array}{ll}\mathbf{5} & \mathbf{5} \\
\mathbf{5} & \mathbf{5}\end{array}$ & $\begin{array}{ll}\mathbf{0} & \mathbf{0} \\
\mathbf{0} & \mathbf{0}\end{array}$ & $\begin{array}{ll}1 & 0 \\
0 & 0\end{array}$ & $\begin{array}{ll}0 & 1 \\
0 & 1\end{array}$ & $\begin{array}{ll}\mathbf{3} & \mathbf{3} \\
\mathbf{1} & \mathbf{3}\end{array}$ & $\begin{array}{ll}1 & 0 \\
1 & 0\end{array}$ & $\begin{array}{ll}5 & 5 \\
4 & 3\end{array}$ & $\begin{array}{ll}4 & 4 \\
5 & 5\end{array}$ & $\begin{array}{ll}2 & 1 \\
2 & 1\end{array}$ \\
\hline $\begin{array}{l}\text { Elbow-Flexion } \\
\text { - Extension }\end{array}$ & $\begin{array}{ll}5 & 5 \\
5 & 5\end{array}$ & $\begin{array}{ll}\mathbf{5} & 5 \\
\mathbf{5} & 5\end{array}$ & $\begin{array}{ll}\mathbf{3} & \mathbf{3} \\
\mathbf{3} & \mathbf{3}\end{array}$ & $\begin{array}{ll}44 \\
45\end{array}$ & $\begin{array}{ll}2 & 4 \\
2 & 3\end{array}$ & $\begin{array}{l}45 \\
45\end{array}$ & $\begin{array}{ll}5 & 5 \\
4 & 4\end{array}$ & $\begin{array}{ll}\mathbf{5} & \mathbf{5} \\
\mathbf{5} & \mathbf{5}\end{array}$ & $\begin{array}{ll}\mathbf{0} & \mathbf{0} \\
\mathbf{0} & \mathbf{0}\end{array}$ & $\begin{array}{ll}2 & 0 \\
2 & 0\end{array}$ & $\begin{array}{ll}0 & 1 \\
0 & 1\end{array}$ & $\begin{array}{ll}1 & 1 \\
0 & 3\end{array}$ & $\begin{array}{ll}4 & 3 \\
2 & 0\end{array}$ & $\begin{array}{l}44 \\
41\end{array}$ & $\begin{array}{ll}5 & 5 \\
4 & 4\end{array}$ & $\begin{array}{ll}4 & 2 \\
2\end{array}$ \\
\hline Wrist-Flerion & 55 & 56 & $3 \mathbf{3}$ & 56 & 44 & 55 & 55 & 55 & 30 & 40 & 03 & 14 & 33 & 54 & $5 \mathbf{5}$ & 42 \\
\hline Fingers-Flexion & 55 & 55 & $3 \mathbf{3}$ & 55 & 55 & 55 & 55 & 55 & 40 & 40 & 13 & 24 & 33 & 44 & $5 \mathbf{5}$ & 42 \\
\hline $\begin{array}{l}\text { Urinary creatinine, } \\
\text { gm./day }\end{array}$ & 1.45 & 1.15 & 1.1 & 0.7 & 2.0 & 0.8 & 1.8 & 1.1 & 1.35 & 0.8 & 1.2 & 0.6 & 0.7 & 0.5 & 0.5 & 0.2 \\
\hline
\end{tabular}

* $K e y-B=$ Normal-Complete range of motion against gravity with full resistance. $4=$ Good - Complete range of motion against gravity with some resistance.

3 - Fair - Complete range of motion against gravity.

2 = Poor -Complete range of motion with gravity eliminated.

1 = Trace -Evidence of slight contractility.

$\mathbf{0}=$ Zero

+ Seven months after onset.

I Seventeen months after onset. 


\section{Case Summaries of Eleven Patients with Paralytic Acute Anterior Poliomyelitis}

\section{Case Summaries}

1. D.Q., 21-year-old male medical student (NYH No. 456347) ; onset of illness Sept. 15, 1948, with fever, headache and severe low back pain; admitted to New York Hospital (Infectious Disease Ward) Sept. 16. Physical examination revealed temperature of $38.4^{\circ} \mathrm{C}$. and slight stiffness of neck. Spinal fluid contained 208 white cells per mm. ${ }^{3}, 90$ per cent PMN leucocytes. An i.v. infusion of N-2-thiazolyl-phenol sulfonamide (DarvisulB) was instituted on the day of admission but was discontinued because of nausea, vomiting and retching after the patient had received 4 grams, i.e., one-twelfth of recommended dose. Onset of paralysis involving the lower extremities Sept. 18, third day after onset; muscle examination at maximal weakness is given in Appendix A, Table XIX. Patient's temperature reached normal on 6th day and remained below $37.5^{\circ} \mathrm{C}$. (rectal) thereafter. Paralysis of the urinary bladder required an in-dwelling catheter for 9 days; a resulting urinary infection was eradicated by sulfadiazine. Furmethide was employed effectively on 6 occasions in doses of 1 to $3 \mathrm{mgm}$. in order to augment bladder contraction. The patient was transferred to the Metabolism Ward on Sept. 29 (14th day after onset). Marked constipation and anorexia delayed institution of fixed dietary intake until 32nd day (Table I).

Hot pack therapy for 3 hours daily was begun on the 5th day after onset and continued for two and one-half months. Muscle re-education was begun on 19th day with the patient in bed, and from 54th day this therapy was given in the pool. From 79th day physical therapy was given in the gymnasium as well as in the pool. Increase in appetite required elevation of dietary intake on 57 th day from 2020 calories to 2400 , the protein and calcium intake remaining unchanged.

The patient began sitting in a chair on 69th day, began standing on 78th day, walking with "walker" on 99th day, with crutches on 105th day and with the aid of only a cane on 153rd day. Muscle examination at 6 months after onset is given in Appendix A, Table XIX.

The patient was discharged on 180th day and thereafter received physical therapy as an out-patient until readmission from 282 nd to 298 th days for further metabolic observations. The patient returned to medical school, completed his course and is now carrying out residency duties with occasional use of cane.

2. M.O'M., 21-year-old female secretary (NYH No. 553257) ; onset of illness Oct. 6, 1949, with sore throat, headache, nausea, vomiting, fever, and history of left chronic otitis media; admitted to New York Hospital (Infectious Disease Ward) Oct. 7. Physical examination showed temperature of $39.5^{\circ} \mathrm{C}$, perforated left ear drum draining purulent material, slight pharyngeal injection and moderate stiffness of neck. Spinal fluid contained 330 white cells per mm., 60 per cent lymphocytes. Onset of paralysis Oct. 9, third day after onset, with weakness of left deltoid, and following day weakness of intercostals and lower extremities. V.C. on 5th day was $1250 \mathrm{ml}$. Nasal oxygen given 5 th and 6th days. Temperature reached normal on 6th day and remained normal thereafter, except for minimal elevation 13th to 15 th days, reason not evident. Muscle examination at maximal weakness is given in Appendix A, Table XIX. The patient was transferred to the Metabolism Ward on Oct. 19, 13th day after onset. The patient was able to take a constant dietary intake beginning on the 25 th day (Table I).

Special procedures: M.O'M. was placed on a Sanders oscillating bed on the 8th day after onset. The bed oscillated 12 to 15 (average 14) hours daily through a total arc of 21 degrees ( 2 head down to 19 feet down). Oscillating time each day could not be extended because oscillation was too uncomfortable with patient on her side, due to tightness and pain in the shoulders; patient was able to sleep with bed oscillating when lying on back. Oscillation was discontinued on the 40th day after onset after a total period of 33 days.

Standard therapy and course: Hot pack therapy for 2 hours daily was begun on the 3rd day, was supplemented with hot tub 20 minutes daily beginning on the 6 th day; packs were continued for two and one-half months. Passive motion was begun on the 5th day. Muscle re-education was started on the 14th day in bed, from 71st day was given in the pool and from 92nd day in gymnasium as well as pool.

Ventilatory function remained stationary until the 20th day, then steadily improved, V.C. on the 29 th day being $1830 \mathrm{ml}$., on the 86th day $2075 \mathrm{ml}$. The patient began sitting in chair on 89th day, began standing 92nd day, walking with "walker" 101st day, with crutches 125th day, with one crutch 149th day and with one cane 167th day. Muscle examination 6 months after onset (time of discharge) is given in Appendix A, Table XIX.

The patient was discharged on 174th day and thereafter received physical therapy as an out-patient. Eleven months after onset the patient was re-employed parttime as a secretary and six months later resumed fulltime secretarial work.

3. D.A., 28-year-old male manager and owner of a woodworking business (NYH No. 478821); onset of illness Sept. 16, 1948, with severe occipital headache and fever which persisted and were later accompanied by low back pain and nausea. Onset of paralysis involving all four extremities Sept. 20, fourth day after onset. Admitted to New York Hospital (Infectious Disease Ward) September 21. Physical examination revealed temperature of 39.2C., and generalized pronounced muscle weakness as shown in Appendix A, Table XIX. Spinal fluid contained 128 white cells per mm. ${ }^{3}, 96$ per cent lymphocytes. Temperature reached normal on 9th day and remained normal from 11th day on. The patient was trans- 
ferred to the Metabolism Ward on Oct. 2nd (16th day after onset). A constant dietary intake was begun the following day (Table I).

Special procedures: Testosterone propionate $25 \mathrm{mgm}$. i.m. daily was given beginning on the 27 th day after onset. This dosage was continued for 18 days, then was raised to $25 \mathrm{mgm}$. b.i.d. for 12 days. Testosterone was discontinued on the 56th day, sesame oil $1 \mathrm{ml}$. b.i.d. i.m. being given for the next 12 days. Combined androgen and estrogen administration was begun on the 99th day with testosterone propionate $25 \mathrm{mgm}$. and Progynon-B (alpha estradiol benzoate) $1.66 \mathrm{mgm}$. (10,000 rat units), both i.m. daily. After 18 days Progynon-B dosage was doubled to $3.32 \mathrm{mgm}$. once daily, and this was given with testosterone for 6 days, both medications being discontinued on the 122nd day. After an interval of three months during which the patient made considerable improvement in muscle function and became able to walk with crutches and a long leg brace (detailed below), the patient was given Progynon-B $1.66 \mathrm{mgm}$. i.m. daily beginning on the 219th day; this dosage was continued for 18 days, then raised to $3.32 \mathrm{mgm}$. daily $(1.66 \mathrm{mgm}$. twice daily) for an additional 12 days and discontinued on the 248th day. Estrogen administration was accompanied by slight nipple tenderness and the development of 3 by 3 $\mathrm{cm}$. firm, flat, minimally tender tissue beneath the areolae.

Standard therapy and course: Hot pack therapy 4 to 6 hours daily was begun on the 7th day after onset and continued for two and one-half months. Muscle re-education was begun on the 18th day in bed, from the 75th day was given in the pool and from 81st day in gymnasium as well as pool. The patient also began sitting in chair on 81st day, began standing and walking in pool on 90th day. On 147th day dietary intake was reduced from 2800 calories to 2000 calories, nitrogen and calcium remaining the same, for the purpose of halting patient's perceptible increase in fat deposition. The patient began standing and walking a few steps with "walker" on 165th day, with crutches and long leg brace on 183rd day. Muscle examination at 6 months is given in Appendix A, Table XIX. At time of discharge (262nd day) patient was beginning to take few steps with crutches and without brace. At present patient walks with two canes and short dropfoot brace on right foot, works as a building contractor.

4. J.C., 39-year-old male advertising art director (NYH No. 549172); onset of illness August 17, 1949, with marked fatigue, mild abdominal and low back ache. Onset of paralysis involving chiefly the lower half of patient's body Aug. 19, second day after onset. Admitted to New York Hospital (Infectious Disease Ward) Aug. 22. Physical examination showed temperature $38.6^{\circ} \mathrm{C}$., slight stiffness of neck and muscle weakness as shown in Appendix A, Table XIX. Spinal fluid showed 52 white cells per mm., 68 per cent lymphocytes. The patient had urinary retention first 48 hours of hospital stay, requiring catheterization every 8 hours. Temperature reached normal on 8th day after onset and remained normal from 9th day on. The patient was transferred to Metabolism Ward Sept. 8 (22nd day after onset) and constant dietary intake was begun the following day (Table I).

Special procedure: J.C. was placed on a Sanders oscillating bed on the 14th day after onset. The bed was set to rock through an arc of 21 degrees (1 degree head down and 20 feet down), one and one-half minutes per cycle, and continued for a total of 16 to 18 hours (average 17) daily, being stopped only for meals, baths, bedpan, muscle re-education and briefly for application of hot packs. Oscillation was stopped on the 39th day after a total period of 26 days.

On the 70th day testosterone propionate $25 \mathrm{mgm}$. i.m. daily was begun, and this was continued for 36 days; testosterone administration was accompanied by an increase in the number of erections without nocturnal emissions and by transient acne. For 18 days during latter half of testosterone administration Progynon-B $1.66 \mathrm{mgm}$. i.m. daily was given also, accompanied by the transient appearance of tiny capillary hemangiomata over the anterior chest and upper abdomen and transient nipple soreness. Both hormones were discontinued on the 105th day, followed by a few days of fullness and tenderness of the areolae. After an interval of three months during which the patient improved to the point of beginning to stand between parallel bars (detailed below), testosterone propionate was again given, $25 \mathrm{mgm}$. i.m. daily for 36 days, beginning on the 190th day. Progynon- $B, 1.66 \mathrm{mgm}$. i.m. daily, was added during the last 18 days of testosterone. Slight tenderness about the areolae and firm, flat tissue 3 by $3 \mathrm{~cm}$. in area under the areolae was noted during the last 10 days of hormone administration and for approximately 10 days after both hormones were discontinued (225th day). During the last week of administration of the hormones the patient was beginning to take a few steps with long leg braces and crutches.

Standard therapy and course: Hot pack therapy 3 hours daily was begun on the day after admission, was supplemented with hot tub 20 min. daily beginning on the 20th day; prone and pin-on packs were continued for 3 months. Passive motion and muscle re-education were begun on 13th day; from the 58th day muscle re-education was given in the pool and from 133rd day in gymnasium as well as pool. Because of continuing weight loss and excellent appetite, dietary intake on 124th day was raised from 2400 to 2800 calories, the protein and calcium intake remaining unchanged. The patient began sitting in chair on 130th day, began standing and taking few steps in pool on 150th day, standing in gym 172nd day. Muscle examination 6 months after onset is given in Appendix A, Table XIX. Walking a few steps with long leg braces and "walker" was begun 214th day, and with crutches as well 220 th day, being very gradually increased during the eighth month.

Patient was discharged on 262nd day and thereafter received physical therapy as an out-patient. He returned to his office half-time shortly after discharge and since 1951 has been working full-time, chiefly from wheelchair.

5. R.W., 17-year-old male high school senior (NYH No. 522078); onset of illness Oct. 1, 1948, with headache, muscle aching, chilly sensations, fever and nausea. 
Onset of paralysis, involving chiefly patient's right arm, Oct. 2, first day after onset. Admitted to Grasslands Hospital, White Plains, N. Y., Oct. 2, where during next two days muscle weakness increased, involving all four extremities. Hot pack therapy 1 to 2 hours daily and passive exercise were instituted on 3rd day; by the end of first week some improvement was noted in muscles of right leg.

Patient was transferred to New York Hospital, Metabolism Ward, Oct. 19, 18th day after onset. Physical examination revealed normal vital signs and pronounced generalized muscle paralysis as shown in Appendix A, Table XIX. A constant dietary intake was begun on 23rd day (Table I).

Special procedure: Testosterone propionate $25 \mathrm{mgm}$. i.m. daily was begun on the 28 th day after onset and continued for 30 days; sesame oil $1 \mathrm{ml}$. i.m. was then given during the next 6 days. During testosterone administration there was a slight increase in a mild acneform folliculitis over the anterior chest wall but no acne on face, edema or other clinical effects. On the 106th day after onset testosterone propionate $25 \mathrm{mgm}$. i.m. and Progynon-B $1.66 \mathrm{mgm}$. (10,000 rat units) i.m. daily were begun and administered for 18 days; during this administration the patient had minimal nipple soreness for the last two days but no other clinical effects. Progynon-B alone, $1.66 \mathrm{mgm}$. i.m. daily, was given for 18 days beginning on the 190th day; at this time the patient was walking well without support. On the final day of Progynon-B administration the patient noted slight tenderness of the nipples, and firm, flat tissue $(2 \mathrm{~cm}$. in diameter) could be palpated below each areola. T'estosterone propionate alone, $25 \mathrm{mgm}$. i.m. daily, was given for 24 days beginning on the 232 nd day; only symptom or sign noted was difficulty starting urinary stream upon awakening in the morning without any increased tendency to erections.

Standard therapy and course: Hot pack therapy, 4 hours daily, was continued for the first two and one-half months. Muscle re-education in bed was begun 24th day, from 87 th day was given in pool and from 152nd day in gymnasium as well as in pool. Patient began sitting in chair, right arm in airplane splint, on 84th day, began standing and walking in pool on 94th day. Dietary intake was raised from 2000 to 2400 calories on 94th day, protein and calcium intake remaining unchanged. $\mathrm{Pa}$ tient began walking, without need for support, on 154th day; at this time sitting in chair was increased from 2 to 6 hours daily. By 172nd day progressive increase in activity required increase in constant dietary intake to 2800 calories, protein and calcium intake being maintained at original level.

Muscle examination at 6 months after onset (Appendix A, Table XIX), indicated progressive improvement in muscles of lower extremities and increasing facility in use of left hand, without change in right upper extremity. Patient was discharged on 281st day to continue physical therapy as an out-patient at a hospital near his home. Patient completed high school and at present is employed at office work.
6. F.S., 20-year-old male student (NYH No. 491299); onset of illness Sept. 23, 1947, with headache, stiff neck, pain in back, fever, and loose stools. Onset of paralysis, chiefly involving the legs, Sept. 26, third day after onset. Admitted to Grasslands Hospital, White Plains, N. Y., Sept. 27. Spinal fluid showed 164 white cells per mm.", 94 per cent lymphocytes. Extent of paralysis increased to involve all four extremities; paresis of urinary bladder requiring catheterization was present from 6 th to 14 th day. Hot pack therapy was begun shortly after admission.

Patient was transferred to New York Hospital, Metabolism Ward, Oct. 22, 29th day after onset. Physical examination revealed normal vital signs and marked, extensive muscle paralysis as shown in Appendix A, Table XIX. Constant dietary intake was begun on 31st day (Table I).

Special procedures: F.S. was placed on a Sanders oscillating bed on the 53rd day after onset. Arc of excursion of the bed was 19 degrees during first 20 days of oscillation then, by transfer to another bed, was 21 degrees ( 1 degree head down and 20 degrees feet down) with one complete cycle every one and one-half minutes. Oscillation was for 21 hours daily. At foot-down end of excursion of bed, blood pressure cuff under heels showed an increase in pressure of $70 \mathrm{~mm}$. $\mathrm{Hg}$ over that in the horizontal position. Oscillation during sleep was well tolerated. Edema of ankles was noted approximately two weeks after oscillation was begun. Oscillation was discontinued after 30 days, and edema subsided within three days. The patient was again placed on an oscillating bed on the 107th day, the arc of excursion being 1.5 degrees head down to 18 degrees feet down. Slight ankle edema again occurred during oscillation and subsided three days after oscillation was stopped. This second phase of oscillation extended for 18 days.

On the 155th day testosterone propionate $25 \mathrm{mgm}$. i.m. daily was begun. This dosage was continued for 30 days; during the next 12 days $25 \mathrm{mgm}$. was given b.i.d. and then androgen was discontinued. During testesterone administration slight ankle edema occurred, and the patient noted increased beard growth, libido and more frequent erections and nocturnal emissions. Combined androgenestrogen was given for 36 days beginning at the 233rd day; the daily dosage throughout was $25 \mathrm{mgm}$. of testosterone propionate and $1.66 \mathrm{mgm}$. of Progynon-B. Midway during the administration of these hormones the patient had slight nipple soreness for two days, but no other clinical effects were noted.

Standard therapy and course: Hot pack therapy, 6 to 8 hours daily, was continued for the first two and one-half months. Passive exercises and muscle re-education in bed were begun 35th day after onset, from 143rd day were given in pool. Improvement in muscle function was slow, as indicated in muscle examination at 6 months (Appendix A, Table XIX). Metabolic observations were discontinued after 294 days, at which time the patient was transferred to a general medical ward for continuation of physical therapy. Patient was then mobilized to chair and began standing in pool. Ultimate rehabilitation of pa- 
tient has been to wheelchair from which he operates a physicians' call service.

7. C.R., 18-year-old male high school student (NYH No. 493453); onset of illness Sept. 17, 1947, with back pain, nausea, headache, stiffness of neck and fever. Onset of paralysis, initially involving left leg, Sept. 18, first day after onset. Admitted to Willard Parker Hospital, New York City, Sept. 18. Spinal fluid showed 350 white cells per mm.", "mostly mononuclears." Muscle weakness progressed to involve all four extremities, urinary bladder to the extent that catheterization was twice required on 3rd day and the respiratory muscles so that on 5th day patient was placed in tank respirator. Time out of respirator was gradually increased so that after 2 weeks he was out 30 to 45 minutes every 4 hours. Respirator was discontinued altogether on 31st day; total number of days in respirator, 26. Duration of fever was 10 days. Lay-on hot packs were given approximately 4 hours daily and muscle re-education begun during stay at Willard Parker Hospital. During 4th to 7th weeks gradual improvement in arms and hands occurred.

Patient was transferred to New York Hospital, Metabolism Ward, Nov. 4, 48th day after onset. Physical examination revealed normal vital signs except for respiratory rate of $28 / \mathrm{min}$. Muscle examination reported in Appendix A, Table XIX indicates the extreme extensive muscle paralysis. Pulmonary ventilation was carried on by the action of sternocleidomastoid muscles with assistance of diaphragm, which, on fluoroscopy, moved $1 \mathrm{~cm}$. bilaterally (not paradoxical); chest cage was rigid, intercostals spastic. Vital capacity $500 \mathrm{ml}$. (serum $\mathrm{CO}_{2}$ combining power 61 vol. per cent). Urine was normal except for 10 to 20 white cells/HPF cent. and numerous bacteria ; urine culture, $E$. coli. Sulfadiazine $1 \mathrm{gm} .4$ i.d. with sodium bicarbonate $1 \mathrm{gm} .4$ i.d. for 6 days, $62 \mathrm{nd}$ to 67 th, cleared urinary infection. Constant dietary intake (Table I) was begun on 50th day.

Special procedures: The patient was placed on a Sanders oscillating bed on the 80th day after onset. The daily period on this bed averaged 14 hours $(6$ p.m. to $8: 30$ a.m.) ; arc of excursion was 20 degrees (2 degrees head down and 18 degrees feet down) with one complete cycle every one and one-half minutes. The patient slept well while the bed was oscillating. The same day, because of ventilatory insufficiency with diminished diaphragm excusion, the patient was placed on a rapidrocking bed, rate $16 / \mathrm{min}$., total arc 24 degrees (12 degrees each side of horizontal), 7 to 8 hours daily; the head of the bed was elevated so that the patient's head did not fall below the horizontal. Both forms of oscillation were discontinued after 30 days, on the 109th day. Rapid rocking only was resumed on the 128th day at the same arc and rate but for 12 hours daily; after 114 days during which time other procedures were carried out, rapid rocking was discontinued on the 241st day. Vital capacity at this time was $2400 \mathrm{ml}$.

Testosterone propionate, $25 \mathrm{mgm}$. i.m. daily, was begun on the 158th day. After 30 days the dosage was raised to $25 \mathrm{mgm}$. b.i.d. which was given for the next 12 days. Slight puffiness of ankles occurred approximately two weeks after start of therapy, but no other clinical effects were noted. Testosterone propionate, $25 \mathrm{mgm}$. i.m. daily, was again given beginning at the 287th day for 12 days; no clinical effects were noted.

Standard therapy and course: Hot pack therapy, 6 to 8 hours daily, was resumed on 51st day and, because of extreme muscle tightness, was continued for four and one-half months, to 139th day. Muscle re-education in bed was resumed on 52nd day, from 146th day was given in pool and from 239th day in gymnasium as well as pool. The slow improvement in muscle function is indicated in the muscle examination at 6 months (Appendix A, Table XIX).

On 206th day after onset, following immersion in pool, patient had malaise, nausea, temperature elevation to $39.2^{\circ} \mathrm{C}$. and slight suppression of breath sounds at right base in posterior axillary line without evidence of infiltration by $\mathrm{X}$-ray. Fifty thousand units aqueous penicillin q. $3 \mathrm{~h}$. for 72 hours resulted in prompt clearing of signs. Duration of temperature elevation was 36 hours without evident effect upon excretion of metabolic constituents.

Patient began sitting in chair and standing in pool on 239th day. Patient stood in braces on ward on 271st day and was gradually able to shift weight from one leg to other while standing for 20 to 30 minutes daily. $\mathrm{Pa}$ tient was discharged on 301st day for two-week leave of absence, then readmitted to a general medical ward for continued physical therapy. Ultimate rehabilitation has been chiefly wheelchair.

8. J.W., 20-year-old housewife and mother (NYH No. 466391) ; onset of illness June 27, 1946, with backache, pains in legs, fatigue and fever. Onset of paralysis, chiefly involving legs, June 30, 3rd day after onset. Admitted to St. Mary's Hospital, West Palm Beach, Florida, where muscle weakness increased to involve abdomen, back, left shoulder and hand; for two weeks function of urinary bladder and intestinal tract was impaired so that catheterization and enemas were required. Hot pack therapy, 2 to 4 hours daily, and muscle re-education were given throughout patient's 11-week stay in St. Mary's Hospital. Patient began sitting in chair 9 weeks after onset.

Patient was transferred to New York State Reconstruction Hospital, West Haverstraw, N. Y., October 7, 102 nd day after onset. Muscle re-education in pool was resumed and walking in pool with braces and walker was begun 4 weeks later.

Patient was transferred to New York Hospital, Metabolism Ward, January 19, 1947, 206th day (7 months) after onset. Physical examination revealed normal vital signs and rather marked muscle paralysis of lower extremities as indicated in muscle examination given in Appendix A, Table XIX. X-rays of the skeleton revealed osteoporosis of the pelvis and of the ends of the long bones. Constant dietary intake was begun on 212th day (Table I).

Special procedures: The patient was placed on a Sanders oscillating bed on the 258th day. Arc of excursion was 2 degrees head down to 15 degrees feet down, 
cycle 2 minutes, 17 to 18 hours per day. Oscillation was discontinued after 42 days. The patient was comfortable and slept well on the bed.

Testosterone propionate $25 \mathrm{mgm}$. i.m. b.i.d. (total 50 mgm. daily) was given for 12 days beginning at the 321st day; no clinical effects were noted.

Standard therapy and course: Muscle re-education in gymnasium was begun on admission. Patient sat in chair one and one-half hours daily until 351st day when time sitting was increased and patient began standing and walking in long leg braces in "walker." Patient was discharged on 370th day to continue physical therapy as an out-patient.

9. R.V.K., 19-year-old female student nurse (NYH No. 460945); onset of illness July 9, 1945, with fever, muscular aching and weakness. Onset of paralysis involving all four limbs, July 10 , on which day she was admitted to Willard Parker Hospital, New York City. Degree of paralysis increased and on 4th day after onset patient was placed in tank respirator in which she remained for 17 days. Additional treatment in Willard Parker Hospital included hot packs and hot tub 15 minutes daily. By 6 weeks after onset patient could move head from side to side and move left arm by crawling with fingers.

On August 21, 43rd day after onset, patient was transferred to New York State Reconstruction Hospital, West Haverstraw, New York, where hot packs were continued for an additional 5 weeks. Muscle re-education in bed and in pool was given daily with slow improvement in muscle function, initially in the left arm, later neck flexors, right arm and leg. In September, 1946, 14 months after onset, patient began sitting in chair 2 hours daily.

Patient was transferred to New York Hospital, Metabolism Ward, November 17, 1946, 496th day (17 months) after onset. Physical examination revealed normal vital signs, marked malnutrition (body weight 28.7 $\mathrm{Kg}$.) and extensive muscle paralysis as indicated in muscle examination given in Appendix A, Table XIX. $\mathrm{X}$-rays of the skeleton revealed osteoporosis of the pelvis and long bones, more pronounced at the ends of the latter. Intravenous pyelography revealed no evidence of urinary tract calculi. Since the patient at rare intervals had slight regurgitation into the nose, fluoroscopic examination of the esophagus was performed but was negative. Fluoroscopy of the chest revealed an elevated and fixed right diaphragm. Constant dietary intake (Table I) was begun on 503rd day.

Special procedures: R.V.K. was placed on a Sanders oscillating bed on the 543rd day after onset. Oscillation was continued for 42 days. The excursion was 23 degrees (head down 3 degrees, feet down 20 degrees), the rate one cycle every 150 seconds (excessive vibration at more rapid rate) and the daily period eighteen and onehalf hours. During oscillation the patient slept better than previously and stated that her feet were always warm; one week after cessation of oscillation patient complained of coldness of feet.
On the 615th day testosterone propionate $25 \mathrm{mgm}$. b.i.d. (total $50 \mathrm{mgm}$. daily) was begun and was given for 18 days. Slight huskiness of the voice and a small amount of facial acne appeared 13 days after the beginning of testosterone administration.

Progynon-B, 5000 rat units, i.m. b.i.d. (total $1.66 \mathrm{mgm}$. daily) was begun on the 671st day and continued for 24 days. During the final 12 days of estrogen administration testosterone propionate, $25 \mathrm{mgm}$. i.m. b.i.d. (total $50 \mathrm{mgm}$. daily), was also given. On the final day of combined hormone administration slight huskiness of the voice was noted; this subsided in three days.

Standard therapy and course: Muscle re-education and streching in bed and in gymnasium were begun on entry. There was slight improvement in muscle function, chiefly in the left arm, during patient's 8-month stay. R.V.K. sat in chair one and one-half hours daily until last 3 weeks of her stay (719th day) when time sitting was increased gradually to 6 hours and she began standing in aluminum long leg braces 5 to 15 minutes once a day. $\mathrm{Pa}$ tient was discharged home on 736th day after onset.

10. R.Wil., 19-year-old female artist (NYH No. 552829) ; onset of illness Oct. 12, 1949, with severe headache, backache, weakness, dizziness, stiff neck, and fever $\left(\mathrm{T}-102^{\circ} \mathrm{F}\right.$.). Onset of paralysis the following day involving both legs. Admitted to City Hospital, New York City, Oct. 13, where L.P. was performed; spinal fluid slightly cloudy, Pandy,+ 200 cells. Transferred to New York Hospital Oct. 14. Patient had diabetes mellitus known for 2 years, taking 25 units of protamine zinc insulin daily. Physical examination showed muscle weakness which was severe of all leg muscles ( $O$ to $P$ ), moderately severe of trunk and mild of arm muscles (F to $G$ ). An indwelling catheter in the urinary bladder was required for four days. V.C. was $1500 \mathrm{ml}$. on Oct. 14, thereafter rose toward normal levels. The entire study was carried out on the Infectious Disease Ward where 24-hour urine collections, daily dietary survey and regulation of caloric, protein and calcium intake levels were begun on the 4th day after onset.

Special procedure: The patient was placed on a Sanders oscillating bed on the 7th day after onset. Arc of excursion was 21 degrees ( 1 degree head down and 20 feet down), and time for complete cycle was one and onehalf minutes; daily time period oscillating varied widely but averaged 10 hours. Oscillation was discontinued on the 23rd day after a total period of 17 days.

Standard therapy and course: Pin-on hot packs, supplemented by hot tubs, were given 8 hours daily from the 4th day. Muscle re-education was started on the 16th day in bed, was given in the pool from the 37th day. The patient's diabetes was well controlled on $\mathbf{4 0}$ units of regular and 20 units of protamine zinc insulin daily given in the same syringe. On the 51st day urine collections were discontinued and the patient began sitting in a wheelchair. At this time shoulder girdle and arm muscles had improved generally to a rating of good; trunk and leg muscles were unchanged. Shoulder and arm muscles 
continued to improve. During the 5th month after onset the patient was transferred to another hospital.

11. J.L., 21-year-old housewife (NYH No. 455795); onset of illness Oct. 1, 1948, with headache, nausea, muscle aching, stiff neck and fever $\left(\mathrm{T}-103^{\circ} \mathrm{F}\right.$.). Weakness of the left arm was noted on day of onset, and on the following day weakness of right arm and neck muscles with slight difficulty in breathing and swallowing. On the 5th day the patient was admitted to a local hospital where spinal fluid showed 67 cells, 90 per cent lymphocytes, and hot pack therapy was begun. On the 6th day the patient was transferred to the New York Hospital. Physical examination revealed normal vital signs except for a respiratory rate ranging from 20 to $28 / \mathrm{min}$. There was extreme weakness ( $O$ to $T$ ) of all neck, shoulder, arm and intercostal muscles; trunk and abdominal muscles were rated fair and the lower extremities normal. Speech was slightly nasal and the V. C. $550 \mathrm{ml}$. Nasal oxygen was given for 5 days and rapid rocking from the 9th to the 17th day. On the 12th day 24-hour urine collections, daily dietary survey and an effort at regu- lating the patient's caloric, protein and calcium intake levels were begun; the entire study was carried out on the Infectious Disease Ward.

Special procedure: The patient was placed on a Sanders oscillating bed on the 24th day after onset. Arc of excursion was 18 degrees (1 degree head down and 17 feet down), and time for complete cycle one and one-half minutes; daily time period oscillating averaged 16 hours. Oscillation was discontinued on the 44th day after a total period of 21 days.

Standard therapy and course: Hot pack therapy was continued for the first two months. Passive motion and muscle re-education were begun in bed on the 17th day and from the 31 st day were given in the pool. The patient began standing in the pool with water to axillae on the 35th day, began sitting in a chair 60th day, and began walking (unsupported) on the 64th day. Ventilatory capacity improved gradually and V. C. was $1000 \mathrm{ml}$. on 64th day. Patient was discharged home on the 71st day and thereafter received physical therapy as an outpatient. 